\title{
RITKÁBB VÍZIVADFAJOK ELŐFORDULÁSA MAGYARORSZÁGON A 2006/2007-ES VONULÁSI IDÉNYBEN
}

\author{
THE OCCURRENCE OF RARE WATERFOWL SPECIES IN HUNGARY DURING THE \\ 2006/2007 MIGRATION
}

\section{Hadarics Tibor}

Magyar Madártani és Természetvédelmi Egyesület, Hungarian Ornithological and Natur Conservation Society H-9400 Sopron, Wälder József utca 4. D/2.

Magyar Vízivad Kutató Csoport, Nyugat-magyarországi Egyetem Vadgazdálkodási és Gerinces Állattani Intézet Hungarian Waterfowl Research Group, Institute of Wildlife Management and Vertebrate Zoology, University of West-Hungary, H-9400 Sopron, Bajcsy-Zsilinszky u. 4., Hungary

\section{BEVEZETÉS}

A szervezett vízivad szikronmegfigyelések Magyarországon 1955 óta folynak. Kezdetben csak a legjelentősebb vízivadas területekről gyüjtötték az adatokat. A megfigyelések a Magyar Madártani és Természetvédelmi Egyesület megalakulásával váltak országossá. A megfigyelők által beküldött adatok rendszeresen eljutottak az európai feldolgozó központba, Slimbridge-be, de itthon alig kerültek feldolgozásra, sőt még közlésre sem. Az 1986 szeptembere és 1992 decembere közötti adatok táblázatos formában rendszeresen megjelentek ugyan az Egyesület által kiadott Oxyura címü híradóban, de ez csupán az adatok tényszerü közlése volt, különösebb elemzések nélkül. Egyedül vadludak vonatkozásában születtek feldolgozások (FARAGÓ, 1995, 1996, 1998b, 1999b, 2001b, 2002b, 2002c; FARAGÓ \& JÁNOSKA, 1996). Az 1996/97-es szezonról már részletes dolgozat jelent meg, amely - a vadludak kivételével - a felmérésbe bevont fajok teljes körét (búvárok, vöcskök, úszó- és bukórécék, bukók) feldolgozza (FARAGÓ, 1998a). Az 1997/98-as (FARAGÓ, 1999a, 1999b), az 1998/99-es (FARAGÓ, 2001a, 2001b) az 1999/2000-es (FARAGÓ \& GOSZTONYI, 2002; FARAGÓ, 2002b), a 2000/2001-es (FARAGÓ, 2002a, 2002c), a 2001/2002-es (FARAGÓ \& GOSZTONYI, 2003a, 2003b), a 2002/2003as (FARAGÓ, 2005 a, 2005b), a 2003/2004-es (FARAGÓ, 2006a, 2006b), a 2004/2005-ös (FARAGÓ, 2007a, 2007c), a 2005/2006-os (FARAGÓ, 2007b, 2007d) és a 2006/2007-es szezon szinkronmegfigyeléseinek részletes eredményeit feldolgozó közlemények már szintén napvilágot láttak (FARAGÓ, 2008a, 2008b). A ritkább vízivadfajok 1997/98-as (HADARICS, 2000), 1998/99-es (HADARICS, 2003a), 1999/2000-es (HADARICS, 2003b), 2000/2001-es, 2001/2002-es és 2002/2003-as (HADARICS, 2013), 2004/2005-ös (HADARICS, 2016a), valamint 2005/2006-os idénybeli előfordulásairól megjelent közlemények (HADARICS, 2016b) e fajoknak már nemcsak a szinkronnapokon tett megfigyeléseit, hanem valamennyi ismertté vált hazai előfordulását tartalmazza.

\section{ANYAG ÉS MÓDSZER}

A szinkron megfigyelések minden hónap 15-éhez közelebb eső hétvégén történnek. A gyakori, és hazánkon nagy tömegben átvonuló fajok vonulásdinamikája szempontjából ez a havonkénti felmérés elégnek látszik, bár nyilván gyakoribb adatgyüjtéssel pontosabb képet kaphatnánk, hiszen elképzelhető, hogy egy-egy faj vonulásának csúcspontja éppen a két felmérés közötti időszakra esik. Aki gyakran jár terepre az tudhatja, hogy sokszor napok alatt is jelentős mennyiségi változások lehetnek a madarak számában.

A hazánkban ritkábban megjelenő madárfajok vonulásdinamikája a havi egy felméréssel már nem rajzolódik ki teljesen, hiszen minél ritkább egy faj, annál kisebb a valószínűsége, hogy éppen a szinkronnapokon kerül szem elé. Ezért az alábbi írásban közreadjuk a Magyarországon ritka, vagy közepesen ritka fajok valamennyi adatát. Természetesen ezek az adatsorok a gyakori fajok szinkronadataival nem vethetők össze, de az adott madárfaj vonulásáról hübb képet rajzolnak.

A ritka és közepesen ritka madárfajok adatainak gyüjtése a www.birding.hu honlap segítségével zajlik. A honlapra egy egyszerü regisztráció után bárki fel tudja tölteni megfigyeléseit, az adatokat a honlap fenntartói egy adatbázisban tárolják, ahonnan azok különböző szempontok szerint leválogathatók. A honlap 2004 májusában indult, így a 2004/2005-ös és az az követő idényeket gyakorlatilag már teljes egészében lefedi, ami azt jelenti, hogy a ritkább vízivadfajok előfordulási adatait fajonként szerkesztett formában, elsősorban a www.birding.hu honlapra feltöltött adatokra támaszkodva évenként folyamatosan közzé tudjuk tenni. A www.birding.hu honlapról származó adatokat - a Magyarországon nagyon ritkán megjelenő madárfajok 
esetében - kiegészítettem az MME Nomenclator Bizottság éves jelentéseiből származó olyan adatokkal, amelyeket a megfigyelök a www.birding.hu honlapra különböző okokból nem töltöttek fel. Sajnos az ország bizonyos jelentős vízimadaras élöhelyeiről (pl. a Hortobágy térségéböl) viszonylag kevés adat kerül be a birding.hu adatbázisába, mert az e területeken tevékenykedő egyes megfigyelök úgy tünik nem érzik szükségét annak, hogy adataikat közzétegyék, azokat másokkal megismertessék.

Amennyiben egy madár huzamosabb ideig tartózkodik valamely területen, akkor több egymás utáni vagy közel egymás utáni adat is vonatkozhat ugyanarra a példányra (az adatokat ugyanis csak akkor vontam össze, ha egymás utáni napokon történő megfigyelések nagy valószínüséggel ugyanarra a példányra vagy példányokra vonatkoznak, egyéb esetekben csak a tényleges megfigyelési napokat közöljük). Ha vélhetöen ugyanazon példány két megfigyelése között eltelt néhány olyan nap, amikor nincs a madárról adat, akkor valószínűsíthető, hogy azokon a napokon nem járt megfigyelő a területen, esetleg elkerülte a figyelmet a madár, de az is elképzelhető, hogy éppen átmenetileg egy másik területen (pl. egy másik közeli halastavon) tartózkodott.

A megfigyelt madarak korára és ivarára minden esetben a megfigyelők által megadottakat használom, ezért elöfordulhat, hogy egy madár egyszer $a d$.-nak máskor $j u v$.-nak van határozva (de persze előfordulhat az is, hogy két különböző madárról van szó), ugyanis a különbözö megfigyelök sokszor eltérően határozzák, illetve ítélik meg ugyanazon példány korát.

Egyes madárfajok előfordulási adatai a Nomenclator Bizottság által hitelesítendők. Az adat hitelesített vagy még nem bírált (és így nem is hitelesített voltára) a szöveges részben utalok. A Nomenclator Bizottság által elutasított adatokat a felsorolásból kihagytam. A még nem bírált adatokat a dátum után tett csillaggal (*) jelzem, ezeknél az adatoknál a megfigyelők nevét nem adom meg.

\section{EREDMÉNYEK}

\section{1. Északi búvár (Gavia stellata)}

Öszi vonulása során az első példányok október végén jelentek meg. Többnyire a nagyobb folyókon (pl. Duna) és tavakon (Balaton, Tisza-tó), illetve egyéb kisebb tavakon, halastavakon, bányatavakon figyelték meg. A legtöbb adat novemberből és decemberből származik. Az őszi, a téli és a kora tavaszi időszakban mindig téli tollazatú ad. vagy juv. (1y) példányok kerültek szem elé. A madarak többnyire egyesével fordultak elő, néha két vagy három példányt figyeltek meg, de január utolsó harmadában a Balatonon öt, illetve hét példányt is megfigyeltek egyszerre (2007. január 20. Fenékpuszta 7 pld., 2007. január 20. Tihany-Gödrös 5 pld., 2007. január 21. Siófok 7 pld.). Januárban még viszonylag sok alkalommal látták, a tobábbi hónapokban csökkent az adatok száma, áprilisban már csak a kiskunlacházi bányatavkon, május elején pedig a Dunán (Dunaszentbenedek) figyelték meg (utóbbi esetben egy nászruhás példányt).

\begin{tabular}{|c|c|c|}
\hline 2006.10 .22 . & Balatonfüred, Balaton & 1 \\
\hline 2006.10 .31 & Fenékpuszta, Balaton & 1 juv. \\
\hline 2006.11 .01 . & Abádszalók, Tisza-tó (Abádszalóki-öböl) & 1 juv. \\
\hline 2006.11 .03 . & Abádszalók, Tisza-tó (Abádszalóki-öböl) & 1 juv. \\
\hline 2006.11 .04$. & Tömörkény, Csaj-tó & 1 \\
\hline 2006.11 .05 . & Darvas, Darvasi-halastavak & 2 \\
\hline 2006.11 .05 . & Geszt, Begécsi-víztároló & 1 juv. \\
\hline 2006.11 .05 . & Siófok, Balaton & 1 \\
\hline 2006.11 .07$. & Sarud, Tisza-tó (Sarudi-medence) & 1 juv. \\
\hline 2006.11 .09 . & Siófok-Balatonszéplak, Balaton & $1 \mathrm{ad}$. \\
\hline 2006.11 .11$. & Balatonlelle, Balaton & $1 \mathrm{ad}$. \\
\hline 2006.11 .12 . & Alsózsolca & 1 \\
\hline 2006.11 .12 . & Gárdony, Velencei-tó & 3 \\
\hline 2006.11 .13 . & Abádszalók, Tisza-tó (Abádszalóki-öböl) & 2 \\
\hline 2006.11 .13 . & Gárdony, Velencei-tó & 1 \\
\hline 2006.11 .14 & Gersekarát, Olimpiai-tó & 1 \\
\hline 2006.11 .15 . & Balmazújváros, Virágoskúti-halastó & 1 juv. \\
\hline 2006.11 .16$. & Gárdony, Velencei-tó & 2 \\
\hline 2006.11 .18 & Abádszalók, Tisza-tó (Abádszalóki-öböl) & 3 \\
\hline 2006.11 .19 . & Balatonőszöd, Balaton & 1 \\
\hline 2006.11 .19$. & Geszt, Begécsi-víztároló & 1 juv. \\
\hline 2006.11 .19 . & Soltvadkert, Vadkerti-tó & 1 \\
\hline 2006.11 .19 . & Zalavár, Kis-Balaton & 1 \\
\hline
\end{tabular}

Torday L.

Cser Sz., Faragó Á., Gál Sz.

Zalai T.

Zalai T.

Ampovics Zs., Domján A.

Lisztes A.

Molnár Sz., Vasas A.

Szűcs Cs., Fodor A., Lendvai Cs., Hegedüs D.

Zalai T.

Cser Sz., Faragó Á., Gál Sz.

Tar J., Zalai T.

Zwillinger D.

Fodor A., Lendvai Cs.

Zalai T.

Nehézy L.

Kis P.

Tar J., Ecsedi Z., Szilágyi A., Tihanyi G., Borza S.

Fodor A., Szücs Cs.

Kiss Á., Szepesváry Cs., Bodzás J. S.

Ampovics Zs., Domján A., Pigniczki Cs.,

Valkó O.

Simay G., Vince M.

Király E.

Ampovics Zs., Cser Sz., Domján A., Faragó Á., Futó R., Gál Sz., Lisztes A., Németh T., Pánya Cs., Pigniczki Cs., Valkó O. 


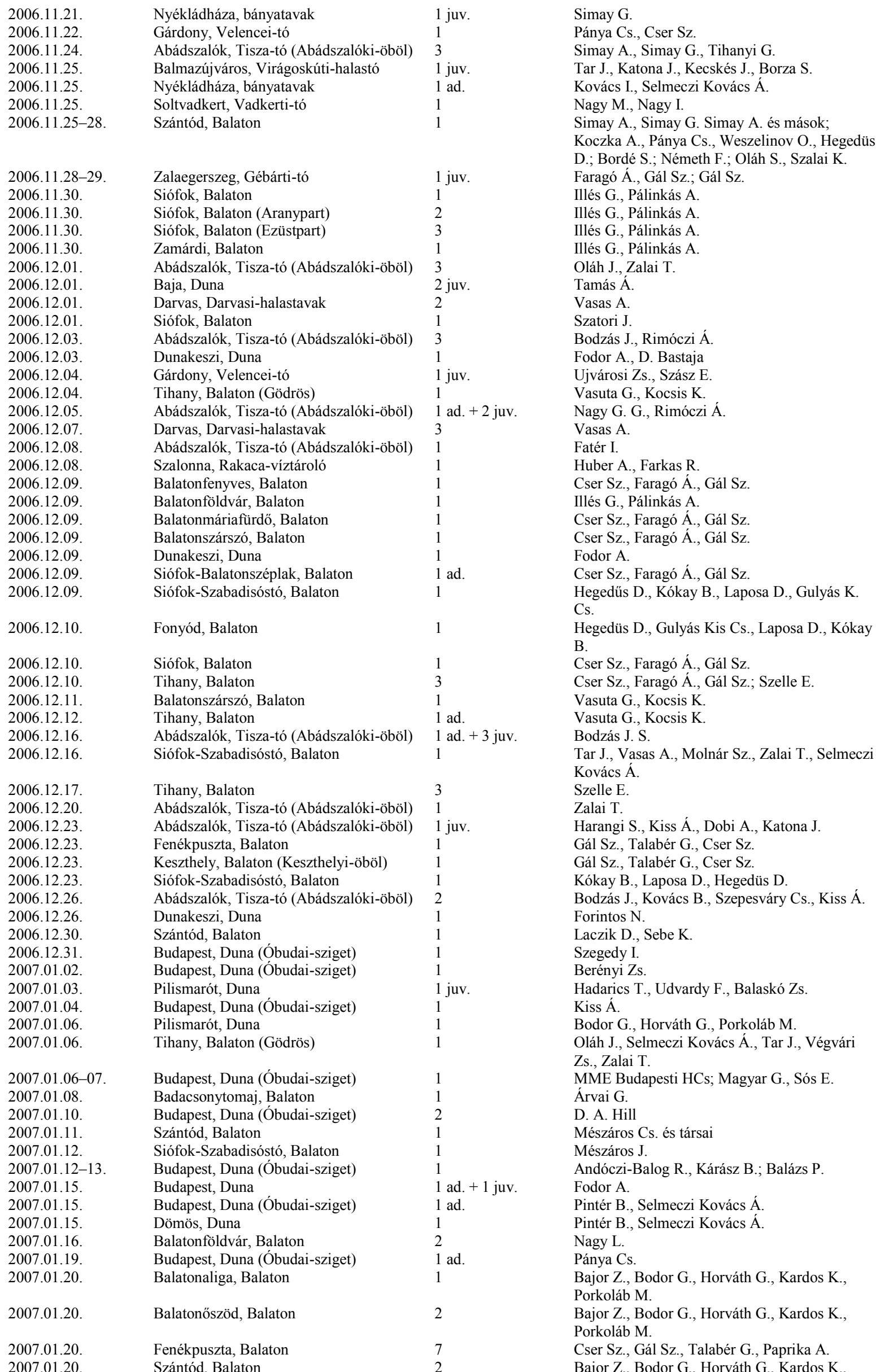




\begin{tabular}{|c|c|}
\hline 2007.01.20. & Tihany, Balaton (Gödrös) \\
\hline 2007.01.21. & Balatonföldvár, Balaton \\
\hline 2007.01.21. & Siófok, Balaton \\
\hline 2007.01.21. & Tihany, Balaton \\
\hline 2007.01.22. & Vác, Kisvác \\
\hline 2007.01.28. & Balatonalmádi, Balaton \\
\hline 2007.01.28. & Fertőrákos, Fertő (Rákosi-öböl) \\
\hline 2007.01.28. & Tihany, Balaton (Gödrös) \\
\hline 2007.01.31. & Balatonfüred, Balaton \\
\hline 2007.02.02. & Visegrád, Duna \\
\hline 2007.02.02. & Visegrád, Duna (Visegrádi-öböl) \\
\hline 2007.02.03. & Szántód, Balaton \\
\hline 2007.02.06. & Visegrád, Duna (Visegrádi-öböl) \\
\hline 2007.02.06. & Zalavár, Kis-Balaton \\
\hline 2007.02.10. & Dunakeszi, Duna \\
\hline 2007.02.11. & Kiskunlacháza, bányatavak \\
\hline 2007.02.15. & Hortobágy, Borsósi-halastó \\
\hline 2007.02.18. & Balatonfenyves, Balaton \\
\hline 2007.02.18. & Fonyód, Balaton \\
\hline 2007.02.18. & Szántód, Balaton \\
\hline 2007.02.18. & Zalavár, Kis-Balaton \\
\hline 2007.02.19. & Göd, Duna \\
\hline 2007.02.24. & Zalavár, Kis-Balaton \\
\hline 2007.02.25. & Siófok-Szabadisóstó, Balaton \\
\hline 2007.03.10. & Dunakeszi, Duna \\
\hline 2007.03.10. & Zalavár, Kis-Balaton \\
\hline 2007.03.15. & Budapest, Duna \\
\hline 2007.03.17. & Zalavár, Kis-Balaton \\
\hline 2007.03.20. & Dunakeszi, Duna \\
\hline 2007.04.04. & Kiskunlacháza, bányatavak \\
\hline 2007.04.08. & Kiskunlacháza, bányatavak \\
\hline 2007.05.04. & Dunaszentbenedek, Duna \\
\hline
\end{tabular}

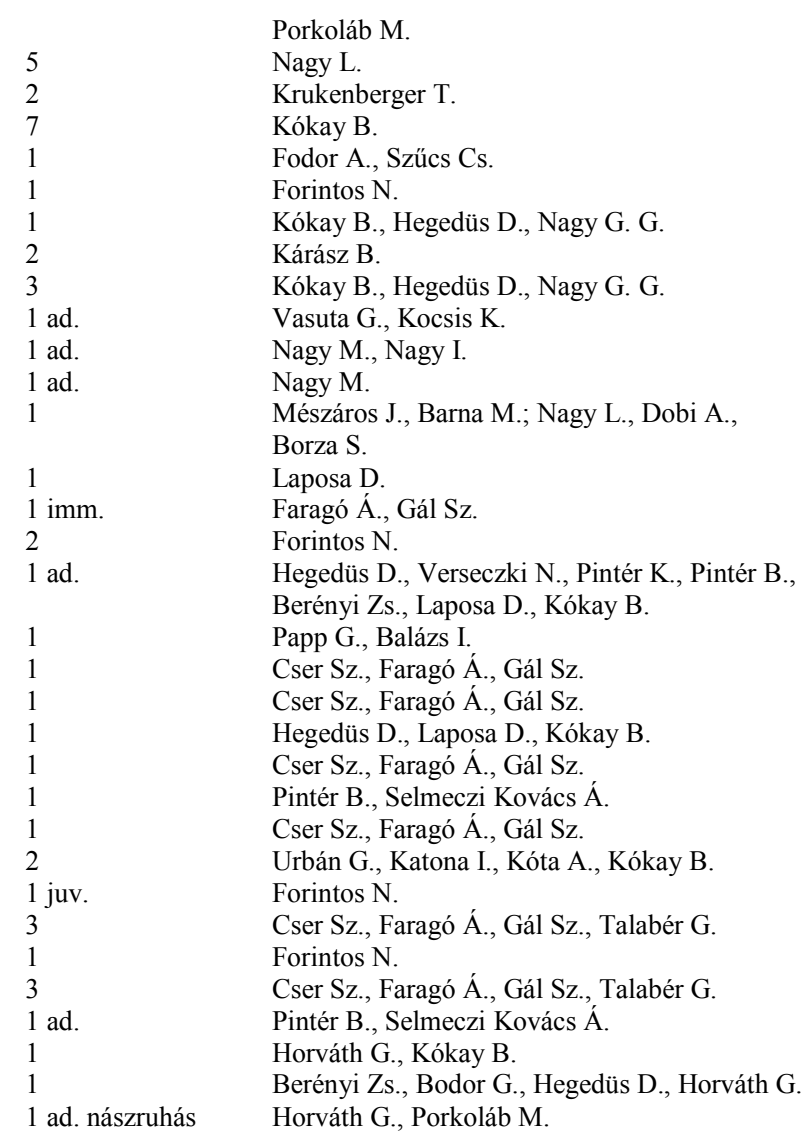

\subsection{Sarki búvár (Gavia arctica)}

Öszi vonulása során az elsők október közepén jelentek meg. Az elöfordulások zöme novemberre és decemberre esett. Legtöbb előfordulása a Balatonon volt, de szórványosan a Dunán, kisebb-nagyobb bányatavakon, illetve halastavakon is felbukkant. Legtöbbször egy vagy két, ritkábban 3-5 példányt észleltek, de Szántód és Tihany között többször is láttak 6-9 példányt egyszerre. 2007 január 20-án Balatonaligánál 10, március 12-én ugyanott 11 példányt számláltak. Érdekesség, hogy a szombathelyi Csónakázó-tavon egy nászruhás példány február közepétől egészen május végéig kitartott.

$\begin{array}{lll}2006.10 .13 . & \text { Hatvan, bányatavak } & 1 \text { juv. } \\ 2006.10 .14 . & \text { Dinnyés, Dinnyési-halastavak } & 1 \mathrm{ad} . \\ 2006.10 .14 . & \text { Fenékpuszta, Balaton } & 1 \\ 2006.10 .21 . & \text { Balatonföldvár, Balaton } & 1 \mathrm{ad} . \\ 2006.10 .21 . & \text { Szántód, Balaton } & 1 \\ 2006.10 .23 . & \text { Abádszalók, Tisza-tó (Abádszalóki-öböl) } & 1 \mathrm{ad} . \\ 2006.10 .23 . & \text { Harta, Duna } & 1 \\ 2006.10 .23 . & \text { Hatvan, bányatavak } & 1 \text { juv. } \\ 2006.10 .23 . & \text { Nyékládháza, bányatavak } & 1 \\ 2006.10 .23 . & \text { Pilismarót, Duna (Pilismaróti-öböl) } & 1 \\ 2006.10 .24 . & \text { Siófok, Balaton (Sió-torkolat) } & 1 \\ 2006.10 .25 . & \text { Szekszárd } & 1 \\ 2006.10 .26 . & \text { Fenékpuszta, Balaton } & 1 \\ 2006.10 .28 . & \text { Siófok, Balaton (Ezüstpart) } & 2 \\ 2006.10 .30 . & \text { Dunakeszi, Duna } & 1 \mathrm{ad} . \\ 2006.10 .31 . & \text { Keszthely, Balaton (Keszthelyi-öböl) } & 1 \\ 2006.11 .01 . & \text { Pilismarót, Duna (Pilismaróti-öböl) } & 1 \mathrm{ad} . \\ 2006.11 .02-03 . & \text { Zalaegerszeg, Gébárti-tó } & 1 \text { juv. } \\ 2006.11 .03 . & \text { Abádszalók, Tisza-tó (Abádszalóki-öböl) } & 1 \text { juv. } \\ 2006.11 .03 . & \text { Biharugra, Biharugrai-halastavak } & 1 \text { juv. } \\ 2006.11 .04 . & \text { Békéscsaba, téglagyári tavak } & 1 \mathrm{ad} . \\ 2006.11 .04 . & \text { Pilismarót, Duna (Pilismaróti-öböl) } & 1 \text { juv. } \\ 2006.11 .05 . & \text { Biharugra, Biharugrai-halastavak } & 3 \\ 2006.11 .05 . & \text { Zalaegerszeg, Gébárti-tó } & 2 \\ 2006.11 .08 . & \text { Zalaegerszeg, Gébárti-tó } & 2 \text { juv. } \\ 2006.11 .09 . & \text { Balatonmagyaród, Kis-Balaton (I. ütem) } & 1\end{array}$

Pintér B., Verseczki N.

Szeghalmi J.

Cser Sz., Faragó Á., Gál Sz., Talabér G.

Bajor Z., Bodor G., Horváth G.

Cser Sz., Faragó Á., Gál Sz.

Borbáth P.

Fábián P.-né; Király E., Bodrogi Zs.

Verseczki N., Pintér B., Szekeres P.

Kóta A. és társai

Selmeczi Kovács Á.

Lovászi P. és társai

Ampovics Zs.

Paprika A., Szeimann P.

Illés G., Pálinkás A.

Forintos N.

Cser Sz., Faragó Á., Gál Sz.

Bajor Z., Bodor G., Horváth G., Porkoláb M.

Gál Sz., Cser Sz.; Faragó Á., Gál Sz.

Zalai T.

Tőgye J.

Molnár Sz., Vasas A.

Magyar G.

Molnár Sz., Vasas A.

Cser Sz., Gál Sz.

Gál Sz.

Árvai G., P. A., Galambos M., Hatos V. 


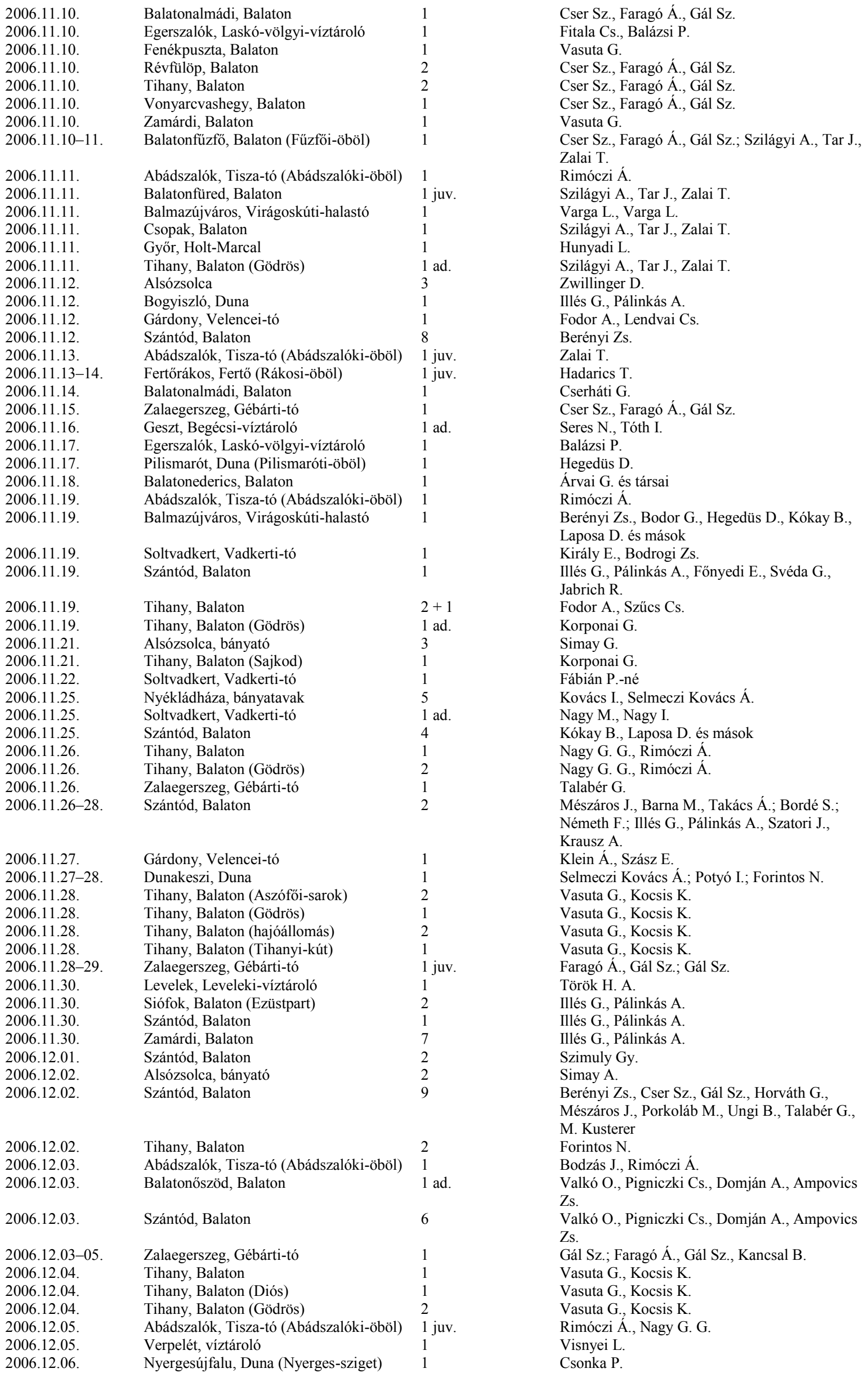




\begin{tabular}{|c|c|c|}
\hline 2006.12.07. & Tihany, Balaton (Gödrös) & 7 \\
\hline 2006.12.07-08. & Siófok, Balaton & 1 \\
\hline 2006.12.09. & Balatonaliga, Balaton & 3 \\
\hline 2006.12 .09 . & Balatonföldvár, Balaton & 2 \\
\hline 2006.12 .09 & Fonyód, Balaton & 1 \\
\hline 2006.12 .09 & Siófok, Balaton & 2 \\
\hline 2006.12.09. & Siófok-Szabadisóstó, Balaton & 4 \\
\hline 2006.12 .09 & Szántód, Balaton & 2 \\
\hline 2006.12 .09 & Zamárdi, Balaton & 4 \\
\hline 2006.12 .10 & Abádszalók, Tisza-tó (Abádszalóki-öböl) & $1 \mathrm{ad}$. \\
\hline 2006.12 .10 . & Balatonfüred, Balaton & 1 \\
\hline 2006.12 .10 . & Balatonfüzfö, Balaton (Fúzfői-öböl) & 2 \\
\hline 2006.12 .10 & Balatonvilágos, Balaton & 2 \\
\hline 2006.12 .10 & Csopak, Balaton & 1 \\
\hline 2006.12 .10 & Fenékpuszta, Balaton & 2 \\
\hline 2006.12 .10 & Tihany, Balaton & 6 \\
\hline 2006.12 .10 & Tihany, Balaton (Gödrös) & 6 \\
\hline 2006.12 .11 . & Balatonföldvár, Balaton & 1 \\
\hline 2006.12 .11 & Bősárkány, Nyirkai-Hany & 1 \\
\hline 2006.12 .11 & Fenékpuszta, Balaton & 1 \\
\hline 2006.12 .11 & Szántód, Balaton & 1 \\
\hline 2006.12 .11 & Zamárdi, Balaton & 1 \\
\hline 2006.12 .12 & Balatonfüzfö, Balaton (Fúzföi-öböl) & 1 \\
\hline 2006.12 .12 & Tihany, Balaton (Gödrös) & 1 \\
\hline 2006.12 .12 . & Tihany, Balaton (hajóállomás) & $2+1$ \\
\hline 2006.12 .12 . & Tihany, Balaton (rév) & 1 \\
\hline 2006.12 .12 & Tihany, Balaton (Tihanyi-sarok) & 1 \\
\hline 2006.12.14. & Balatonalmádi, Balaton & 1 \\
\hline 2006.12.15-16 & Szántód, Balaton & 1 \\
\hline 2006.12 .16 & Alsóörs, Balaton & 1 \\
\hline 2006.12 .16 & Balatonfüred, Balaton & 1 \\
\hline 2006.12 .16 & Balatonkenese, Balaton & 1 \\
\hline 2006.12 .16 & Csopak, Balaton & 1 \\
\hline 2006.12 .16 & Siófok, Balaton & 3 juv. \\
\hline 2006.12 .16 & Siófok-Szabadisóstó, Balaton & 1 \\
\hline 2006.12 .16 & Tihany, Balaton & 4 \\
\hline 2006.12 .17 & Siófok, Balaton & 4 \\
\hline 2006.12 .17 & Siófok-Szabadisóstó, Balaton & 2 \\
\hline 2006.12 .17 & Szántód, Balaton & 2 \\
\hline 2006.12 .17 & Tihany, Balaton & 1 \\
\hline 2006.12 .19 & Balatonalmádi, Balaton & 1 \\
\hline 2006.12 .20 & Siófok, Balaton & 2 \\
\hline 2006.12 .20 & Szántód, Balaton & 4 \\
\hline 2006.12 .20 & Szihalom, kavicsbányató & 1 \\
\hline 2006.12 .23 & Siófok, Balaton & 3 \\
\hline 2006.12 .23 & Szántód, Balaton & 1 \\
\hline 2006.12 .25 & Nyékládháza, bányatavak & 1 juv. \\
\hline 2006.12 .26 & Abádszalók, Tisza-tó (Abádszalóki-öböl) & 1 \\
\hline 2006.12 .26 & Balatonfüred, Balaton & 2 \\
\hline 2006.12 .26 & Siófok, Balaton & 3 \\
\hline 2006.12 .27 & Budapest, Duna & 1 \\
\hline 2006.12 .27 & Dunakeszi, Duna & 1 \\
\hline 2006.12 .27 & Tihany, Balaton & 1 \\
\hline 2006.12 .28 & Balatonfüred, Balaton & 1 \\
\hline 2006.12 .28 & Budapest, Duna (Szilas-patak torkolata) & 1 ad. \\
\hline 2006.12 .28 & Siófok, Balaton & 1 \\
\hline 2006.12 .29 & Tihany, Balaton (Somos) & 1 \\
\hline 2006.12 .31 & Balatonföldvár, Balaton & 1 \\
\hline 2006.12 .31 & Balatonfüzfö, Balaton (Fúzfói-öböl) & 2 \\
\hline 2006.12 .31 & Balatonvilágos, Balaton & $1 \mathrm{ad}$. \\
\hline 2006.12 .31 & Siófok, Balaton & 1 \\
\hline
\end{tabular}

Kaufman G.

Lovászi P., Mesterházy A.; Magyar G. és mások Hegedüs D., Kókay B., Laposa D., Gulyás K. Cs.

Illés G., Pálinkás A.

Cser Sz., Faragó Á., Gál Sz.

Oláh S.

Hegedüs D., Kókay B., Laposa D., Gulyás K.

Cs.; Fodor A., Haraszthy L.

Cser Sz., Faragó Á., Gál Sz.; Oláh S.

Cser Sz., Faragó Á., Gál Sz.

Bodor G., Horváth G., Kóta A., Porkoláb M., Ungi B.

Cser Sz., Faragó Á., Gál Sz.

Cser Sz., Faragó Á., Gál Sz.

Cser Sz., Faragó Á., Gál Sz.

Cser Sz., Faragó Á., Gál Sz.

Hegedüs D., Gulyás Kis Cs., Laposa D., Kókay

Cser Sz., Faragó Á., Gál Sz.

Szelle E.

Vasuta G., Kocsis K.

Pellinger A., Ferenczi M.

Vasuta G., Kocsis K.

Vasuta G., Kocsis K.; Kiss Á.

Vasuta G., Kocsis K.

Vasuta G., Kocsis K.

Vasuta G., Kocsis K.

Vasuta G., Kocsis K.

Vasuta G., Kocsis K.

Vasuta G., Kocsis K.

Cserháti G.

Tokody B., Kiss O.; Forintos N.; Bodor G. Horváth G., Pintér B., Selmeczi Kovács Á., Verseczki N.

Bodor G., Horváth G., Pintér B., Selmeczi

Kovács Á., Verseczki N.

Bodor G., Horváth G., Pintér B., Selmeczi

Kovács Á., Verseczki N.

Bodor G., Horváth G., Pintér B., Selmeczi

Kovács Á., Verseczki N.

Bodor G., Horváth G., Pintér B., Selmeczi

Kovács Á., Verseczki N.

Tar J., Vasas A., Molnár Sz., Zalai T.

Tar J., Vasas A., Molnár Sz., Zalai T.

Bodor G., Horváth G., Pintér B., Selmeczi

Kovács Á., Verseczki N.

Jakus L., Szatori J., Főnyedi E., IlIés G., Svéda G., Pálinkás A.

Vasas A., Molnár Sz., Tar J., Zalai T.

Vasas A., Molnár Sz., Tar J., Zalai T.

Szelle E.

Cserháti G.

Gyüre P., Török H. A., Weszelinov $\mathrm{O}$.

Gyüre P., Török H. A., Weszelinov O.

Visnyei L.

Pálinkás A.

KIss O., Tokody B.

Simay A., Simay A., Simay G.

Bodzás J., Kovács B., Szepesváry Cs., Kiss Á.

Korponai G.

Illés G., Pálinkás A.

Pintér B., Selmeczi Kovács Á.

Pintér B., Selmeczi Kovács Á.

Korponai G.

Oláh S., Szalai K.

Turny Z.

Oláh S., Szalai K.

Korponai G.

Jambrich R., Főnyedi E., Panyi E., Chiarelli G., Illés G., Pálinkás A

Szelle E., Széplaki I.

Magyar G., Schmidt A., Sós E.

Jambrich R., Főnyedi E., Panyi E., Chiarelli G., Illés G., Pálinkás A.

Horváth Cs. 


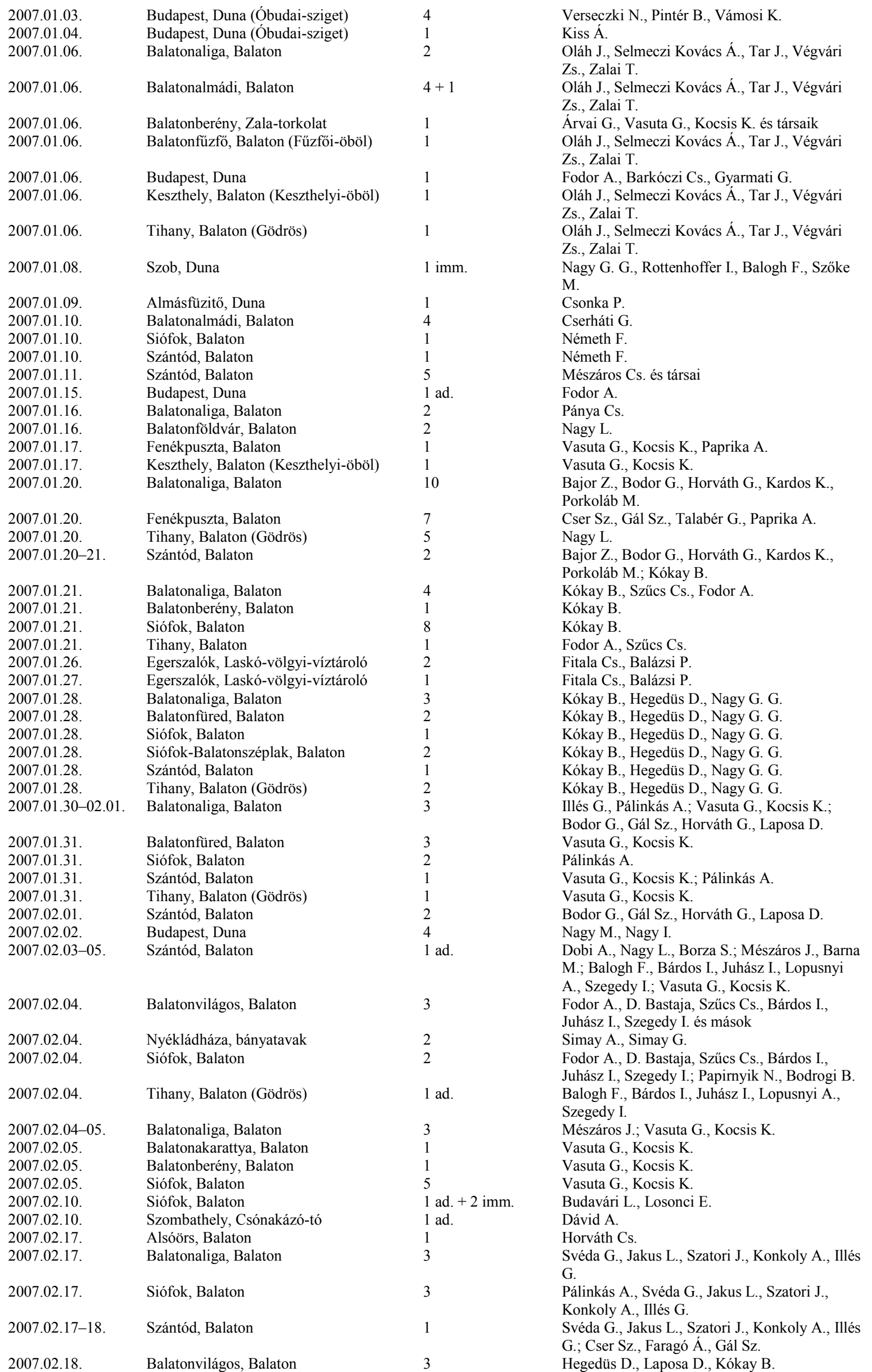




\begin{tabular}{|c|c|c|}
\hline 2007.02 .18 & Siófok, Balaton & 5 \\
\hline 2007.02 .25 & Balatonaliga, Balaton & 5 \\
\hline 2007.02 .25 & Balatonalmádi, Balaton & 1 \\
\hline 2007.02 .25 & Siófok, Balaton & 2 \\
\hline 2007.02 .25 & Siófok-Szabadisóstó, Balaton & 2 \\
\hline 2007.02 .25 & Szántód, Balaton & 1 \\
\hline 2007.03 .03 & Szántód, Balaton & 2 \\
\hline 2007.03 .07 & Szántód, Balaton & 2 \\
\hline 2007.03 .09 & Balatonfüzfö, Balaton (Füzfői-öböl) & 2 \\
\hline 2007.03 .10 & Balatonaliga, Balaton & 4 \\
\hline 2007.03 .11 & Balatonalmádi, Balaton & 5 \\
\hline 2007.03 .12 & Balatonaliga, Balaton & 11 \\
\hline 2007.03 .13 & Tihany, Balaton & 1 \\
\hline 2007.03 .15 & Balatonaliga, Balaton & 2 \\
\hline 2007.03 .15 & Szántód, Balaton & 2 \\
\hline 2007.03 .21 & Szombathely, Csónakázó-tó & $1 \mathrm{ad}$. \\
\hline 2007.03 .27 & Balatonalmádi, Balaton & 1 \\
\hline 2007.03 .28 & Tihany, Balaton (Sajkod) & 2 \\
\hline 2007.03 .30 & Szántód, Balaton & 2 \\
\hline 2007.04 .01 & Balatonaliga, Balaton & 2 \\
\hline 2007.04 .03 & Szántód, Balaton & 2 \\
\hline 2007.04 .03 & Tihany, Balaton & 1 \\
\hline 2007.04.03. & Tihany, Balaton (Gödrös) & 1 \\
\hline 2007.04.08-09. & Szántód, Balaton & 1 \\
\hline 2007.04.08-09. & Szombathely, Csónakázó-tó & $1 \mathrm{ad}$. \\
\hline 2007.04.09-10. & Tihany, Balaton (Gödrös) & 2 \\
\hline 2007.04.11. & Szombathely, Csónakázó-tó & $1 \mathrm{ad}$. \\
\hline 2007.04 .14 & Hatvan, bányatavak & $1 \mathrm{ad}$. \\
\hline 2007.04.21. & Tihany, Balaton (Sajkod) & $1 \mathrm{ad}$. \\
\hline 2007.04 .24 & Tihany, Balaton (Fehér-part) & 1 \\
\hline 2007.05 .02 & Szombathely, Csónakázó-tó & $1 \mathrm{ad}$. \\
\hline 2007.05 .06 & Szombathely, Csónakázó-tó & $1 \mathrm{ad}$. \\
\hline 2007.05 .08 & Szombathely, Csónakázó-tó & $1 \mathrm{ad}$. \\
\hline 2007.05.10. & Szombathely, Csónakázó-tó & $1 \mathrm{ad}$. \\
\hline 2007.05.12-14. & Szombathely, Csónakázó-tó & $1 \mathrm{ad}$. \\
\hline 2007.05.19-20. & Szombathely, Csónakázó-tó & $1 \mathrm{ad}$. \\
\hline 2007.05.25. & Szombathely, Csónakázó-tó & $1 \mathrm{ad}$. \\
\hline 2007.05 .27 & Szombathely, Csónakázó-tó & $1 \mathrm{ad}$. \\
\hline 2007.05 .31 & Szombathely, Csónakázó-tó & $1 \mathrm{ad}$. \\
\hline
\end{tabular}

Cser Sz., Faragó Á., Gál Sz.

Urbán G., Katona I., Kóta A., Kókay B.

Kókay B.

Urbán G., Katona I., Kóta A., Kókay B.

Urbán G., Katona I., Kóta A., Kókay B.

Urbán G., Katona I., Kóta A., Kókay B.

Ónodi M.

Szimuly Gy.

Cserháti G.

Pánya Cs.

Cserháti G.

Illés G., Pálinkás A.

Papirnyik N.

Szegedy I.

Szegedy I.

Gál J.

Cserháti G., Kovács A.

Bruckner A.

Steiner A., Szigeti B.

Mészáros J.

Árvai G., Bruckner A

Árvai G., Bruckner A.

Árvai G., Bruckner A.

Bárdos I.; Zalai T.

Farkas A., Farkas I.; Busa Á.

Zalai T.; Bruckner A.

Gergác T.

Verseczki N., Pintér K., Szenczi M., Szenczi G.

Tamás Á. és társai

Bruckner A.

Gál J.

Gergác T.

Kis $\mathrm{P}$.

Kis $\mathrm{P}$.

Hadarics T., Kozma Gy.; Gál J.; Vasuta G., Kocsis K.

Gál J.; Góczán J., Bagladi V.; Balaskó Zs.

Gál J.

Kóta A., Tóth T.,Tóth T., Tóth T.-né

Gál J.

\subsection{Jeges búvár (Gavia immer)}

A 2006/2007-es szezonban két előfordulása volt a fajnak hazánkban. 2006 novemberének végén egy fiatal madár jelent meg Szántódnál a Balatonon (VASUTA, 2006), és ez a példány egészen 2007 áprilisáig ott tartózkodott, ezalatt nagyon sok alkalommal megfigyelték. Egy másik - egy öreg, téli tollazatú - madár 2006 decemberének utolsó harmadában bukkant fel a Dunán (Pilismaróti-öböl), január első napjaiig többször észlelték ott. A faj Magyarországon rendkívül ritka, e két adatát a Nomenclator Bizottság a nyolcadik és a kilencedik hazai előfordulásként hitelesítette.

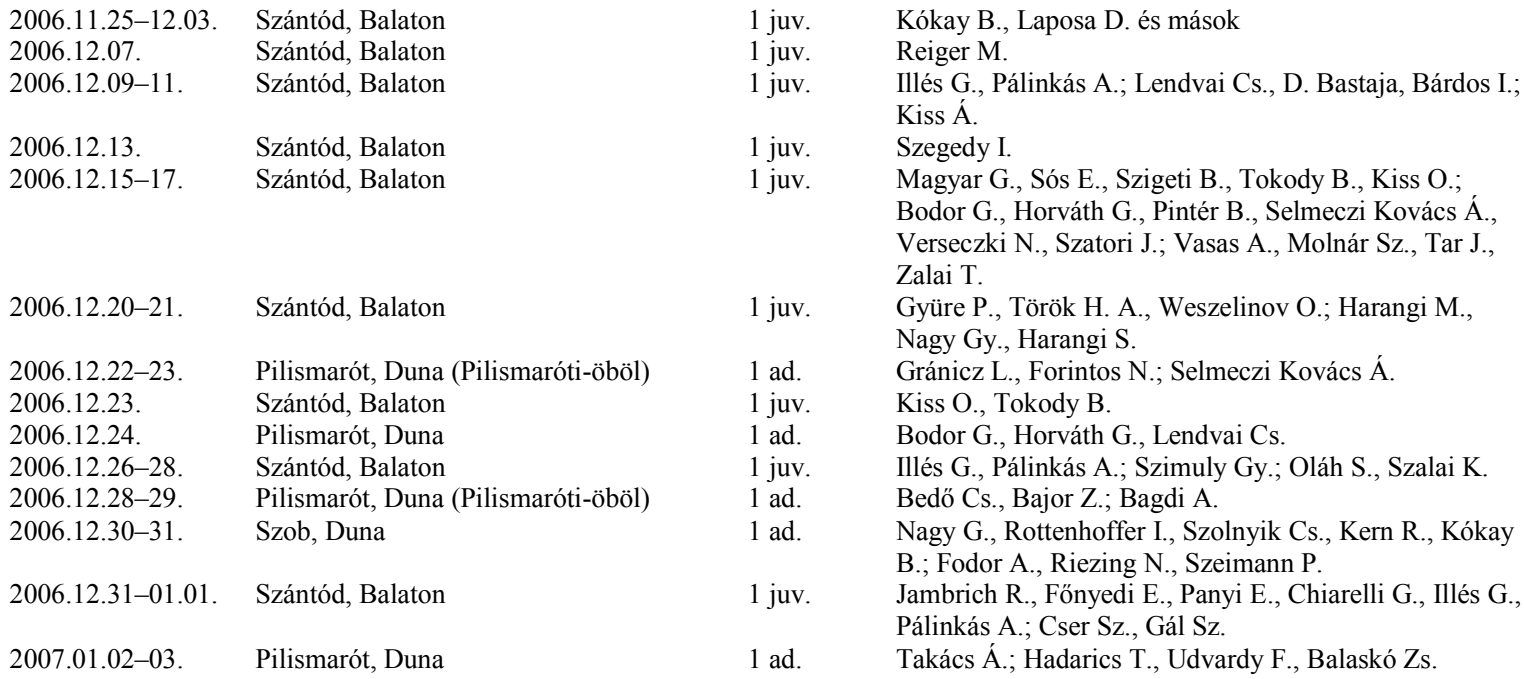




\begin{tabular}{|c|c|c|c|}
\hline 2007.01.28. & Tihany, Balaton & $1 \mathrm{imm}$. & Kókay B., Hegedüs D., Nagy G. G. \\
\hline 2007.01.31-02.01. & Szántód, Balaton & $1 \mathrm{imm}$. & $\begin{array}{l}\text { Kocsis K., Vasuta G.; Pálinkás A.; Bodor G., Gál Sz., } \\
\text { Horváth G., Laposa D. és mások }\end{array}$ \\
\hline $2007.02 .03-05$. & Szántód, Balaton & $1 \mathrm{imm}$. & $\begin{array}{l}\text { Mészáros J., Barna M.; Nagy L., Dobi A., Borza S.; } \\
\text { Balogh F., Bárdos I., Juhász I., Lopusnyi A., Szegedy I.; } \\
\text { Vasuta G., Kocsis K. }\end{array}$ \\
\hline 2007.02.06. & Tihany, Balaton & $1 \mathrm{imm}$. & Cserna Z. \\
\hline 2007.02.10-11. & Szántód, Balaton & $1 \mathrm{imm}$. & $\begin{array}{l}\text { Budavári L., Losonci E.; Illés G., Pálinkás A., Jakus L., } \\
\text { Svéda G. }\end{array}$ \\
\hline 2007.02.25. & Szántód, Balaton & $1 \mathrm{imm}$. & Krukenberger T. \\
\hline $2007.03 .02-03$. & Szántód, Balaton & $1 \mathrm{imm}$. & Cserna Z.; Ónodi M. \\
\hline 2007.03.07. & Szántód, Balaton & $1 \mathrm{imm}$. & Szimuly Gy. \\
\hline 2007.03 .15 . & Szántód, Balaton & $1 \mathrm{imm}$. & Magyar G., Pulay A.; Szegedy I. \\
\hline 2007.04.14. & Szántód, Balaton & $1 \mathrm{imm}$. & Laposa D., Hegedüs D., Bodor G., Horváth G., Kókay B. \\
\hline 2007.04.16-17. & Szántód, Balaton & $1 \mathrm{imm}$. & Illés G., Pálinkás A.; Juhász I. \\
\hline 2007.04.22. & Szántód, Balaton & $1 \mathrm{imm}$. & Illés G., Pálinkás A. \\
\hline
\end{tabular}

\subsection{Füles vöcsök (Podiceps auritus)}

Öszi vonuláson november közepétől január elejéig mutatkozott. Szinte mindig egyesével vagy kettesével látták, de december elején a Kis-Balatonon négy, december végén Tihanynál három példányt figyeltek meg egyszerre. Az előfordulások legnagyobb része a Balatonról származott. Tavaszi vonuláson április közepén került csak szem elé egy példány a mocsai Asszony-tavon.

\begin{tabular}{|c|c|c|c|}
\hline 2006.11.12. & Gárdony, Velencei-tó & 2 & Fodor A., Lendvai Cs. \\
\hline 2006.11 .19 . & Keszthely, Balaton (Keszthelyi-öböl) & 1 & Tomor Á. \\
\hline 2006.11.24. & Abádszalók, Tisza-tó (Abádszalóki-öböl) & 1 & Simay A., Simay G., Tihanyi G. \\
\hline $2006.11 .26-27$. & Nagyhegyes, Elepi-halastó & 1 ad. & Nagy M., Szilágyi A. \\
\hline 2006.11.30. & Pölöske, tőzegbányató & 1 & Cser Sz. \\
\hline 2006.12.01. & Abádszalók, Tisza-tó (Abádszalóki-öböl) & 2 & Oláh J. \\
\hline 2006.12 .05 & Abádszalók, Tisza-tó (Abádszalóki-öböl) & 1 & Nagy G. G., Rimóczi Á. \\
\hline 2006.12.07. & $\begin{array}{l}\text { Balatonmagyaród, Kis-Balaton (Kányavári- } \\
\text { sziget) }\end{array}$ & 4 & Lelkes A., Fitos E. \\
\hline 2006.12 .27 & Tihany, Balaton (Gödrös) & 3 & Korponai G. \\
\hline 2006.12 .29 & Tihany, Balaton (Gödrös) & 1 & Korponai G. \\
\hline 2006.12 .30 & Gárdony, Velencei-tó & 1 & $\begin{array}{l}\text { Szeghalmi J., Lopusnyi A., Balogh F., Bárdos I., Harka } \\
\text { L. }\end{array}$ \\
\hline 2006.12 .30 & Tihany, Balaton (Fehér-part) & 1 & Árvai G., Árvainé Tóth I., Galambos M., P. A. \\
\hline 2006.12 .30 & Tihany, Balaton (Gödrös) & 1 & Járosi A., Kovács G. K. \\
\hline 2007.01 .03 & Tihany, Balaton & 1 & Hadarics T., Udvardy F., Balaskó Zs. \\
\hline 2007.01.06. & Tihany, Balaton (Aszófói-sarok) & 2 & Korponai G. \\
\hline 2007.04 .11 & Mocsa, Asszony-tó & 1 & Pénzes L. \\
\hline
\end{tabular}

\subsection{Kis kárókatona (Phalacrocorax pygmeus)}

A faj egyre több helyen fészkel Magyarországon, ennek megfelelöen a költöhelyeken kívüli előfordulásai is egyre gyakoribbá váltak. Egyes területeken (föleg a költőhelyek közelében) annyira mindennapossá vált megfigyelése, hogy az adatokat a megfigyelök többnyire nem is töltik fel a www.birding.hu honlapra, így az itt közölt adatsor nem tükrözi teljes mértékben a faj előfordulásait. A költési időszak után a madarak egyes területeken viszonylag nagy számban gyülekeztek, pl. 2006. július 17-én a Kis-Balatonon 215 példányt, 2006. szeptember 8-án a tiszafüredi Kis-Jusztuson és a Kis-Balatonon egyaránt 
200-200 példányt, 2006. október 10-én a Hortobágyi-halastavon 230, 2006. november 17én ugyanott 140 példányt, 2007. január 13-án a szegedi Fehér-tavon 127 példányt, 2007. február 11-én a Kis-Balatonon 130 példányt számoltak. 2007-ben az összesítések alapján a magyarországi költőpárok száma 413-543 között volt (EÖRI, 2010), ami az előző évihez képest némi csökkenést jelent. A Hortobágyi-halastavon 60-80 pár, a Derzsi-halastavon 100-120 pár, a Kunkápolnási-mocsárban 30 pár fészkelt. 30-40 pár költött Tiszaalpár közelében, 20 pár pedig a Kis-Sárréten ( 8 pár a Biharugrai-halastavakon, 12 pár pedig az Ugrai-réten). A Kis-Balatonon 150-170 párra, a Nagy-berekben pedig 20-80 párra becsülték a költőpárok számát. 3 pár fészkelt a Rétszilasi-halastavakon, de valószínúleg Soponyán, a tömörkényi Csaj-tavon (1-2 pár) és a szegedi Fehér-tavon (2-3 pár) is költött.

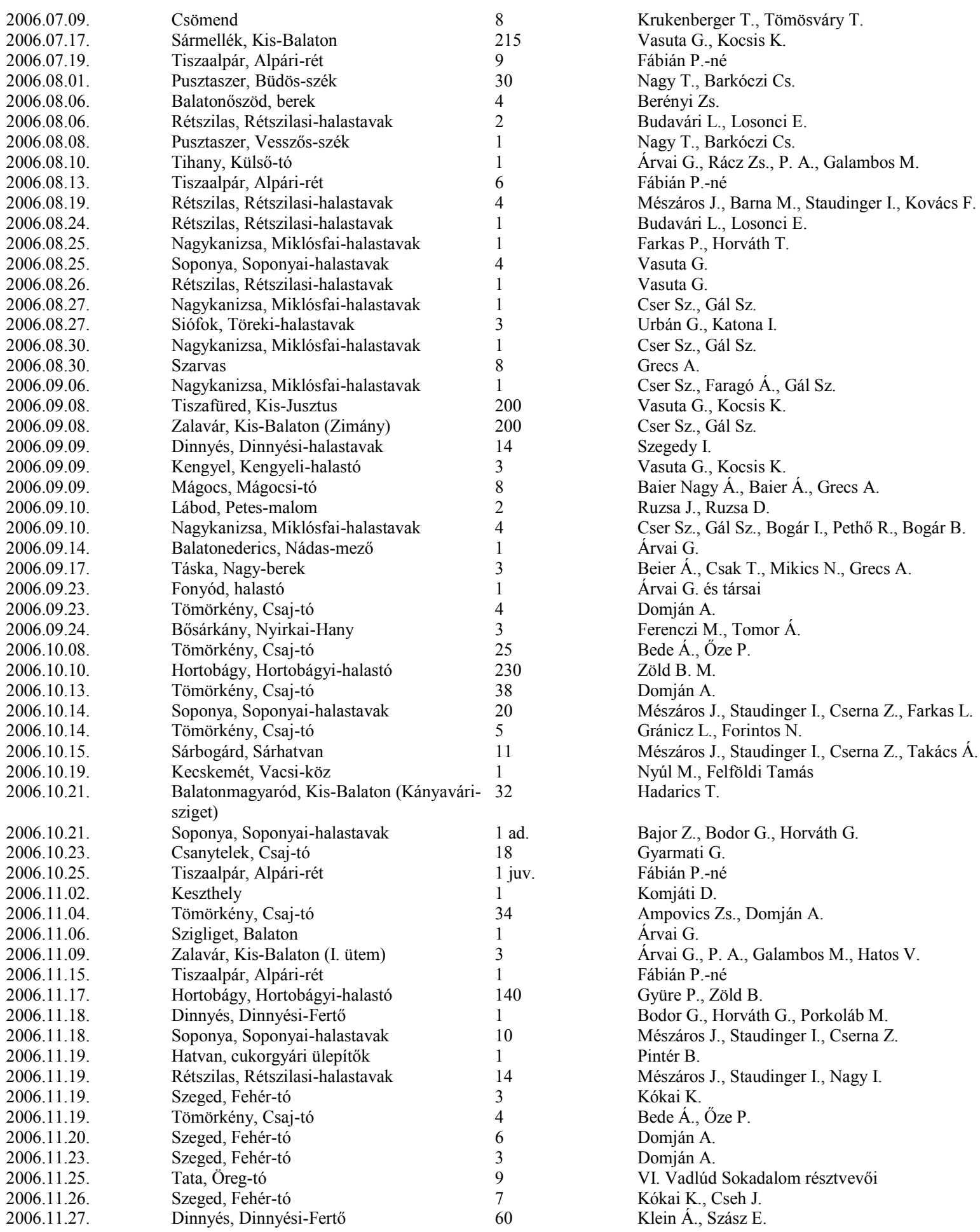




\begin{tabular}{|c|c|c|c|}
\hline 2006.11.29. & Balatongyörök, Balaton & 1 & Vasuta G., Kocsis K. \\
\hline 2006.11.29. & Sármellék, Kis-Balaton & 10 & Vasuta G., Kocsis K. \\
\hline 2006.12.04. & Szeged, Fehér-tó & 1 & Kókai K. \\
\hline 2006.12.07. & Szeged, Szegedi-Fertő & 1 & Hajas G. \\
\hline 2006.12.11. & Bősárkány, Nyirkai-Hany & 1 & Ferenczi M., Pellinger A. \\
\hline 2006.12.17. & Bősárkány, Nyirkai-Hany & 3 & Hunyadi L. \\
\hline 2006.12.17. & Rétszilas, Rétszilasi-halastavak & 1 & $\begin{array}{l}\text { Mészáros J., Staudinger I., Nagy I., Hajdú T., } \\
\text { Cserna Z. }\end{array}$ \\
\hline 2006.12.20. & Geszt, Begécsi-víztároló & $1 \mathrm{ad}$. & Seres N. \\
\hline 2006.12.22. & Tömörkény, Csaj-tó & 6 & Domján A. \\
\hline 2006.12.24. & Hortobágy, Csécsi-halastó & 23 & Weszelinov $\mathrm{O}$. \\
\hline 2006.12.24. & Hortobágy, Fényesi-halastó & 1 & Weszelinov $\mathrm{O}$. \\
\hline 2006.12.27. & Naszály, Ferencmajori-halastavak & 7 & Szimuly Gy. \\
\hline 2006.12.29. & Szeged, Fehér-tó & 5 & Lázár B., Bérdi G., Gyarmati G. \\
\hline 2006.12.30. & Szeged, Fehér-tó & 80 & Mészáros Cs., Engi L. \\
\hline 2006.12.31. & Fenékpuszta, Balaton & 40 & Cser Sz., Gál Sz., Talabér G., Kancsal B. \\
\hline 2006.12.31. & Hortobágy, Csécsi-halastó & 80 & Emri T., Zöld B. \\
\hline 2006.12.31. & Szeged, Fehér-tó & 28 & Kókai K., Nagy S., Magyar K. \\
\hline 2006.12.31. & Szob, Duna & $1 \mathrm{ad}$. & Fodor A., Riezing N., Szeimann P. \\
\hline 2006.12.31. & Tömörkény, Csaj-tó & 110 & Barkóczi Cs., Dörmer H. \\
\hline 2007.01.02. & Szeged, Fehér-tó & 23 & Domján A. \\
\hline 2007.01.03. & Szeged, Szegedi-Fertő & 1 & Kókai K. \\
\hline 2007.01.04. & Fertőhomok, Fertő & 1 & Mogyorósi S. \\
\hline 2007.01.05. & Szeged, Fehér-tó & 80 & Mészáros Cs., Engi L. \\
\hline 2007.01.05. & Szob, Duna & 1 & Prommer M. \\
\hline 2007.01.06. & Balatonberény, Zala-torkolat & 5 & Árvai G., Vasuta G., Kocsis K. és társaik \\
\hline 2007.01.06. & Fenékpuszta, Balaton & 4 & $\begin{array}{l}\text { Oláh J., Selmeczi Kovács Á., Tar J., Végvári Zs., } \\
\text { Zalai T. }\end{array}$ \\
\hline 2007.01.06. & Szeged, Fehér-tó & 1 & Kiss O., Borbáth E., Kammerer T., Tokody B. \\
\hline 2007.01.08. & Szeged, Fehér-tó & 11 & Kókai K. \\
\hline 2007.01.13. & Bősárkány, Nyirkai-Hany & 2 & Pellinger A., Ferenczi M., Tomor Á. \\
\hline 2007.01.13. & Szeged, Fehér-tó & 127 & Ampovics Zs., Domján A. \\
\hline 2007.01.14. & Apaj, Ürbői-halastavak & 1 & Fodor A., Lendvai Cs. \\
\hline 2007.01.14. & Szeged, Fehér-tó & 75 & Katona A., Ampovics Zs. \\
\hline 2007.01.14. & Tömörkény, Csaj-tó & 30 & Barkóczi Cs., Domján A. \\
\hline 2007.01.17. & Fenékpuszta, Balaton & 50 & Vasuta G., Kocsis K., Paprika A. \\
\hline 2007.02.02. & Szeged, Fehér-tó & 26 & Domján A. \\
\hline 2007.02 .03 . & Fehérvárcsurgó, Csurgói-víztároló & 1 & Árvai G. és társai \\
\hline 2007.02.04. & Abádszalók, Tisza-tó (Abádszalóki-öböl) & 6 & Csapó B., Csapó S. \\
\hline 2007.02 .04 . & Szeged, Fehér-tó & 15 & Ampovics Zs. \\
\hline 2007.02.04. & Tiszafüred, Tiszta-tó & 1 & Csapó B., Csapó S. \\
\hline 2007.02.04. & Tömörkény, Csaj-tó & 55 & Barkóczi Cs., Gyarmati G. \\
\hline 2007.02 .05 . & Badacsonytomaj, Balaton & 1 & Árvai G. \\
\hline 2007.02.05. & Balatonberény, Zala-torkolat & 5 & Vasuta G., Kocsis K. \\
\hline 2007.02.05. & Hahót, tőzegbányatavak & 2 & Faragó Á., Gál Sz. \\
\hline 2007.02.05. & Sármellék, Kis-Balaton & 100 & Vasuta G., Kocsis K. \\
\hline 2007.02.06. & Keszthely, Balaton (Keszthelyi-öböl) & 1 & Faragó Á., Gál Sz. \\
\hline 2007.02.11. & Szeged, Fehér-tó & 17 & Kókai K. \\
\hline 2007.02.11. & Zalavár, Kis-Balaton & 130 & Cser Sz. \\
\hline 2007.02.14. & Hahót, tőzegbányatavak & 2 & Cser Sz., Faragó Á. \\
\hline 2007.02.14. & Körmend, Rába-part & $1 \mathrm{ad}$. & Bedőcs Gy. \\
\hline 2007.02.17. & Bősárkány, Nyirkai-Hany & 1 & Tomor Á. \\
\hline 2007.02.17. & Kiskunlacháza, bányatavak & 1 & Bodor G., Horváth G., Kóta A., Tóth T. \\
\hline 2007.02.17. & Szeged, Fehér-tó & 94 & Domján A. \\
\hline 2007.02.18. & Szeged, Fehér-tó & 12 & Kiss O., Tokody B. \\
\hline 2007.02.18. & Tömörkény, Csaj-tó & 95 & Domján A. \\
\hline 2007.02.20. & Naszály, Ferencmajori-halastavak & 3 & Riezing N. \\
\hline 2007.02.21. & Szeged, Fehér-tó & 6 & Torday L. \\
\hline 2007.03.05. & Szeged, Fehér-tó & 1 & Kókai K., Cseh J. \\
\hline 2007.03.06. & Szeged, Szegedi-Fertő & 2 & Kókai K. \\
\hline 2007.03.09. & Körmend, Rába-part & $2 \mathrm{ad}$. & Bedőcs Gy. \\
\hline 2007.03.11. & Bősárkány, Nyirkai-Hany & 1 & László Cs., Tamás Á., Szász E., Kárász B. \\
\hline 2007.03.11. & Tápiószecső, halastavak & 9 & Benei B. \\
\hline 2007.03.13. & Balatonederics, Nádas-mező & 1 & Árvai G., Bruckner A. \\
\hline 2007.03.15. & Apaj, Ürbői-halastavak & 2 & Laposa D., Kókay B., Lendvai Cs. \\
\hline 2007.03.15. & Szeged, Fehér-tó & 17 & Kiss O., Aradi E., Tokody B. \\
\hline 2007.03.15. & Szentes, Termál-tó & $3 \mathrm{ad}$. & Fodor Cs. \\
\hline 2007.03.16. & Szeged, Fehér-tó & 4 & Tokody B. \\
\hline 2007.03.16. & Tihany, Külső-tó & 2 & Horváth Cs. \\
\hline 2007.03.16. & Tiszaalpár, Alpári-rét & 2 & Tölgyesi Cs. \\
\hline 2007.03.18. & Rétszilas, Rétszilasi-halastavak & 2 & Mészáros J., Staudinger I., Cserna Z., Farkas L. \\
\hline 2007.03.18. & Rétszilas, Rétszilasi-halastavak & 1 & Mészáros J., Staudinger I., Cserna Z., Farkas L. \\
\hline 2007.03.21. & Hortobágy, Hortobágyi-halastó & 4 & Balázsi P., Gilányi G. \\
\hline 2007.03.22. & Keszthely, Balaton (Keszthelyi-öböl) & 2 & Ampovics Zs. \\
\hline 2007.03.24. & Abádszalók, Tisza-tó (Abádszalóki-öböl) & 2 & Bodzás J. S. \\
\hline 2007.03.25. & Tápiószecső, halastavak & 1 & Ballmann M., Benei Zs., Benei B. \\
\hline
\end{tabular}




\begin{tabular}{|c|c|}
\hline 2007.03.28. & Zalavár, Balatonhídvég \\
\hline 2007.04 .02 & Hortobágy, Hortobágyi-halastó \\
\hline 2007.04 .06 & Balatonmagyaród, Kis-Balaton (II. ütem) \\
\hline 2007.04 .06 & Balatonmagyaród, Zala \\
\hline 2007.04 .06 . & Naszály, Ferencmajori-halastavak \\
\hline 2007.04 .07 & Hortobágy, Hortobágyi-halastó \\
\hline 2007.04 .08 & Hortobágy, Hortobágyi-halastó \\
\hline 2007.04 .08 . & Rétszilas, Rétszilasi-halastavak \\
\hline 2007.04 .08 & Tápiószecső, halastavak \\
\hline 2007.04 .10 & Tápiószecső, halastavak \\
\hline 2007.04 .14 & Tömörkény, Csaj-tó \\
\hline 2007.04 .15 & Rétszilas, Rétszilasi-halastavak \\
\hline 2007.04.15-16. & Apaj, Alsó-Szúnyog \\
\hline 2007.04.29. & Zalavár, Kis-Balaton (II. ütem) \\
\hline 2007.05 .13 & Biatorbágy, halastavak \\
\hline 2007.05 .13 & Naszály, Ferencmajori-halastavak \\
\hline 2007.05 .21 & Tiszaalpár, Alpári-rét \\
\hline 2007.05 .28 & Szeged, Fehér-tó \\
\hline 2007.06 .05 & Tiszaalpár, Alpári-rét \\
\hline 2007.06 .09 & Tiszaalpár, Alpári-rét \\
\hline 2007.06 .11 & Harta, Duna \\
\hline 2007.06 .15 & Nagykanizsa, Miklósfai-halastavak \\
\hline 2007.06 .16 & Marcali, víztároló \\
\hline 2007.06 .17 & Balatonboglár, Balaton \\
\hline 2007.06 .17 & Tiszaalpár, ártér \\
\hline 2007.06 .20 & Abádszalók, Tisza-tó (Abádszalóki-öböl) \\
\hline 2007.06 .22 & Balatonberény, Balaton \\
\hline 2007.06 .24 & Balatonlelle, Irmapusztai-halastavak \\
\hline 2007.06 .25 . & Hahót, tőzegbányatavak \\
\hline 2007.06 .25 . & Tiszaalpár, Alpári-rét \\
\hline 2007.06 .27 & Nagykanizsa, Miklósfai-halastavak \\
\hline
\end{tabular}

12
4
6
3
1
1
3
7
7
7
7
4
2

2
1
1
5
2
8
2
$1 \mathrm{ad}$.
1
21
1
80
5
1
1
1
26
1

Bruckner A.

Balázsi P., Gilányi G.

Árvai G., Bruckner A. és társaik

Arvai G., Bruckner A. és társaik

Riezing N.

Nagy M.

Kiss Á., Kardos É., Kiss J.

Vasuta G., Kocsis K.

Pintér B., Verseczki N.

Benei B.

Domján A.

Mészáros J., Staudinger I., Farkas L.

Fodor A., Lendvai Cs., D. Bastaja, Szücs Cs.;

Szél L.

Kiss Á., Kardos É., Kiss J.

Ungi B.

Riezing N.

Fábián P.-né

Mészáros Cs., Engi L.

Fábián P.-né

Kiss Á., Kardos É.

Berdó J., Kovács S.

Faragó Á., Gál Sz.

Nagy E., Nagy Á.

Kovács Gy.

Fodor A.

Bodzás J. S.

Faragó Á., Gál Sz.

Illés G., Jakus J., Jakus L., Pálinkás A., Svéda

G., Kovács Gy.

Faragó Á., Gál Sz., Talabér G.

Fábián P.-né

Faragó Á., Gál Sz.

\subsection{Rózsás gödény (Pelecanus onocrotalus)}

Magyarországon ritkán megjelenő madárfaj. A 2007. február 7-én Péteri mellett megfigyelt öreg madár adatát a Nomenclator Bizottság $\mathrm{D}_{\mathrm{A}}$ kategóriásnak fogadta el, azaz a madár vad eredete tekintetében merültek fel bizonyos kételyek (főleg az elöfordulás szokatlan időpontja miatt). A május végi és júniusi adatok mind ugyanarra az átszíneződő (vad eredetü) példányra vonatkoznak, amely először a szabadszállási Zab-széken bukkant fel május végén, majd Tiszabábolnán, később pedig Mezőnagymihálynál látták (a madár egyébként egészen 2007 decemberéig Magyarországon tartózkodott, szeptember és december között a Hortobágy térségében látták többször, mígnem december közepén a Polgári-halastavakon találták meg elpusztulva).

$\begin{array}{lll}\text { 2007.02.07. } & \text { Péteri, horgásztó } & 1 \mathrm{ad} .\left(\mathrm{D}_{\mathrm{A}}\right) \\ \text { 2007.05.27. } & \text { Szabadszállás, Zab-szék } & 1 \mathrm{imm} . \\ \text { 2007.06.01. } & \text { Tiszabábolna, Nagy-Szék-lápa } & 1 \mathrm{imm} . \\ \text { 2007.06.18-20. } & \text { Mezőnagymihály, Gyékényes-mocsár } & 1 \mathrm{imm} . \\ \text { 2007.06.23. } & \text { Mezőnagymihály, Gyékényes-mocsár } & 1 \mathrm{imm} . \\ 2007.06 .26-27 . & \text { Mezőnagymihály, Gyékényes-mocsár } & 1 \mathrm{imm} .\end{array}$

Csiszár T

Csaplár K.

Fatér I., H. Tiedemann, Seres N., Kleszó A. Seres N., Ferencz A., Kleszó A.; Fehér F., Seres N., Juhász I., Ferencz A.; Kókay B. és mások Seres N., Laposa D., Lendvai Cs., Steiner A., Nehézy L., Nehézy D.

Seres N., Pintér B., Mazula A., Balázsi P.; Seres N., Varga L.

\subsection{Sujtásos fütyülőlúd (Dendrocygna bicolor)}

2006 augusztusának közepétől október végéig tartózkodott a Hortobágyi-halastavon ez a Magyarországon korábban még soha nem látott madárfaj. Az adatot a Nomenclator Bizottság $\mathrm{D}_{\mathrm{E}}$ kategóriásnak fogadta el, azaz a bizottság a madár eredetét bizonytalannak itélte, úgy vélekedett, hogy a fogságból való szökés ugyan valószínűbb, de azért a vad eredet sem zárható ki teljesen.

\begin{tabular}{|c|c|c|c|}
\hline 2006.08 .17 . & Hortobágy, Hortobágyi-halastó & 1 ad. $\left(D_{E}\right)$ & $\begin{array}{l}\text { Ecsedi Z., Oláh J., Szilágyi A., Tar J., Tihanyi } \\
\text { G., Vasas A. és mások }\end{array}$ \\
\hline 2006.08 .25 . & Hortobágy, Hortobágyi-halastó & 1 ad. $\left(D_{E}\right)$ & Gyüre P. \\
\hline
\end{tabular}


2006.09.01-02. Hortobágy, Hortobágyi-halastó (Kondás) 1 ad. ( $\left.\mathrm{D}_{\mathrm{E}}\right)$ 2006.10.14-15. Hortobágy, Hortobágyi-halastó (Kondás) 1 ad. ( $\left.\mathrm{D}_{\mathrm{E}}\right)$

2006.10.27. Hortobágy, Hortobágyi-halastó (Kondás) 1 ad. ( $\left.\mathrm{D}_{\mathrm{E}}\right)$
Nagy G. G.; Juhász I., Fehér F. és mások Oláh J.; Fodor A., Kovács G., Szücs Cs. és mások

Nehézy L., Nehézy L.-né

\subsection{Kis hattyú (Cygnus columbianus)}

A 2006/2007-es szezonban - bár a faj előfordulásai évről évre gyakoribbá válnak mindössze egy adat érkezett a fajról. Az őszi vonulás során (október közepe) három példány (két öreg és egy fiatal) került szem elé a Hortobágyi-halastavon. Az adatot a Nomenclator Bizottság Hitelesítette.

2006.10.16. Hortobágy, Hortobágyi-halastó (Kondás) 2 ad. + 1 juv. Tar J., Kovács G., Szilágyi A.

\section{9. Énekes hattyú (Cygnus cygnus)}

Az Ipoly-völgyben költő madarakon - melyeket rendszeresen megfigyeltek a fészkelöhely környékén - kívül szinte az egész szezonban jelen volt egy öreg példány a geszti Begécsivíztárolón. 2006 októberének végén a tatai Öreg-tavon négy példányt láttak. November elején három öreg madár tünt fel a Hortobágyon, majd nem kizárt, hogy ezek a madarak húzódtak le a Csaj-tó és Pusztaszer környékére, ahol november közepétől február közepoéig rendszeresen látták őket. Ezeken kívül 2006 novemberében a tiszavasvári Fehér-sziken, illetve 2007 januárjának második felében a nyíregyházi Szelkó-tavon is láttak két-két példányt. 2007-ban ismét költött egy pár az Ipoly árterén (Drégelypalánk, Csadó-tanya), ebben az évben négy fiókát neveltek (a fajnak ez a harmadik fészkelési adata Magyarországon) (SELMECZI KovÁCS, 2014).

\begin{tabular}{|c|c|c|}
\hline 2006.07.29. & Dejtár, Ipoly-völgy & 2 ad. \\
\hline 2006.07 .31 & Geszt, Begécsi-víztároló & 1 ad. \\
\hline 2006.08 .07 & Geszt, Begécsi-víztároló & 1 \\
\hline 2006.08 .09 & Madaras, Príszpa-horgásztó & 1 ad. hím \\
\hline 2006.08 .12 . & Geszt, Begécsi-víztároló & $1 \mathrm{ad}$ \\
\hline 2006.08 .19 . & Geszt, Begécsi-víztároló & $1 \mathrm{ad}$. \\
\hline 2006.08.21. & Geszt, Begécsi-víztároló & 1 \\
\hline $2006.08 .25-26$. & Geszt, Begécsi-víztároló & $1 \mathrm{ad}$. \\
\hline 2006.08 .28 & Geszt, Begécsi-víztároló & 1 ad. \\
\hline 2006.08 .30 & Geszt, Begécsi-víztároló & 1 ad. \\
\hline 2006.09 .04 & Geszt, Begécsi-víztároló & $1 \mathrm{ad}$. \\
\hline 2006.09 .06 & Dejtár, Ipoly-völgy & 4 \\
\hline 2006.09 .08 & Geszt, Begécsi-víztároló & 1 ad. \\
\hline 2006.09 .17$. & Geszt, Begécsi-víztároló & 1 \\
\hline 2006.09 .30 & Geszt, Begécsi-víztároló & $1 \mathrm{ad}$. \\
\hline 2006.10 .29 & Geszt, Begécsi-víztároló & 1 ad. \\
\hline 2006.10 .31 & Tata, Öreg-tó & 4 \\
\hline 2006.11 .04 & Hortobágy, Ohat & 3 ad. \\
\hline 2006.11 .06 & Hortobágy, Ohat & 3 ad. \\
\hline 2006.11 .12 & Tömörkény, Csaj-tó & 3 ad. \\
\hline 2006.11 .16 & Biharugra, Biharugrai-halastavak & 2 ad. \\
\hline $2006.11 .16-17$. & Tömörkény, Csaj-tó & 3 ad. \\
\hline 2006.11.18. & Tiszavasvári, Fehér-szik & 2 \\
\hline 2006.11 .19 & Tömörkény, Csaj-tó & 3 ad. \\
\hline 2006.11.21-22. & Pusztaszer, Büdös-szék & 3 ad. \\
\hline 2006.11.24. & Pusztaszer, Büdös-szék & 3 ad. \\
\hline $2006.11 .24-25$. & Geszt, Begécsi-víztároló & 1 \\
\hline 2006.11 .26 & Tiszavasvári, Fehér-szik & 2 \\
\hline 2006.11.27. & Pusztaszer, Büdös-szék & 3 ad. \\
\hline 2006.12 .01 & Pusztaszer, Büdös-szék & 3 ad. \\
\hline 2006.12 .04 & Biharugra, Biharugrai-halastavak & 1 ad. \\
\hline 2006.12 .06 & Pusztaszer, Büdös-szék & 3 ad. \\
\hline 2006.12 .07 & Pusztaszer, Büdös-széki-puszta & 3 \\
\hline 2006.12 .08 & Biharugra, Biharugrai-halastavak & 1 ad. \\
\hline 2006.12 .20 & Biharugra, Biharugrai-halastavak & $1 \mathrm{ad}$. \\
\hline 2006.12 .22 & Pusztaszer, Büdös-szék & 3 ad. \\
\hline 2006.12 .22 & Tömörkény, Csaj-tó & $3 \mathrm{ad}$. \\
\hline 2006.12 .26 & Tömörkény, Csaj-tó & 3 ad. \\
\hline 2006.12 .27 & Biharugra, Biharugrai-halastavak & 1 \\
\hline 2006.12 .28 & Tömörkény, Csaj-tó & 3 ad. \\
\hline 2006.12 .31 & Tömörkény, Csaj-tó & 3 ad. \\
\hline
\end{tabular}

Selmeczi Kovács Á.

Seres N., Simay G.

Nagy G., Pabar Z., Seres N., Simay G.

Mazács D.

Simay A., Simay G.

Oláh J., Tar J., Zalai T. és társaik

Gubicskó L., Seres N., Nagy B.

Seres N., Tóth I.; Seres N.

Seres N.

Seres N., Durkó L., Márkus Gy.

Seres N.

Selmeczi Kovács Á

Seres N.

Molnár Sz., Seres N., Simay G., Vasas A.

Seres N.

Seres N., Kazi R., Schmidt A., Fézler G.,

Varga P., Potyó I., Megyery Á.

Csonka P.

Seprényi A., Nagy A.

Seprényi A.

Barkóczi Cs., Lázár B., Gyarmati G.

Seres N., Tóth I., Tőgye J.

Nagy T.; Nagy T., Hajas G.

Simon Gy.

Bede Á., Öze P.

Nagy T.

Nagy T. és társai

Gubicskó L., Seres N.; Durkó L., Hegyesi A.

Simon Gy.

Nagy T.

Nagy $T$.

Seres N.

Nagy $\mathrm{T}$.

Kiss O., Tokody B.

Seres N.

Seres N.

Nagy $\mathrm{T}$.

Domján A.

Barkóczi Cs., Szakács I.

Seres N., Kiss Á., Pabar Z., Monoki Á.

Nagy M., Nagy I.

Barkóczi Cs., Dörmer H. 


\begin{tabular}{|c|c|c|c|}
\hline 2007.01 .09 . & Pusztaszer, Büdös-szék & $3 \mathrm{ad}$. & Nagy T. \\
\hline 2007.01 .14 . & Tömörkény, Csaj-tó & $3 \mathrm{ad}$. & Barkóczi Cs., Domján A. \\
\hline 2007.01 .21 . & Nyíregyháza, Szelkó-tó & 2 & Kiss D., Török H. A. \\
\hline 2007.02 .01 . & Pusztaszer, Büdös-széki-puszta & 3 & Tokody B. \\
\hline 2007.02 .04 . & Tömörkény, Csaj-tó & $3 \mathrm{ad}$. & Barkóczi Cs., Gyarmati G. \\
\hline 2007.02 .10 . & Pusztaszer, Büdös-szék & 3 & Fodor A. \\
\hline 2007.02 .20 . & Tömörkény, Csaj-tó & $3 \mathrm{ad}$. & Nagy $\mathrm{T}$. \\
\hline 2007.03 .17 . & Drégelypalánk, Csadó-tanya & $2 \mathrm{ad}$. & Selmeczi Kovács Á. és társai \\
\hline 2007.03 .24 . & Drégelypalánk, Csadó-tanya & 4 & Papp F. \\
\hline 2007.03 .27 . & Drégelypalánk, Csadó-tanya & 1 pár & Selmeczi Kovács Á. \\
\hline 2007.03 .30 . & Drégelypalánk, Ipoly-völgy & 1 & Harmos K., Csernák Sz. \\
\hline 2007.04 .13 . & Drégelypalánk, Ipoly-völgy & $1 \mathrm{ad}$. & Selmeczi Kovács Á. \\
\hline 2007.04 .15 . & Biharugra, Biharugrai-halastavak & $1 \mathrm{ad}$. & Molnár Sz., Vasas A. \\
\hline 2007.05 .08 . & Drégelypalánk, Ipoly-völgy & $2 \mathrm{ad}$ & Selmeczi Kovács Á. \\
\hline 2007.05 .15 . & Drégelypalánk, Ipoly-völgy & 2 ad. +3 pull. & $\begin{array}{l}\text { Ecsedi Z., Oláh J., Selmeczi Kovács Á., Zalai } \\
\text { T. }\end{array}$ \\
\hline 2007.06 .03 . & Drégelypalánk, Ipoly-völgy & 2 ad. +4 juv. & Selmeczi Kovács Á. \\
\hline 2007.06 .24 & Geszt, Begécsi-víztároló & 1 & Vasas A., Mazula A. \\
\hline
\end{tabular}

\subsection{Rövidesőrü lúd (Anser brachyrhynchus)}

A faj 2006. évi megfigyelései valószínüleg ugyanarra a példányra vonatkoznak: a madár elöbb a Kis-Balatonon, majd a Fertő környékén bukkant fel (HADARICS, 2008). Az adatot a Nomenclator Bizottság hitelesítette, így ez a 13. hazai előfordulása ennek a Magyarországon rendkívül ritka lúdfajnak.

$\begin{array}{llll}\text { 2006.10.23. } & \text { Zalavár, Kis-Balaton (Bárándi-víz) } & 1 \mathrm{ad} . & \text { Cser Sz., Faragó Á., Gál Sz. } \\ \text { 2006.11.01-05. } & \text { Fertóúlak, Borsodi-dülő } & 1 \mathrm{ad} . & \text { Tamás Á, László Cs., Pellinger A., Mogyorósi S., } \\ & & & \text { Hadarics T., Neuwirth N., Fodor A. és mások } \\ \text { 2006.11.12. } & \text { Fertőújlak, Fésüs-sarok } & 1 \mathrm{ad} . & \text { Tar J., Zalai T., Ferenczi M., Pellinger A. }\end{array}$

\subsection{Kis lilik (Anser erythropus)}

A skandináv populáció Hortobágyon átvonuló egyedei már szeptember végén megérkeztek, ekkor 19 példányt látak a Hortobágyi-halastavon (október végén pedig ugyanott 22-t). Október végétől március közepéig lehetett magányos példányokat vagy kisebb, néhány példányból álló csapatokat megfigyelni a nagyobb vadlúdtömegekben. Elsősorban a Dunától keletre mutatkozott, a Dunántúlon, csak a Fertő környékén, a Tata térségében, illetve egy alkalommal Dinnyésen voltak előfordulásai. A skandináv populáció egyedei a tavaszi vonulás során március utolsó hetében bukkantak fel a Hortobágyon (Hortobágyi-halastó) és egészen április közepéig itt tartózkodtak, az ezen időszakban számolt legtöbb madár 43 példány volt (2007. április 2-án a Hortobágyi-halastavon).

$\begin{array}{llll}2006.09 .30 . & \text { Hortobágy, Hortobágyi-halastó } & 19 & \text { Gyüre P. } \\ 2006.10 .15 . & \text { Hortobágy, Hortobágyi-halastó } & 2 & \text { Kovács G., Fodor A., Szücs Cs. } \\ 2006.10 .19 . & \text { Hortobágy, Hortobágyi-halastó (Kondás) } & 9 & \text { Ecsedi Z., Oláh J. } \\ 2006.10 .21 . & \text { Hortobágy, Hortobágyi-halastó } & 1 & \begin{array}{l}\text { Fodor A., Kovács G., Riezing N., Szücs Cs., } \\ \text { Weszelinov O. }\end{array} \\ 2006.10 .21 . & \text { Tiszafüred, Jusztus } & 1 \text { ad. } & \text { Riezing N. } \\ 2006.10 .26 . & \text { Fertóújlak, Borsodi-dülő } & 1 \text { ad. } & \text { László Cs., Tamás Á. } \\ 2006.10 .27 . & \text { Hortobágy, Derzsi-halastó } & 22 & \text { Végvári Zs. } \\ 2006.10 .28 . & \text { Hortobágy, Csécsi-halastó } & 1 \text { subad. } & \text { Járosi A., Kovács G. K. } \\ 2006.10 .31 . & \text { Szabadszállás, Büdös-szék } & 1 \text { ad. } & \text { Pigniczki Cs. } \\ 2006.11 .01 . & \text { Egyek } & 5 & \text { Seprényi A. } \\ 2006.11 .02 . & \text { Fertőújlak, Borsodi-dülő } & 2 & \text { Ferenczi M., Pellinger A. } \\ 2006.11 .04 . & \text { Apaj, halastavak } & 1 \text { ad. } & \text { Fehérvári P., Vandlik O., Spolár Z. } \\ 2006.11 .04-05 . & \text { Fertőújlak, Borsodi-dülő } & 1 & \text { Horváth G., Tamás Á., Kárász B., László Cs., } \\ & & & \text { Ferenczi M., Tomor Á., Steiner A., Simay G., } \\ & & 2 \text { subad. + 1 juv. } & \text { Weszelinov O., Kókay B.; J. Laber } \\ 2006.11 .06-07 . & \text { Fertőújlak, Borsodi-dülő } & & \text { Juhász I. }\end{array}$




\begin{tabular}{|c|c|c|c|}
\hline 2006.11 .07$. & Fülöpszállás, Kelemen-szék & 1 ad. & Pigniczki Cs. \\
\hline 2006.11 .08 & Dinnyés, Dinnyési-Fertő & $1 \mathrm{ad}$ & Kiss Á., Szél L. \\
\hline 2006.11 .10 & Pusztaszer, Büdös-szék & 1 juv. & Nagy T. \\
\hline 2006.11 .11 & Balmazújváros, Virágoskúti-halastó & 7 & Varga L., Varga L. \\
\hline 2006.11 .11 & Geszt, Begécsi-víztároló & 2 ad. & Molnár Sz., Simay G., Vasas A. \\
\hline 2006.11 .13 & Pusztaszer, Büdös-szék & 2 ad. & Nagy $\mathrm{T}$. \\
\hline 2006.11 .14 & Pusztaszer, Büdös-szék & 1 ad. +1 juv. & Nagy $T$. \\
\hline 2006.11 .16 & Biharugra, Biharugrai-halastavak & $2 \mathrm{ad}$ & Tóth I., Tőgye J., \\
\hline 2006.11 .16 & Poroszló, Tisza-tó (Valki-medence) & $\begin{array}{l}3 \text { ad. }+1 \text { imm. }+3 \\
\text { juv. }\end{array}$ & Zalai T., Gál L. \\
\hline 2006.11 .16 & Poroszló, Tisza-tó (Valki-medence) & 3 ad. +3 juv. & Tar J. és társai \\
\hline 2006.11 .17 & Tata, Öreg-tó & $4 \mathrm{ad}$ & Csonka P. és társai \\
\hline 2006.11 .17 & Tömörkény, Csaj-tó & 2 ad. & Nagy T., Hajas G. \\
\hline 2006.11 .18 & Balmazújváros, Virágoskúti-halastó & 1 & Zalai T., Simay A. \\
\hline 2006.11 .18 & Fertőújlak & $1 \mathrm{ad}$ & Szász E., Szász Emese, Tamás Á. \\
\hline 2006.11 .19 & Biharugra, Biharugrai-halastavak & 4 ad. +4 imm. & Simay G., Seres N., Vince M. \\
\hline 2006.11 .19$. & Geszt, Begécsi-víztároló & $2 \mathrm{ad}$ & Simay G., Vince M. \\
\hline 2006.11.20. & Fertőújlak, Borsodi-dülő & 1 subad. & Hadarics T. \\
\hline 2006.11 .23 & Fertőújlak, Fésüs-sarok & $1 \mathrm{imm}$. & Pellinger A., Ferenczi M. \\
\hline 2006.11 .24 & Sarud, Kutyás & 1 ad. & Zalai T. \\
\hline 2006.11 .24 & Sarud, Török-föld & 2 ad. & Zalai T. \\
\hline 2006.11 .24 & Sarud, Nagy-állás & $1 \mathrm{ad}$ & Zalai T., Borbáth P. \\
\hline 2006.11 .25 & Biharugra, Biharugrai-halastavak & 5 ad. $+4 \mathrm{imm}$. & Molnár Sz., Vasas A. \\
\hline 2006.11 .25 & Geszt, Begécsi-víztároló & $1 \mathrm{ad}$ & Molnár Sz., Vasas A. \\
\hline 2006.11 .27 & Pusztaszer, Büdös-szék & $1 \mathrm{ad} .+1 \mathrm{imm}$. & Nagy T. \\
\hline 2006.11 .28 & Szabadszállás, Zab-szék & $2 \mathrm{ad}$ & Szél L. \\
\hline 2006.11 .28 & Fertőújlak, Fésüs-sarok & $1 \mathrm{ad}$ & Hadarics $\mathrm{T}$. \\
\hline 2006.12 .01 & Baks, baksi puszta & 2 ad. (1 pár) & Nagy T. \\
\hline 2006.12 .01 & Sarud, Falualja & $1 \mathrm{ad}$ & Zalai T. \\
\hline 2006.12 .03 & Geszt, Begécsi-víztároló & $5 \mathrm{ad} .+3 \mathrm{imm}$. & Molnár Sz., Seres N., Simay G., Vasas A. \\
\hline 2006.12 .04 & Dinnyés, Dinnyési-Fertő & $4 \mathrm{ad}$. & Ujvárosi Zs., Szász E. \\
\hline 2006.12.05. & Fertőújlak, Fésüs-sarok & 1 & Pellinger A. \\
\hline 2006.12.06-07. & Geszt, Begécsi-víztároló & 2 ad. & Simay G. \\
\hline 2006.12.07. & Tiszafüred, Sulymos & 3 ad. & Zalai T. \\
\hline 2006.12 .08 & Geszt, Begécsi-víztároló & 3 ad. & Seres N. \\
\hline 2006.12 .08 & Pély, Hatrongyos & 2 ad. & Borbáth P. \\
\hline 2006.12.09. & Geszt, Begécsi-víztároló & $2 \mathrm{ad}$ & Mazula A., Molnár Sz., Simay G., Vasas A. \\
\hline 2006.12 .09 & Tata, Öreg-tó & 1 ad. tojó & Csonka P., Sarlos F. \\
\hline 2006.12 .11 & Pély, Szarkás & $1 \mathrm{ad}$ & Zalai T., Rimóczi Á. \\
\hline 2006.12 .12 & Sarród, László-major & 1 ad. & Pellinger A. \\
\hline 2006.12 .15 & Poroszló, Kóta-dülő & 1 ad. & Zalai T. \\
\hline 2006.12 .21 & Pély, Gévai-puszta & 1 ad. & Zalai T. \\
\hline 2006.12 .22 & Darvas, Darvasi-halastavak & 3 ad. & Vasas A. \\
\hline 2006.12 .23 & Naszály, Ferencmajori-halastavak & 2 ad. & Csonka P., Dömsödi F. \\
\hline 2006.12 .27 & Kömlö, Csángó & $1 \mathrm{imm}$. & Zalai T. \\
\hline 2006.12 .27 & Nagyhegyes, Elepi-halastó & 1 & Seprényi A. \\
\hline 2006.12 .27 & Tarnaszentmiklós, Türügy-hát & $1 \mathrm{ad}$ & Borbáth P. \\
\hline 2006.12 .29 & Tarnaszentmiklós, Türügy-hát & 1 juv. & Zalai T. \\
\hline 2006.12 .30 & Debrecen, Ondód & $2 \mathrm{ad}$ & Seprényi A. \\
\hline 2007.01 .01 & Ópusztaszer, Csaj-hát & 1 ad. & Nagy T. \\
\hline 2007.01.01. & Tata, Öreg-tó & 1 & Szimuly Gy. \\
\hline 2007.01.02. & Ópusztaszer, Csaj-hát & $1 \mathrm{imm} .(2 \mathrm{y})$ & Nagy $T$. \\
\hline 2007.01.03. & Pély, Gévai-puszta & $1 \mathrm{imm}$ & Zalai T. \\
\hline 2007.01.06. & Debrecen, Ondód & $1 \mathrm{ad}$ & Gyüre P. \\
\hline 2007.01 .07 & Fertőújlak, Pap-rét & 1 & Pellinger A. \\
\hline 2007.01.08. & Kisköre, Rák-hát & 1 ad. & Zalai T. \\
\hline 2007.01.09. & Fertőújlak, Borsodi-dülő & $1 \mathrm{imm}$. & Pellinger A. \\
\hline 2007.01.09. & Sarud, Panyita & $1 \mathrm{ad}$ & Zalai T. \\
\hline 2007.01 .10 & Geszt, Begécsi-víztároló & 1 ad. & Simay G. \\
\hline 2007.01 .13 & Sarród, Lászlómajor & $1 \mathrm{imm}$. & Pellinger A. \\
\hline 2007.01 .15 & Fertőújlak, Borsodi-dülő & $1 \mathrm{imm}$. & Pellinger A. \\
\hline 2007.01 .15 & Poroszló, Tisza-tó & 1 & Németh F. \\
\hline 2007.01.20. & Átány, Belső-Szárazbő & 1 ad. & Zalai T. \\
\hline 2007.01.20. & Biharugra, Biharugrai-halastavak & 1 ad. & Simay G., Molnár Sz., Vasas A. \\
\hline 2007.01.20. & Fertőújlak, Pap-rét & $3 \mathrm{imm}$. & Pellinger A. \\
\hline 2007.01.20. & Hortobágy, Kun György-tó & 1 ad. & Gyüre P. \\
\hline 2007.01 .25 & Ópusztaszer, Csaj-hát & $\begin{array}{l}2 \text { ad. }+2 \text { ad. }+1 \mathrm{imm} \\
(2 \mathrm{y})\end{array}$ & 1.Nagy T. \\
\hline 2007.01 .25 & Pusztaszer, Büdös-szék & 2 ad. +1 imm. (2y) & Nagy $T$. \\
\hline 2007.01.26. & Hortobágy, Kun György-tó & $1 \mathrm{ad}$ & Gyüre P. \\
\hline 2007.01.27. & Baks, Pünkösd-hát & 2 ad. +1 imm. (3y) & Nagy T. \\
\hline 2007.01 .31 & Sarud, Tisza-tó (Sarudi-medence) & 2 & Rimóczi Á., Gődér R., \\
\hline 2007.02 .02 & Sarud, Török-föld & 1 ad. & Borbáth P. \\
\hline 2007.02 .05 & Hortobágy, Hortobágyi-halastó & 1 ad. & Papp G. \\
\hline 2007.02 .05 & Kömlö, Büdös-kút-dülő & 4 ad. & Zalai T. \\
\hline 2007.02 .05 & Szabadszállás, Zab-szék & $5 \mathrm{ad}$ & Kókay B. \\
\hline
\end{tabular}




\begin{tabular}{|c|c|c|c|}
\hline 2007.02 .06 & Darvas, Darvasi-halastavak & 1 ad. & Vasas A. \\
\hline 2007.02 .10 & Szabadszállás, Pipás-rét & 3 ad. & Valkó O., Pigniczki Cs., Kókay B. \\
\hline 2007.02 .10 & Szabadszállás, Kis-rét & 2 ad. & Valkó O., Pigniczki Cs., Kókay B. \\
\hline 2007.02 .10 & Tömörkény, Csaj-tó & 3 & Fodor A. \\
\hline 2007.02 .11 & Dunatetétlen, Bikatorok & 2 ad. & $\begin{array}{l}\text { Hegedüs D., Verseczki N., Pintér K., Pintér B., } \\
\text { Berényi Zs., Laposa D., Kókay B. }\end{array}$ \\
\hline 2007.02 .13 . & Hortobágy, Árkus & 1 ad. & Kovács G., Kovács G. K. \\
\hline 2007.02 .14 & Poroszló, Tisza-tó (Valki-medence) & 2 ad. & Gődér R., Rimóczi Á. \\
\hline 2007.02 .15 & Egyek & 3 & Vass B. \\
\hline 2007.02 .15 . & Fertőújlak, Borsodi-dűlő & 2 ad. +2 ad. +1 ad. & Pellinger A. \\
\hline 2007.02 .19 & Fertőszéplak, Széplaki-legelő & $2 \mathrm{ad}$ & Pellinger A., Tamás Á. \\
\hline 2007.02 .20 & Darvas, Csiff & $1 \mathrm{ad}$. & Vasas A. \\
\hline 2007.02 .20 & Sarród, Bő-Sarród & 3 ad. & Pellinger A. \\
\hline 2007.02.21. & Sarud, Tisza-tó (Sarudi-medence) & $1 \mathrm{ad}$. & Szilágyi A. \\
\hline $2007.02 .24-25$. & Geszt, Begécsi-víztároló & $1 \mathrm{ad}$. & Vasas A.; Molnár Sz., Vasas A. \\
\hline 2007.02.24. & Kardoskút, Fehér-tó & 1 ad. & Barkóczi Cs., Baranyai A., Szakács I. \\
\hline 2007.02 .25 & Biharugra, Fertály & 3 ad. & Molnár Sz., Vasas A. \\
\hline 2007.02 .25 & Sarród, Gagarin-major & 2 ad. & $\begin{array}{l}\text { Pellinger A., Szász E., Kárász B., Benei Zs., } \\
\text { László Cs., Ferenczi M., Tamás Á. }\end{array}$ \\
\hline 2007.02.26. & Sarród, Bő-Sarród & $\begin{array}{l}2 \text { ad. }+2 \text { ad. }+2 \text { ad. }+ \\
1 \mathrm{imm} .+1 \mathrm{imm} .\end{array}$ & Pellinger A. \\
\hline 2007.02 .26 & Sarud, Felsö-Daru-hát & $1 \mathrm{ad}$ & Zalai T. \\
\hline 2007.02.26. & Sarud, Panyita & $1 \mathrm{ad}$ & Zalai T. \\
\hline 2007.02 .27 & Sarród, Bő-Sarród & 2 ad. +1 ad. +1 ad. & Pellinger A. \\
\hline 2007.02 .28 & Sarród, Bő-Sarród & 1 ad. +4 juv. & Pellinger A., Ferenczi M. \\
\hline 2007.02 .28 & Sarud, Alsó-Daru-hát & $1 \mathrm{ad}$ & Zalai T. \\
\hline 2007.03 .01 & Darvas, Csiff & 2 ad. & Vasas A. \\
\hline 2007.03.01. & Pusztaszer, Büdös-szék & $\begin{array}{l}2 \text { ad. }+1 \text { ad. }+1 \mathrm{imm} \\
(2 \mathrm{y})+2 \text { ad. }+1 \mathrm{imm} . \\
(2 \mathrm{y})\end{array}$ & Nagy T. \\
\hline 2007.03 .01 & Sarród, Bő-Sarród & 2 ad. +4 imm. & Pellinger A., Ferenczi M., Tatai S. \\
\hline 2007.03 .03 . & Fertőújlak, Nyéki-szállás & $1 \mathrm{ad}$ & Kiss T., László Cs., Nagy Á., Tamás Á. \\
\hline 2007.03 .03 . & Geszt, Begécsi-víztároló & 2 ad. & Vasas A. \\
\hline 2007.03 .03 . & Hortobágy, Hortobágyi-halastó & 4 & Gyüre P. \\
\hline 2007.03 .04 . & Geszt, Begécsi-víztároló & 1 ad. & Vasas A. \\
\hline 2007.03 .05 . & Apaj, Apaj-puszta & 1 ad. & Kókay B. \\
\hline 2007.03 .05 & Sarród, Bő-Sarród & $1 \mathrm{ad}$. & Pellinger A. \\
\hline 2007.03 .08 & Apaj, Apaj-puszta & 1 & Kókay B. \\
\hline 2007.03 .09 & Hortobágy, Szász-telek & 3 ad. & Gyüre P. \\
\hline 2007.03 .09 . & Tiszacsege, Kecskés & 1 ad. & Gyüre P. \\
\hline 2007.03 .11 & Geszt, Begécsi-víztároló & 3 ad. & Vasas A., Molnár Sz. \\
\hline 2007.03 .12 & Tiszasüly, Belső-rét & $1 \mathrm{ad}$ & Zalai T. \\
\hline 2007.03 .13 . & Apaj, Alsó-Szúnyog & 3 ad. +2 ad. +1 ad. & Kókay B. \\
\hline 2007.03.13. & Hortobágy, Hortobágyi-halastó (Kondás) & 5 ad. +3 ad. & Papp G. \\
\hline $2007.03 .13-15$. & Fertőújlak, Borsodi-dűlő & 1 ad. & Pellinger A. \\
\hline 2007.03 .15 & Apaj, Alsó-Szúnyog & 2 ad. & Kókay B., Laposa D., Lendvai Cs. \\
\hline 2007.03 .15 & Hortobágy, Kun György-tó & 2 ad. & Gyüre P. \\
\hline 2007.03 .16 & Fertőújlak, Pap-rét & 1 & Pellinger A., Ferenczi M., Kraft Gy. \\
\hline 2007.03 .16 & Hortobágy, Hortobágyi-halastó (Kondás) & $\begin{array}{l}1 \text { ad. hím }+2 \text { ad. tojó } \\
+1 \text { ad. }\end{array}$ & Barkóczi Cs., Kiss Zs. \\
\hline 2007.03 .17 & Apaj, árasztások & 1 & Takács Á. \\
\hline 2007.03.22. & Fertőújlak, Fésűs-sarok & 8 & Pellinger A., Tamás Á. \\
\hline 2007.03 .24 & Fertőújlak, Cikes & 2 & Pellinger A., Ferenczi M. \\
\hline 2007.03 .25 & Hortobágy, Kun György-tó & 36 & Emri T., Gyüre P., Zöld B. \\
\hline 2007.03.31. & Hortobágy, Hortobágyi-halastó (Kondás) & 40 & $\begin{array}{l}\text { Bodor G., Horváth G., Kóta A., Selmeczi } \\
\text { Kovács A. }\end{array}$ \\
\hline 2007.04 .02 . & Hortobágy, Hortobágyi-halastó (Kondás) & 43 & Balázsi P., Gilányi G. \\
\hline 2007.04 .06 & Hortobágy, Hortobágyi-halastó (Kondás) & 32 & Kovács G., Kovács G. K. \\
\hline 2007.04 .14 & Hortobágy, Hortobágyi-halastó & 28 & Gyüre P. \\
\hline
\end{tabular}

\subsection{Indiai lúd (Anser indicus)}

2007 januárjának közepén a pusztaszeri Büdös-széken bukkant fel egy öreg madár, majd valószínűleg ugyanezt a példányt látták az Alföld más területein is a későbbiekben (egészen február második hetéig). Az adatokat (egy madár több előfordulásaként) $\mathrm{C}$ kategóriásnak fogadta el a Nomenclator Bizottság, azaz a madár valószínúleg az Európában költő populációból származott, és a vonuló vadludak csapataival került a Kárpát-medencébe.

$\begin{array}{llll}\text { 2007.01.14. } & \text { Pusztaszer, Büdös-szék } & 1 \text { ad. (C) } & \text { Taschek M., Zádori Á. } \\ \text { 2007.01.20-21. } & \text { Komádi, Úsztató-dúlö } & 1 \text { ad. (C) } & \begin{array}{l}\text { Seres N., Ványi R., Simay G., Molnár Sz., Vasas } \\ \text { A. }\end{array} \\ \text { 2007.02.02. } & \text { Nagyhegyes, Vajda-lapos } & 1 \text { ad. (C) } & \text { Tar J., Szilágyi A. }\end{array}$




\subsection{Kanadai lúd (Branta canadensis)}

Minden hitelesített előfordulás során a törzsalak (ssp. canadensis) került szem elé. A 2006 júliusában a Fertő térségében megfigyelt madár adatait a Nomenclator Bizottság $D_{E}$ kategóriásnak fogadta el, azaz a madár eredete kétséges, de valószínübbnek látszik elsősorban a nyár közepi előfordulás miatt - a fogságból való szökés. Ugyanígy $\mathrm{D}_{\mathrm{E}}$ kategóriásként kerül elfogadásra a 2007 áprilisában Abán látott példány. A 2006 novemberében a geszti Begécsi-víztárolón, illetve a decemberben a Kis-Balatonon megfigyelt egy-egy példány adatait a Nomenclator Bizottság $\mathrm{C}$ kategóriába fogadta el, azaz a madarak nagy valószínüséggel az Európában szabadon költő populációból származhattak, és a vonuló vadlúdtömegekkel együtt kerülhettek a Kárpát-medencébe.

\begin{tabular}{|c|c|}
\hline 2006.07.09.* & Fertőrákos, Fertő (Rákosi-öböl) \\
\hline 2006.07.10-11. & Fertőújlak, Borsodi-dülö \\
\hline 2006.11 .11 . & Geszt, Begécsi-víztároló \\
\hline 2006.11.19.* & Biharugra, Biharugrai-halastavak \\
\hline $2006.11 .24-25$. & Geszt, Begécsi-víztároló \\
\hline 2006.12 .11 & Zalavár, Kis-Balaton \\
\hline 2006.12.12.* & Sarród, László-major \\
\hline 2007.04.21. & Aba, Holdvilág-tó \\
\hline
\end{tabular}

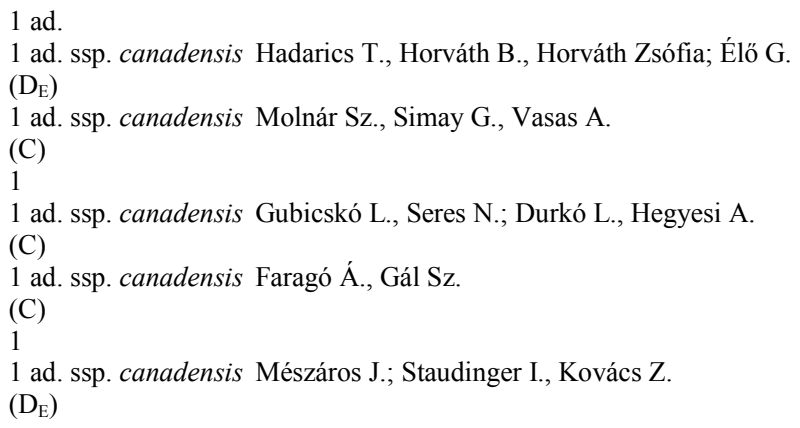

\subsection{Apácalúd (Branta leucopsis)}

Az apácalúd előfordulásai az utóbbi években megszaporodtak, szinte minden nagyobb vadlúd-gyülekezőhelyen megfigyelték már más vadludak csapataival tartó példányait. A 2006 őszén és telén a Hortobágyon és a Tisza-tavon megfigyelt 5-7 példány eredete kérdéses, elképzelhető, hogy nem vad eredetü madarakról van szó. Valószínűleg ugyanezek a madarak (4-5 példány) tüntek ott fel 2007 tavaszán (március-április) is a Hortobágyon, illetve később (május) Apajon is (4 példány). Ténylegesen vad eredetü apácaludak október közepén (Fertőújlak) jelentek meg elöször a szezonban. A szezon során az országban többfelé is elökerült egy-egy (legfeljebb három) példány. Az utolsókat márciusban látták, de egy öreg madár még május végén is felbukkant Fertőújlakon. Egyegy madarat többször is megfigyeltek ugyanazon a területen.

\begin{tabular}{|c|c|}
\hline 2006.09 .26 & Tiszafüred, Egyek-Pusztakócsi-mocsarak \\
\hline 2006.10 .13 . & Fertőújlak, Borsodi-dülő \\
\hline 2006.10 .14 . & Fertőújlak, Borsodi-dülő \\
\hline 2006.10.21. & Bősárkány, Nyirkai-Hany \\
\hline 2006.10 .23 & Bősárkány, Nyirkai-Hany \\
\hline 2006.10 .26 . & Bősárkány, Nyirkai-Hany \\
\hline 2006.11 .01 . & Egyek \\
\hline 2006.11 .06 . & Tiszafüred, Jusztus \\
\hline 2006.11 .07$. & Fertőújlak, Borsodi-dűlő \\
\hline 2006.11 .07$. & Poroszló, Tisza-tó (Valki-medence) \\
\hline 2006.11 .08 . & Dinnyés, Dinnyési-Fertő \\
\hline 2006.11 .10 . & Poroszló, Tisza-tó (Valki-medence) \\
\hline 2006.11 .11 . & Dinnyés, Dinnyési-Fertő \\
\hline 2006.11 .11 . & Dinnyés, Dinnyési-halastavak \\
\hline 2006.11 .12 . & Dinnyés, Dinnyési-Fertő \\
\hline 2006.11.12. & Poroszló, Tisza-tó (Valki-medence) \\
\hline $2006.11 .13-14$. & Poroszló, Tisza-tó (Valki-medence) \\
\hline 2006.11.15. & Balmazújváros, Virágoskúti-halastó \\
\hline 2006.11 .16 . & Balmazújváros, Virágoskúti-halastó \\
\hline 2006.11 .16$. & Fertőújlak, Borsodi-dűlő \\
\hline 2006.11 .17$. & Fertőújlak, Borsodi-dülő \\
\hline 2006.11 .18 . & Balmazújváros, Virágoskúti-halastó \\
\hline 2006.11 .18 . & Balmazújváros, Virágoskúti-halastó \\
\hline 2006.11 .19 . & Balmazújváros, Virágoskúti-halastó \\
\hline
\end{tabular}

$\begin{array}{ll}5 & \text { Nagy G. G. } \\ 2 & \text { Pellinger A. } \\ 2 & \text { Kárász B., Ballmann M., Benei Zs., Tamás Á. } \\ 2 & \text { Ferenczi M., Tomor Á. } \\ 2 & \text { Ferenczi M., Tomor Á. } \\ 2 & \text { Pellinger A., Ferenczi M. } \\ 6 & \text { Seprényi A. } \\ 6 & \text { Seprényi A. } \\ 2 \text { ad. } & \text { Fehér F., Juhász I. } \\ 6 & \text { Zalai T. } \\ 1 \text { ad. } & \text { Kiss Á., Szél L. } \\ 6 & \text { Tar J., Zalai T. } \\ 3 & \text { Szegedy I., Bajor Z., Juhász I. és mások } \\ 2 \text { ad. } & \text { Szeghalmi J. társai } \\ 2 & \text { Vasuta G. } \\ 5 & \text { Nagy G. G., Rimóczi Á., Gődér R. } \\ 3 & \text { Zalai T.; Nehézy L. } \\ 1 & \text { Tihanyi G., Ecsedi Z., Tar J., Szilágyi A., Zalai T., } \\ 9 & \text { Borza S. } \\ 1 & \text { Tar J., Szilágyi A., Borza S. } \\ 1 & \text { Pellinger A., Ferenczi M. } \\ 3 & \text { Szolnyik Cs. } \\ 4+2 & \text { Simay A., Tar J., Zalai T. } \\ 5 & \text { Weszelinov O., Koczka A. } \\ & \text { Berényi Zs., Bodor G., Hegedüs D., Kókay B., Laposa }\end{array}$


2006.11.19.

2006.11.26.

2006.11 .27 .

2006.12.03.

2006.12.06.

2006.12.07.

2006.12.07.

2006.12.08.

2006.12.10.

2006.12.12.

2006.12 .12

2006.12.12.

2006.12.13.

2006.12.14.

2006.12.17.

2006.12.20.

2006.12.20.

2006.12.21.

2006.12.22.

2006.12.23.

2006.12.25.

2006.12.26.

2006.12.27.

2006.12.29.

2007.01.01.

2007.01.02.

2007.01 .03 .

2007.01.03.

2007.01 .08 .

2007.01.09.

2007.01.11.

2007.01.12.

2007.01.15.

2007.01 .16 .

2007.01.21.

2007.01.27.

2007.01 .31 .

2007.01.31.

2007.02 .01 .

2007.02.01.

2007.02.05.

2007.02 .05 .

2007.02.14.

2007.02 .15 .

2007.02.18.

2007.02.19.

2007.02.21.

2007.02.23.

2007.02.24.

2007.02.25.

2007.02.25.

2007.02.26.

2007.03.03.

2007.03 .03 .

2007.03.11.

2007.03.13.

2007.03 .16 .

2007.03.16.

2007.03.29.

2007.03.31-04.01.

2007.04.02.

2007.04.06-08.

2007.04.18.

2007.04.21.

2007.05.04-06.

2007.05 .08 .

2007.05.10.

2007.05.20.

2007.05.27.

2007.05.29.

2007.06.06.

2007.06.08-09.
Hajdúböszörmény

Hegyeshalom, Csemez-tanya

Tata, Öreg-tó

Nyergesújfalu, Duna (Nyerges-sziget)

Fonyód

Kömlőd, Mihály-patak-dülő

Pély, Hatrongyos

Hortobágy, Máta

Fertőújlak, Fésűs-sarok

Pély, Hatrongyos

Poroszló, Kóta-dülő

Tata, Öreg-tó

Fertőújlak, Nyéki-szállás

Sarród, Gagarin-major

Abádszalók, Tisza-tó (Abádszalóki-öböl)

Kisköre, Tisza-rét-dűlő

Pély, Gévai-puszta

Pély, Gévai-puszta

Tata, Öreg-tó

Tata, Öreg-tó

Abádszalók, Tisza-tó (Abádszalóki-öböl)

Tarnaszentmiklós, Türügy-hát

Tarnaszentmiklós, Türügy-hát

Geszt, Begécsi-víztároló

Tarnaszentmiklós, Türügy-hát

Abádszalók, Tisza-tó (Abádszalóki-öböl)

Tarnaszentmiklós, Nagy-fenék

Jászkisér, Pusztakürt

Fertőújlak, Borsodi-dülő

Fertőújlak, Fésüs-sarok

Fertőújlak, Borsodi-dülő

Poroszló, Tisza-tó (Valki-medence)

Fertőújlak, Nyéki-szállás

Tata, Öreg-tó

Sarród, László-major

Fertőújlak, Borsodi-dülő

Poroszló, Tisza-tó (Valki-medence)

Pinnye

Sarud, Szérük laposa

Kömlö, Büdös-kút-dülö

Szabadszállás, Zab-szék

Poroszló, Tisza-tó (Valki-medence)

Geszt, Begécsi-víztároló

Pákozd

Sarud, Tisza-tó (Sarudi-medence)

Dinnyés, Elza-major

Tiszanána, Bodzás

Geszt, Begécsi-víztároló

Biharugra, Fertály

Sarud, Tisza-tó (Sarudi-medence)

Sarud, Felső-Daru-hát

Geszt, Begécsi-víztároló

Hortobágy, Hortobágyi-halastó

Geszt, Begécsi-víztároló

Hortobágy, Hortobágyi-halastó (Kondás)

Dinnyés, Dinnyési-Fertő

Hortobágy, Hortobágyi-halastó (Kondás) 4 ad.

Hortobágy, Hortobágyi-halastó (Kondás) 4

Hortobágy, Hortobágyi-halastó (Kondás) 4

Hortobágy, Hortobágyi-halastó (Kondás) 5 Hortobágy, Hortobágyi-halastó (Kondás) 5 ad.

Hortobágy, Hortobágyi-halastó 5

Tiszafüred, Meggyes-lapos

Apaj, árasztások

Hortobágy, Máta

Tiszafüred, Kis-Jusztus

Apaj, Alsó-Szúnyog

Apaj, Alsó-Szúnyog

Fertő́jlak, Pap-rét

Apaj, halastavak

Apaj, Szúnyog-puszta
D. és mások

Gyüre P.

Tar J. és mások

Spakovszky P.

Szimuly Gy., Musicz L., Szimuly Sz.

Csonka P.

Nagy L.

Csonka P.

Borbáth P.

Vasas A., Mazula A., Molnár Sz., Simay G., Simay A.

Pellinger A.

Borbáth P.

Zalai $\mathrm{T}$.

Csonka P.

Hadarics T.

Pellinger A.

Zalai T.

Borbáth P.

Zalai T.

Borbáth P.

Musicz L., Hegyi Z.

Riezing N.

Bodzás J., Kovács B., Szepesváry Cs., Kiss Á.

Borbáth $\mathrm{P}$.

Zalai T., Borbáth P.

Vasas A., Molnár Sz.. Mazula A.

Borbáth P.

Zalai T.

Borbáth P., Zalai T.

Zalai T.

Pellinger A.

Pellinger A., Szolnyik Cs.

Pellinger A., Ferenczi M.

Zalai $\mathrm{T}$.

Pellinger A.

Szimuly Gy., Szimuly Sz., Szimuly D.

Pellinger A.

Pellinger A.

Gődér R., Rimóczi Á.

Mogyorósi S

Ferenc A.

Zalai $\mathrm{T}$.

Kókay B.

Gődér R., Rimóczi Á.

Seres N.

Hegedüs D., Laposa D., Kókay B.

Gődér R., Rimóczi Á.

Vasuta G., Kocsis K.

Fatér I.

Mazula A., Molnár Sz., Vasas A.

Molnár Sz., Vasas A.

Steiner A.

Zalai T.

Molnár Sz., Vasas A

Gyüre P.

Vasas A., Molnár Sz., Tóth I., Seres N. és társaik

Papp G.

Kotán E., Zsoldos Cs.

Barkóczi Cs., Kiss Zs.; Ecsedi Z., Simay A.

Nagy G. G.

Bodor G., Horváth G., Kóta A., Selmeczi Kovács Á.;

Weszelinov O., Pánya Cs., Koczka A.

Balázsi P., Gilányi G.

Kovács G., Kovács G. K.; Nagy M.; Kiss Á., Kardos É., Kiss J.

Balázsi P.

Pécsi L., Kovács G. és társaik

Szél L., Kiss Á.; Bodor G., Katona I., Vámosi K.;

Mészáros J., Barna M., Takács A.

Takács Á., Szél L., Kiss Á.

Cser Sz., Faragó Á.

Hegedüs D., Lendvai Cs.

Fodor A., Lendvai Cs.

Pellinger A., Tamás Á.

Györfy $\mathrm{H}$.

Kóta A., R. Gunkel; Gránicz L., Forintos N. 
2007.06.16. Apaj, árasztások 2007.06.23. Apaj, árasztások $\begin{array}{ll}4 & \text { Lendvai Cs., Hegedüs D. } \\ 3 \text { ad. } & \text { Abonyi O., Juhász I., Lovas A. }\end{array}$

\subsection{5. Örvös lúd (Branta bernicla)}

Valamennyi adata a törzsalakra (ssp. bernicla) vonatkozik. Először október utolsó harmadában bukkant fel egy fiatal madár a tiszasülyi Homori-halastavakon, majd október végétől többször láttak egy öreg példányt a Tisza-tavon és a balmazújvárosi Virágoskútihalastavon, a térségben több példány is mozgott, hiszen hol itt, hol ott bukkant fel egy-egy (vagy két) madár, sőt 2006. november 15-én a Virágoskúti-halastavon két öreg és egy fiatal példányt láttak egyszerre. A Fertő környékéről csak december elejéröl ismert két, valószínúleg ugyanarra a példányra vonatkozó adat. Decemberben és márciusban a geszti Begécsi-víztárolón, februárban pedig a dunatetétleni Böddi-széken is láttak egy-egy példányt.

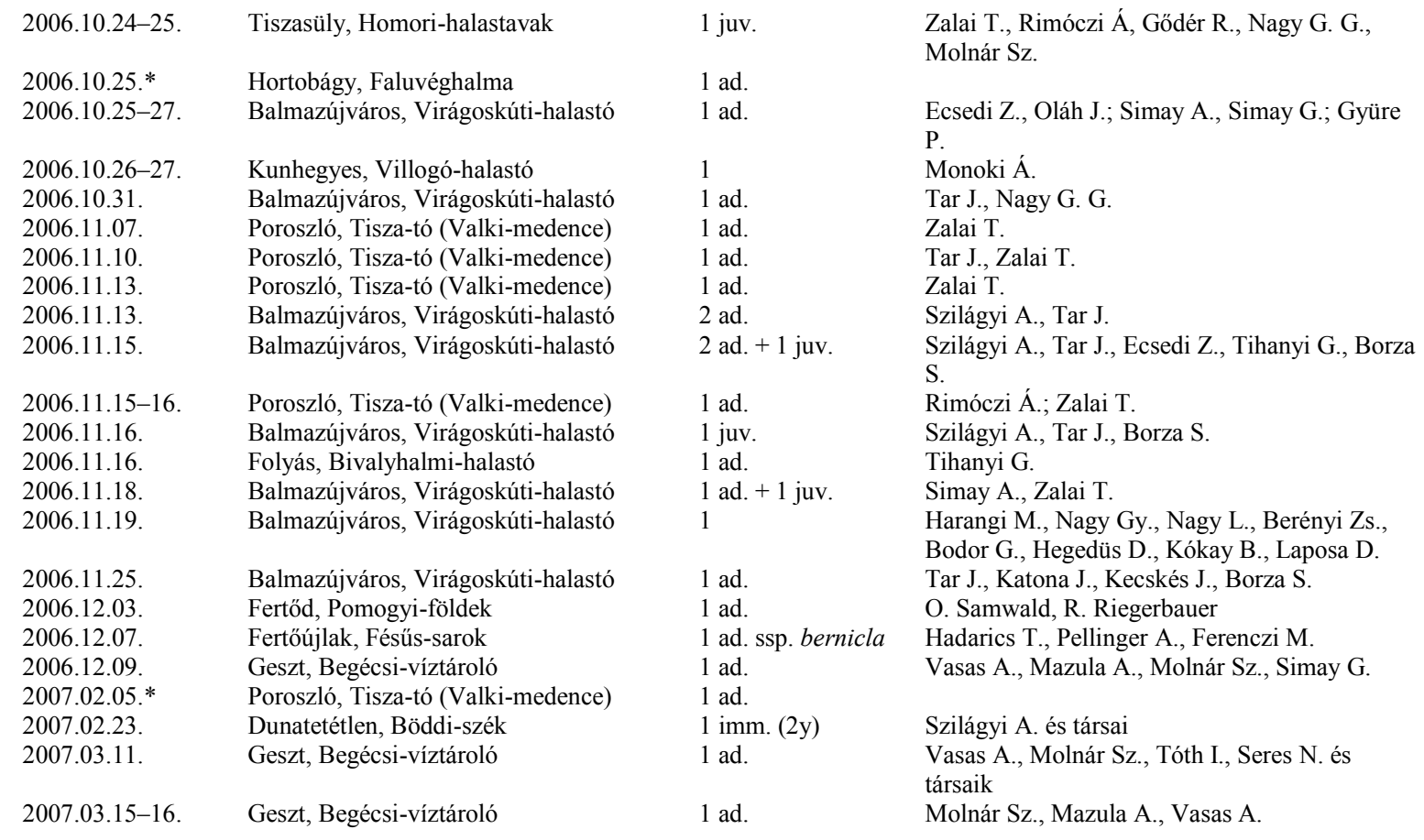

\subsection{Vörösnyakú lúd (Branta ruficollis)}

Első megfigyelése október közepéről származik, zömük október végén, november első felében érkezett a Kárpát-medencébe, ahol október végétől február végéig - de szórványosan még március első felében is - folyamatosan meg lehetett figyelni a vadlúdgyülekezőhelyeken. Az őszi előfordulások zöme novemberre esett. A legtöbb adat az Alföldről származik, de a Dunántúl néhány pontján (Fertő környéke, Hanság, Rétszilas, Tata térsége) is látták. Általában kisebb, 2-10 példányból álló csapatokban mutatkozott, melyek többnyire nagy lilikek tömegeiben vegyültek el, de néhány esetben 15-28 példányos csapatok is felbukkantak (Hortobágy, Tisza-tó). 28 példányból álló csaaptot két különböző helyen és időben is láttak: 2006. november 10. Tisza-tó; 2006. december 8. Szabadszállás. Kiemelendő, hogy a 2006. november 24-én Sarud határában (Kutyás) látott három példány közül az egyik madár sötét, melanisztikus színezetü példány volt.

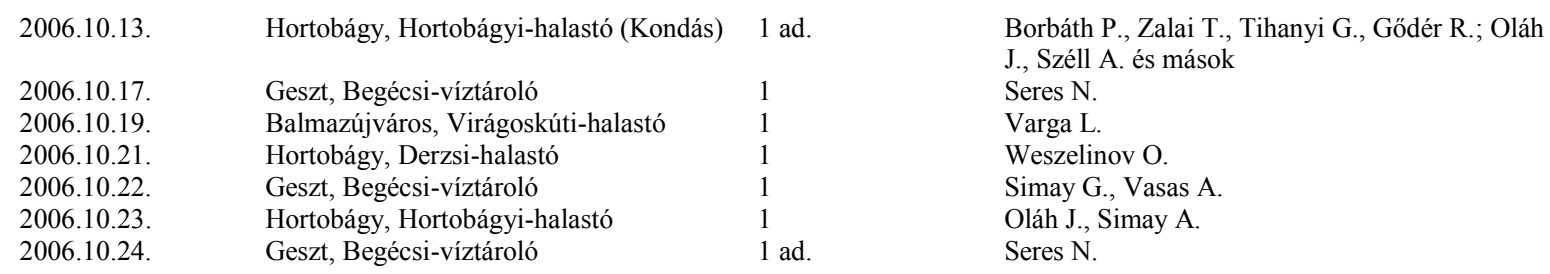


2006.10.25.

2006.10.27.

2006.10.27.

2006.10.27.

2006.10.27.

2006.10.27.

2006.10 .28

2006.10.28.

2006.10.31.

2006.10.31.

2006.11.01.

2006.11.03.

2006.11.03.

2006.11.04.

2006.11.06.

2006.11.07.

2006.11.07.

2006.11.08.

2006.11.08.

2006.11.10.

2006.11.10.

2006.11.11.

2006.11.11.

2006.11.11.

2006.11.12.

2006.11.13.

2006.11 .13

2006.11.14.

2006.11.14.

2006.11.14.

2006.11.15.

2006.11.15.

2006.11.15.

2006.11.16.

2006.11.16.

2006.11 .16 .

2006.11.18.

2006.11.18.

2006.11.18.

2006.11.19.

2006.11.19.

2006.11.19.

2006.11.19.

2006.11.19.

2006.11.19.

2006.11.19.

2006.11.21.

2006.11.22.

2006.11.24.

2006.11.24.

2006.11.25.

2006.11.25.

2006.11.26.

2006.11.26.

2006.11.26.

2006.11.26.

2006.11.27.

2006.11.27.

2006.11.28.

2006.12.01.

2006.12.01.

2006.12.02.

2006.12.02.

2006.12 .02 .

2006.12.03.

2006.12.03.

2006.12.03.

2006.12.06.

2006.12.06.

2006.12.06-07.

2006.12.07.

2006.12.07.
Balmazújváros, Virágoskúti-halastó Balmazújváros, Virágoskúti-halastó

Egyek, Ohati-halastó

Hortobágy, Csécsi-halastó

Hortobágy, Faluvéghalma

Pusztaszer, Büdös-széki-puszta

Hortobágy, Csécsi-halastó

Hortobágy, Lyukas-halom

Balmazújváros, Virágoskúti-halastó

Tata, Öreg-tó

Egyek

Poroszló, Tisza-tó

Sarud, Daru-hát

Pusztaszer, Büdös-szék

Hortobágy, Ohat

Sarud, Dinnyés-hát

Tata, Öreg-tó

Geszt, Begécsi-víztároló

Pusztaszer, Büdös-szék

Poroszló, Tisza-tó (Valki-medence)

Pusztaszer, Büdös-szék

Balmazújváros, Virágoskúti-halastó

Bősárkány, Nyirkai-Hany

Geszt, Begécsi-víztároló

Poroszló, Tisza-tó (Valki-medence)

Poroszló, Tisza-tó (Valki-medence)

Pusztaszer, Büdös-szék

Mosonszolnok

Poroszló, Tisza-tó

Pusztaszer, Büdös-szék

Balmazújváros, Virágoskúti-halastó

Fertőújlak, Borsodi-dülő

Poroszló, Tisza-tó (Valki-medence)

Balmazújváros, Virágoskúti-halastó

Biharugra, Biharugrai-halastavak

Poroszló, Tisza-tó (Valki-medence)

Balmazújváros, Virágoskúti-halastó

Poroszló, Tisza-tó

Soponya, Soponyai-halastavak

Biharugra, Biharugrai-halastavak

Egyek, Jusztus

Geszt, Begécsi-víztároló

Hajdúböszörmény

Poroszló, Tisza-tó (Valki-medence)

Rétszilas, Rétszilasi-halastavak

Sarud, Tisza-tó (Sarudi-medence)

Biharugra, Biharugrai-halastavak

Sarud, Tisza-tó (Sarudi-medence)

Fertőújlak, Borsodi-dülő

Sarud, Kutyás

Balmazújváros, Virágoskúti-halastó

Geszt, Begécsi-víztároló

Balmazújváros, Virágoskúti-halastó

Egyek, Jusztus

Tiszafüred, Meggyes-lapos

Tiszavasvári, Fehér-szik

Hegyeshalom, Csemez-tanya

Pusztaszer, Büdös-szék

Szarvas, Holt-Körös

Sarud, Kutyás

Tiszaderzs

Balmazújváros, Virágoskúti-halastó

Békés, halastavak

Geszt, Begécsi-víztároló

Geszt, Begécsi-víztároló

Szabadszállás, Zab-szék

Tata, Öreg-tó

Geszt, Begécsi-víztároló

Poroszló, Tisza-tó (Valki-medence)

Tata, Öreg-tó

Geszt, Begécsi-víztároló

Szeged, Szegedi-Fertő
$1 \mathrm{ad}$.

2

4

9 ad. +1 imm

3 ad. +1 juv.

8 ad. +1 juv.

$1 \mathrm{ad}$.

3

1 juv.

16

1 juv

1 ad.

3 ad. +1 juv.

28

2 ad. +2 juv.

10

21

10

2

6

15

$4+3$

12

$1 \mathrm{ad}$.

1 juv.

7

15

10

1

$2 \mathrm{imm}$.

3 ad.

2 ad.

7

példány is van

közöttük)

1

8

8

1

5

5

1

5 ad.

2

3

$9+5$

4

21

3

4

27
Ecsedi Z., Oláh J.

Simay G.

Végvári Zs.

Végvári Zs.

Gyüre P.

Nagy $T$.

Járosi A., Kovács G. K.

Járosi A., Kovács G. K.

A. L., Nagy G. G.

Csonka P.

Seprényi A.

Pánya Cs.

Zalai T.

Nagy T. és társai

Seprényi A.

Borbáth P., Zalai T.

Csonka P.

Tóth I.

Nagy T.

Tar J., Zalai T.

Nagy T.

Varga L., Varga L.

Ferenczi M., Tomor Á.

Molnár Sz., Simay G., Vasas A.

Gődér R., Nagy G. G., Rimóczi Á,

Zalai $\mathrm{T}$.

Nagy T.

Spakovszky $\mathrm{P}$.

Nehézy L.

Nagy T.

Ecsedi Z., Tar J., Szilágy A., Tihanyi G., Zalai

T., Borza S.

Agócs P.

Rimóczi A.

Tar J., Szilágyi A., Borza S.

Seres N., Tóth I., Tőgye J.

Zalai T., Gál L.

Weszelinov O., Koczka A.

Steiner A., Verseczki N., Pintér B., Rimóczi Á.

Schmotzer A., Tóth L.

Bodor G., Horváth G., Porkoláb M.

Simay G., Vince $\mathrm{M}$.

Seprényi A., Nagy A.

Simay G., Vince M.

Gyüre P.

Steiner A.

Mészáros J., Staudinger I., Nagy I.

Rimóczi Á.

Seres N.

Borbáth $\mathrm{P}$

Pellinger A., Ferenczi M

Zalai T.

Borza S., Tar J., Katona J., Kecskés J., Molnár Sz., Seres N., Tóth I., Vasas A.

Tar J. és mások

Seprényi A.

Kiss B.

Simon Gy.

Spakovszky P.

Nagy $T$.

Nagy S., Grecs A.

Borbáth P., Zalai T.

Oláh J.

Borza S., Harangi S., Katona J.

Durkó L.

Vasas A., Mazula A., Molnár Sz., Simay G.

Molnár Sz., Seres N., Simay G., Vasas A.

Hegedüs D., Kókay B.

Szimuly Gy., Musicz L., Szimuly Sz.

Simay G.

Borbáth P.

Csonka P.; Szimuly Gy., Csonka P.

Simay G., Tóth I.

Hajas G. 


\begin{tabular}{|c|c|c|c|}
\hline 2006.12.07. & Tiszafüred, Sulymos & 1 juv. & Zalai T. \\
\hline 2006.12.08. & Geszt, Begécsi-víztároló & 21 & Seres N. \\
\hline 2006.12.08. & Pély, Hatrongyos & 5 & Borbáth P. \\
\hline 2006.12.08. & Poroszló, Tisza-tó & 4 & Pánya Cs. \\
\hline 2006.12.08. & Szabadszállás, Zab-szék & 28 & Klein Á., Miholcsa T., Szász E. \\
\hline 2006.12.09. & Geszt, Begécsi-víztároló & 19 & Mazula A., Molnár Sz., Simay G., Vasas A. \\
\hline 2006.12.09. & Tata, Öreg-tó & 2 & Csonka P., Sarlos F. \\
\hline 2006.12.10. & Fülöpszállás, Kelemen-szék & $1 \mathrm{ad}$. & Zsoldos M., Kókay Sz. \\
\hline 2006.12.10. & Nagyhegyes, Elepi-halastó & 1 ad. & $\begin{array}{l}\text { Bodor G., Horváth G., Kóta A., Porkoláb M., } \\
\text { Ungi B. }\end{array}$ \\
\hline 2006.12.10. & Tata, Öreg-tó & 4 & Szimuly Sz., Szimuly Gy., Szimuly D. \\
\hline 2006.12.11. & Fertő́ujlak, Nyéki-szállás & 2 & Pellinger A. \\
\hline 2006.12.11. & Pusztaszer, Büdös-szék & 8 & Nagy T. \\
\hline 2006.12.11. & Szabadszállás, Büdös-szék & $1 \mathrm{ad}$. & Kókay Sz. \\
\hline 2006.12.12. & Fertőújlak, Fésűs-sarok & 4 & Pellinger A. \\
\hline 2006.12.12. & Pély, Hatrongyos & 1 juv. & Borbáth P. \\
\hline 2006.12.12. & Poroszló, Cigány-dủlő & 11 & Zalai T. \\
\hline 2006.12.12. & Poroszló, Kóta-dülő & 6 & Zalai $\mathrm{T}$. \\
\hline 2006.12.13. & Naszály, Ferencmajori-halastavak & $1 \mathrm{ad}$. & Csonka P., Szimuly Gy. \\
\hline 2006.12.13. & Poroszló, Felső-járás & 13 & Zalai T. \\
\hline 2006.12.13. & Tata, Öreg-tó & 4 & Csonka P. \\
\hline 2006.12.14. & Fertő́ujlak, Nyéki-szállás & $1 \mathrm{ad}$. & Hadarics T. \\
\hline 2006.12.14. & Naszály, Ferencmajori-halastavak & 2 ad. & Csonka P. \\
\hline 2006.12.15. & Poroszló, Kóta-dülő & 10 & Zalai T. \\
\hline 2006.12 .16 & Fertőújlak, Nyéki-szállás & $1 \mathrm{ad}$ & Pellinger A. \\
\hline 2006.12.17. & Sarród, Gagarin-major & 2 ad. $+1 \mathrm{imm}$. & Pellinger A. \\
\hline 2006.12.18. & Fertöújlak, Fésűs-sarok & $1 \mathrm{imm}$. & Pellinger A. \\
\hline 2006.12.20. & Geszt, Begécsi-víztároló & $2 \mathrm{ad}$. & Seres N. \\
\hline 2006.12.20. & Kisköre, Tisza-rét-dűlő & 1 juv. & Borbáth P. \\
\hline 2006.12.20. & Sarud, Panyita & 2 juv. & Zalai T. \\
\hline 2006.12.21. & Geszt, Begécsi-víztároló & $1 \mathrm{ad}$. & Seres N., Simay G. \\
\hline 2006.12.21. & Pély, Gévai-puszta & 2 juv. & Zalai T. \\
\hline 2006.12.21. & Tata, Öreg-tó & 2 & Csonka P., Musicz L. \\
\hline 2006.12.22. & Naszály, Ferencmajori-halastavak & 3 & Csonka P. \\
\hline 2006.12.22. & Pély, Gévai-puszta & 1 juv. & Borbáth P. \\
\hline 2006.12.22. & Sarud, Panyita & 3 & Zalai T. \\
\hline 2006.12.23. & Tata, Öreg-tó & 2 & Musicz L., Hegyi Z. \\
\hline 2006.12.23. & Tiszavasvári, Fehér-szik & 1 & Simon Gy. \\
\hline 2006.12.25. & Tata, Öreg-tó & 2 & Riezing N. \\
\hline 2006.12.26. & Sarud, Tisza-tó (Sarudi-medence) & 5 & Zalai T. \\
\hline 2006.12.27. & Balmazújváros, Virágoskúti-halastó & 3 & Borza S., Kecskés J., Nagy L. \\
\hline 2006.12.27. & Geszt, Begécsi-víztároló & 5 ad. +1 juv. & Seres N., Kiss Á., Pabar Z., Monoki Á. \\
\hline 2006.12.27. & Kömlö, Büdös-kút-dülő & 8 & Zalai T. \\
\hline 2006.12.27. & Nagyhegyes, Elepi-halastó & 3 & Seprényi A. \\
\hline 2006.12.27. & Tarnaszentmiklós, Türügy-hát & 2 juv. & Borbáth P. \\
\hline 2006.12.29. & Tarnaszentmiklós, Türügy-hát & 6 & Zalai T., Borbáth P. \\
\hline 2006.12.30-31. & Debrecen, Ondód & 2 & Seprényi A.; Emri T., Zöld B. \\
\hline 2006.12.31. & Balmazújváros, 33-as út mellett & 1 & Emri T., Zöld B. \\
\hline 2007.01.01. & Geszt, Begécsi-víztároló & 5 & Vasas A., Molnár Sz., Mazula A. \\
\hline 2007.01.01. & Hajdúszoboszló, Ebes & 3 & Seprényi A. \\
\hline 2007.01.01. & Ópusztaszer, Csaj-hát & 2 ad. +2 juv. & Nagy T. \\
\hline 2007.01 .02 & Ópusztaszer, Csaj-hát & $1 \mathrm{ad}$ & Nagy T. \\
\hline 2007.01.02. & Tarnaszentmiklós, Türügy-hát & 5 & Borbáth P. \\
\hline 2007.01.03. & Abádszalók, Tisza-tó (Abádszalóki-öböl) & 2 & Zalai $\mathrm{T}$. \\
\hline 2007.01.03. & Tarnaszentmiklós, Nagy-fenék & 7 & Borbáth P., Zalai T. \\
\hline 2007.01 .04 . & Pusztaszer, Büdös-szék & 2 & Nagy T. \\
\hline 2007.01.06. & Balmazújváros, Kadarcs & 1 & Emri T., Zöld B. \\
\hline 2007.01.06. & Geszt, Begécsi-víztároló & 1 & Molnár Sz., Seres N., Vasas A. \\
\hline 2007.01.06. & Kardoskút, Fehér-tó & 2 & Kovács Á., Ampovics Zs. \\
\hline 2007.01 .06 & Nyékládháza, bányatavak & 1 & Simay A., Simay G., Simay A. \\
\hline 2007.01 .08 & Geszt, Begécsi-víztároló & $5 \mathrm{ad}$. & Seres N. \\
\hline 2007.01.08. & Jászkisér, Pusztakürt & 2 & Zalai T. \\
\hline 2007.01.08. & Pusztaszer, Büdös-széki-puszta & 3 & Nagy T. \\
\hline 2007.01.08. & Tetétlen & 2 & Simay G. \\
\hline 2007.01.09. & Fertőújlak, Borsodi-dűlö & $2 \mathrm{ad}$. & Pellinger A. \\
\hline 2007.01.09. & Nyergesújfalu, Duna (Nyerges-sziget) & 3 & Csonka P. \\
\hline 2007.01.09. & Pusztaszer, Büdös-szék & 1 ad. +2 juv. & Nagy T. \\
\hline 2007.01.09. & Sarud, Panyita & 2 ad. & Zalai $\mathrm{T}$. \\
\hline 2007.01.10. & Sarud, Panyita & 3 & Borbáth P. \\
\hline 2007.01.10-11. & Fertő́ujlak, Borsodi-dűlő & $1 \mathrm{ad}$. & Pellinger A.; Pellinger A., Szolnyik Cs. \\
\hline 2007.01.13. & Biharugra, Biharugrai-halastavak & 2 ad. & Seres N. \\
\hline 2007.01.13. & Makó, Bogárzó & 5 & Mészáros Cs. \\
\hline 2007.01.13. & Sarród & 3 & Pellinger A. \\
\hline 2007.01.13. & Szabadszállás & 1 & Kókay B. \\
\hline 2007.01 .14 & Hortobágy, Kun György-tó & 1 juv. & Simay A., Simay G. \\
\hline 2007.01.15. & Geszt, Begécsi-víztároló & 15 & Seres N. \\
\hline
\end{tabular}




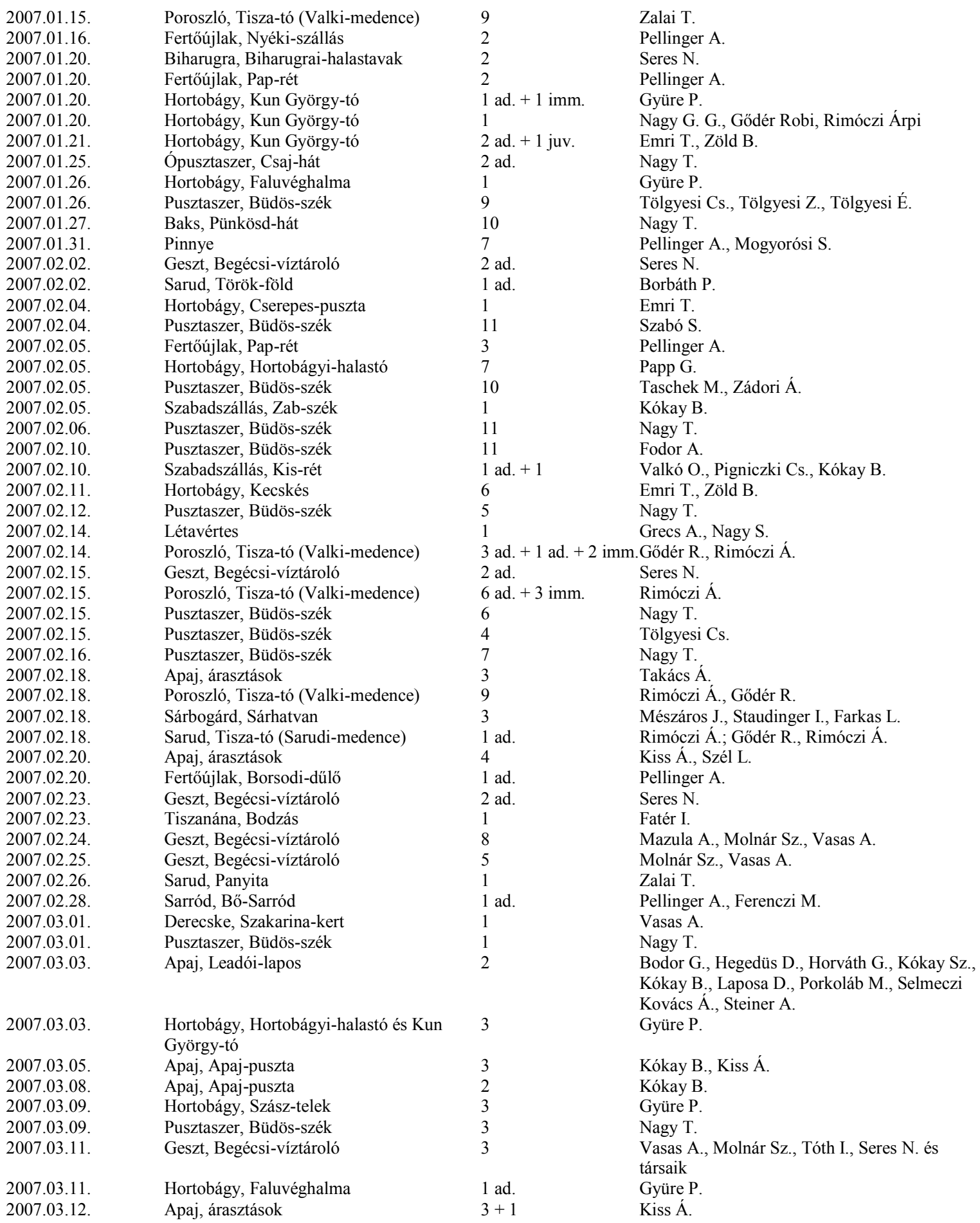

\subsection{Nílusi lúd (Alopochen aegyptiacus)}

A szezon során volt egy 2006 nyaráról származó adata (Pusztaszer, Büdös-szék), amelyet a Nomenclator Bizottság $\mathrm{D}_{\mathrm{E}}$ kategóriába fogadott el, azaz a madár eredete bizonytalan, de nagyobb valószínűséggel inkább fogságból szökött egyedről lehetett szó (ez a példány már 2006 tavaszán is azon a területen tartózkodott). Augusztus végi és öszi adatait a Nomenclator Bizottság $\mathrm{C}$ kategóriába fogadta el, azaz ezek a madarak vélhetően az Európában vadon költő populációból származhattak.

\footnotetext{
2006.07.21. 2006.08.26-30.

1 ad. $\left(D_{E}\right)$

$1 \mathrm{ad} .(\mathrm{C})$
}

Nagy T.

Borza S., Kecskés J., Nagy L., Szilágyi A., Vasas A. és mások; Horváth G., Kóta A., Selmeczi Kovács Á. 


$\begin{array}{llll}2006.09 .09 . & \text { Csenger, Szamos } & 1 \text { ad. (C) } & \text { Nagy M. } \\ 2006.09 .23 . & \text { Geszt, Begécsi-víztároló } & 1 \text { ad. (C) } & \text { Vasas A. } \\ 2006.10 .22 . & \text { Geszt, Begécsi-víztároló } & 1 \text { ad. (C) } & \text { Simay G., Vasas A. } \\ 2006.10 .30 . & \text { Geszt, Begécsi-víztároló } & 1 \text { ad. (C) } & \text { Seres N. } \\ 2006.11 .05 . & \text { Geszt, Begécsi-víztároló } & 1 \text { ad. (C) } & \text { Molnár Sz., Vasas A. }\end{array}$

\subsection{Vörös ásólúd (Tadorna ferruginea)}

A faj ritkasága miatt az adatokat hitelesítés céljából be kell nyújtani a Nomenclator Bizottságnak. Az itt közölt adatok közül a 2006 júliusában a szabadszállási Büdös-széken, a decemberben Rétszilason és Dióskál mellett, illetve a 2007 márciusának végén a Biharugrai-halastavon megfigyelt példányokat a Nomenclator Bizottság $\mathrm{D}_{\mathrm{A}}$ kategóriásnak minősítette (azaz eredetük ugyan kétgséges, de nagyobb a valószínüsége annak, hogy a madarak vadon élő populációból származhattak). A Hanságban és a Fertő térségében többször látott három madár (ad. tojó, ad. hím, imm. hím) esetében a madarak eredete ugyancsak bizonytalan, de ezekben az esetekben a Nomenclator Bizottság úgy ítélte meg, hogy e példányok inkább fogságból szökhettek, bár a vad eredet sem zárható ki teljes bizonyossággal ( $\mathrm{D}_{\mathrm{A}}$ kategória). A novembertől folymatosan a gersekaráti Olimpiai-tavon tartózkodó példány minden bizonnyal fogságból szökött lehetett (E kategória). Minden vörösásólúd-megfigyelésnél felmerül a madarak vad vagy fogsági eredetének a kérdése, ezért célszerü alaposan megfigyelni a madarak viselkedését és az esetlegesen rajtuk lévő jelölést, meret ezek támpontot nyújthatnak az eredet megítélésében.

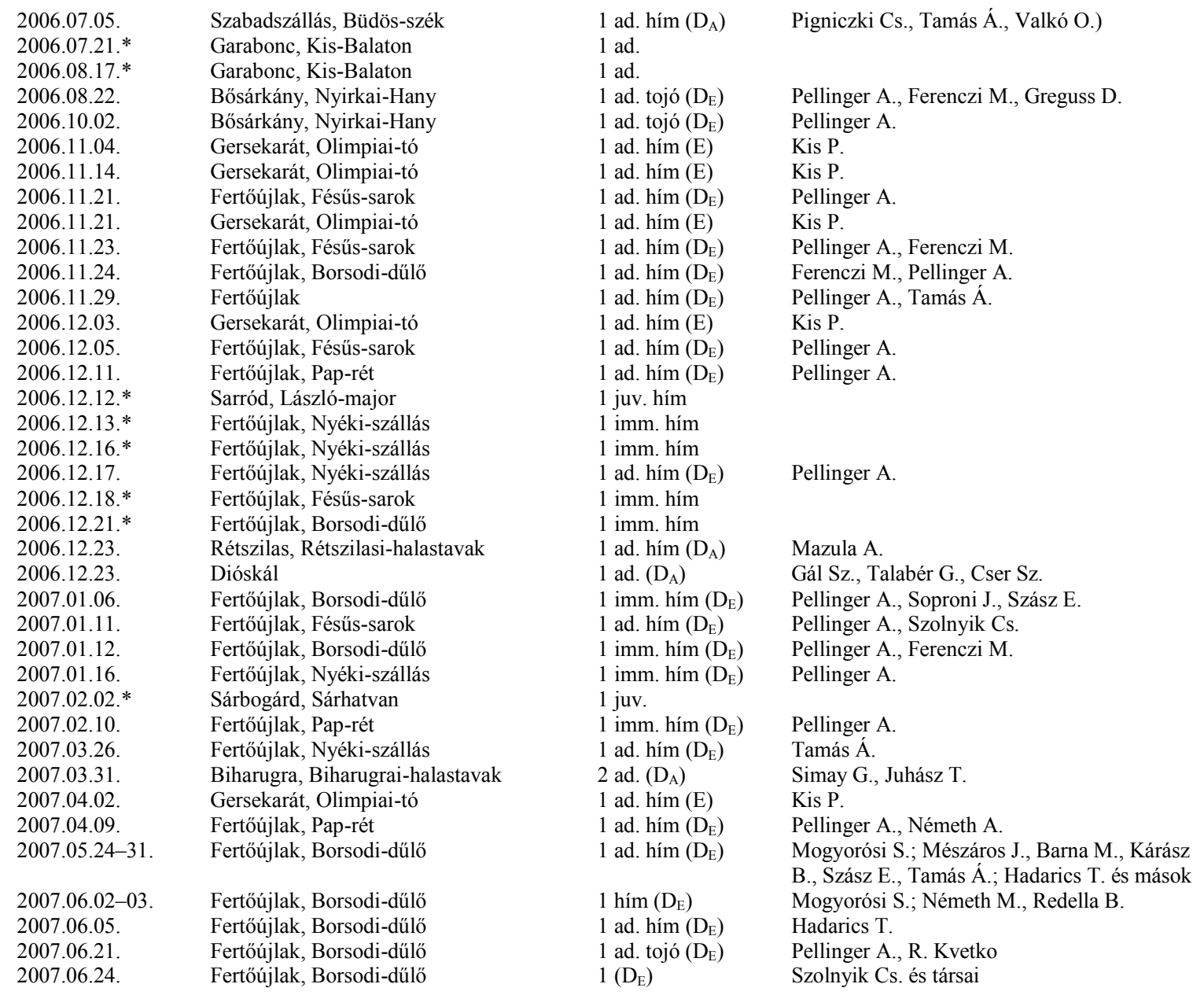

\subsection{Bütykös ásólúd (Tadorna tadorna)}

A bütykös ásólúd előfordulásai az utóbbi években gyakoribbakká váltak. A faj fészkelőként is megjelent hazánkban. Az egész szezon minden hónapjában voltak adatai, a 
téli időszakban kevesebb. Az őszi időszak legnagyobb létszámú csapatai (13 példány) szeptember közepén a dunatetétleni Böddi-széken, illetve november közepén a balmazújvárosi Virágoskúti-halastavon kerültek megfigyelésre. Tavasszal a legtöbbet (24 öreg példányt) Fertőújlakon látták április közepén. 2006-ban a Királyszentistván melletti szennyvíztónál két pár költött, egyik pár 12 fiókát nevelt, illetve e fiókás páron kívül egy másik fiókás pár is volt, de ott az öreg madarak egy idő után eltüntek és a fiókák szülők nélkül maradtak. Ezeken kívül a fertőújlaki Pap-réten is láttak egy tojót egyetlen fiókával június közepén, tehát a faj a Fertőnél is költött ebben az évben.

\begin{tabular}{|c|c|c|c|}
\hline 2006.07.01. & $\begin{array}{l}\text { Királyszentistván, Füzföi Szennyvíz Kft. } \\
\text { utótisztító tava }\end{array}$ & 1 pár +7 pull. & Szelle E. \\
\hline 2006.07 .03 & $\begin{array}{l}\text { Királyszentistván, Füzföi Szennyvíz Kft. } \\
\text { utótisztító tava }\end{array}$ & 1 pár +7 pull. & Szelle E. \\
\hline 2006.07.05. & $\begin{array}{l}\text { Királyszentistván, Füzföi Szennyvíz Kft. } \\
\text { utótisztító tava }\end{array}$ & 1 pár +7 pull. & Szelle E. \\
\hline 2006.07.06. & $\begin{array}{l}\text { Királyszentistván, Fűzföi Szennyvíz Kft. } \\
\text { utótisztító tava }\end{array}$ & 2 ad. & Szelle E. \\
\hline 2006.07 .06 & Szeged, Szegedi-Fertő & $1 \mathrm{ad}$ & Domján A. \\
\hline 2006.07 .07 & Fertőújlak, Borsodi-dülő & 1 ad. tojó & Hadarics $\mathrm{T}$. \\
\hline $2006.07 .07-08$ & $\begin{array}{l}\text { Királyszentistván, Füzföi Szennyvíz Kft. } \\
\text { utótisztító tava }\end{array}$ & 1 pár +7 pull. & Szelle E. \\
\hline 2006.07 .10 & Fertőújlak, Borsodi-dülő & 2 ad. & Hadarics T. \\
\hline 2006.07.11. & Fertőújlak, élőhely-rekonstrukció & 8 & Élö G. \\
\hline 2006.07.12. & Fertőújlak, Borsodi-dülő & 1 ad. tojó & Hadarics $\mathrm{T}$. \\
\hline 2006.07.12. & $\begin{array}{l}\text { Királyszentistván, Fűzföi Szennyvíz Kft. } \\
\text { utótisztító tava }\end{array}$ & 1 pár +7 pull. & Szelle E. \\
\hline 2006.07 .14 & Fertőújlak, Borsodi-dűlő & $1 \mathrm{ad}$ & Hadarics T. \\
\hline 2006.07 .14 & $\begin{array}{l}\text { Királyszentistván, Füzföi Szennyvíz Kft. } \\
\text { utótisztító tava }\end{array}$ & 1 pár +7 pull. & Szelle E. \\
\hline 2006.07 .15 & $\begin{array}{l}\text { Királyszentistván, Füzföi Szennyvíz Kft. } \\
\text { utótisztító tava }\end{array}$ & 2 ad. +7 juv. & Szelle E., Széplaki I. \\
\hline $2006.07 .18-19$ & $\begin{array}{l}\text { Királyszentistván, Fűzföi Szennyvíz Kft. } \\
\text { utótisztító tava }\end{array}$ & 2 ad. +7 juv. & Szelle E. \\
\hline 2006.07.20. & Fertőújlak, Borsodi-dülö & $\begin{array}{l}1 \text { ad. tojó }+8 \text { juv. }+1 \\
\text { ad. hím }\end{array}$ & Hadarics T. \\
\hline 2006.07 .21 & $\begin{array}{l}\text { Királyszentistván, Fűzföi Szennyvíz Kft. } \\
\text { utótisztító tava }\end{array}$ & 2 ad. +7 juv. & Szelle E. \\
\hline 2006.07 .23 & $\begin{array}{l}\text { Királyszentistván, Füzföi Szennyvíz Kft. } \\
\text { utótisztító tava }\end{array}$ & 2 ad. +7 juv. & Szelle E. \\
\hline $2006.07 .25-26$ & $\begin{array}{l}\text { Királyszentistván, Füzföi Szennyvíz Kft. } \\
\text { utótisztító tava }\end{array}$ & 1 ad. +7 juv. & Szelle E. \\
\hline 2006.07.29. & Dunatetétlen, Böddi-szék & 1 juv. & $\begin{array}{l}\text { Porkoláb M., Bodor G., Horváth G., Kókay B., } \\
\text { Jed M. }\end{array}$ \\
\hline 2006.08 .06 & Hortobágy, Fényesi-halastó & 3 juv. & $\begin{array}{l}\text { Kovács G., Bodor G., Horváth G., Jed M., } \\
\text { Kókay B., Selmeczi Kovács Á. }\end{array}$ \\
\hline 2006.08 .12 . & Nagyiván, Kis-Jusztus & 2 juv. & Kiss B. \\
\hline 2006.08 .17 & Fertőújlak, Borsodi-dülő & 1 ad. tojó & Tamás Á. \\
\hline 2006.08.24. & Fertőújlak, Borsodi-dülö & $1 \mathrm{ad}$ & Hadarics T. \\
\hline 2006.09.15-17. & Dunatetétlen, Böddi-szék & 13 & $\begin{array}{l}\text { Németh Á., Pigniczki Cs.; Bodor G., Horváth G.; } \\
\text { Pigniczki Cs., Nyúl M., Valkó O. }\end{array}$ \\
\hline 2006.09 .17 & Sárkeresztúr, Sárkány-tó & 1 ad. hím & Oláh S., Szalai K. \\
\hline 2006.10 .07 & Balatonőszöd, Balaton & 1 ad. tojó & Cser Sz., Faragó Á., Gál Sz. \\
\hline 2006.10 .08 & Geszt, Begécsi-víztároló & 1 & Durkó L., Seres N., Hegyesi A. \\
\hline 2006.10 .08 & Szeged, Fehér-tó & 1 juv. & Mészáros Cs. \\
\hline 2006.10 .20 & Balmazújváros, Virágoskúti-halastó & 12 & Varga L., Szondi L. \\
\hline 2006.10 .21 & Balatonőszöd, Balaton & 1 ad. & Cser Sz., Faragó Á., Gál Sz. \\
\hline 2006.10 .21 & Szeged, Szegedi-Fertő & 1 & Barócsi A. és társai \\
\hline 2006.10 .23 & Hortobágy, Hortobágyi-halastó & 12 & Oláh J., Simay A. \\
\hline 2006.10 .26 & Balmazújváros, Virágoskúti-halastó & 11 & Simay A., Simay G. \\
\hline 2006.10 .29 & Geszt, Begécsi-víztároló & $1 \mathrm{ad}$ & $\begin{array}{l}\text { Schmidt A., Seres N., Kazi R., Fézler G., } \\
\text { Megyery Á., Varga P., Potyó I. }\end{array}$ \\
\hline 2006.10 .31 & Balmazújváros, Virágoskúti-halastó & 12 & A. L., Nagy G. G. \\
\hline 2006.11 .02 & Dinnyés, Dinnyési-halastavak & 3 & Szél L. \\
\hline 2006.11.05. & Geszt, Begécsi-víztároló & 1 & Molnár Sz., Vasas A. \\
\hline 2006.11.07-08. & Dinnyés, Dinnyési-Fertő & 3 & Pánya Cs.; Kiss Á., Szél L. \\
\hline 2006.11.11. & Balmazújváros, Virágoskúti-halastó & 12 & Varga L., Varga L. \\
\hline 2006.11 .12 & Dinnyés, Dinnyési-Fertő & 1 & Vasuta G. \\
\hline 2006.11 .18 & Balmazújváros, Virágoskúti-halastó & 13 & Simay A., Zalai T. \\
\hline 2006.11 .18 & Békés, halastavak & 1 ad. tojó & Durkó L. \\
\hline 2006.11 .19 & Tömörkény, Csaj-tó & $1 \mathrm{ad}$ & Bede Á., Öze P. \\
\hline 2006.11.20. & Rétszilas, Rétszilasi-halastavak & 3 & \\
\hline 2006.11 .25 & Balmazújváros, Virágoskúti-halastó & 5 & Tar J., Katona J., Kecskés J., Borza S. \\
\hline
\end{tabular}




\begin{tabular}{|c|c|c|c|}
\hline 2006.12 .01 & Szabadbattyán, halastó & 1 & Szimuly Gy. \\
\hline 2006.12 .03 . & Balmazújváros, Virágoskúti-halastó & 2 & Weszelinov O., Koczka A. \\
\hline 2006.12 .17 & Rétszilas, Rétszilasi-halastavak & 1 & $\begin{array}{l}\text { Mészáros J., Staudinger I., Nagy I., Hajdú T., } \\
\text { Cserna Z. }\end{array}$ \\
\hline 2006.12 .17 & Szeged, Fehér-tó & 11 & Kókai K. \\
\hline 2006.12 .22 & Tömörkény, Csaj-tó & 2 & Domján A.; Nagy T. \\
\hline 2006.12 .28 & Köröstarcsa, Gácsháti-halastó & 2 & Nyíri L., Nyíri B. \\
\hline 2006.12.29. & Szeged, Fehér-tó & 4 & Lázár B., Bérdi G., Gyarmati G. \\
\hline 2006.12 .30 & Szeged, Fehér-tó & 1 & Mészáros Cs., Engi L. \\
\hline 2006.12 .30 & Szeged, Szegedi-Fertő & 1 & Mészáros Cs., Engi L. \\
\hline 2006.12.31. & Budapest, Duna (Óbudai-sziget) & 1 ad. tojó & Szegedy I. \\
\hline $2007.01 .02-03$. & Budapest, Duna (Óbudai-sziget) & 1 ad. tojó & Lendvai Cs., Fodor A.; Szalai K.; Bajor Z. \\
\hline 2007.01.04. & Pusztaszer, Büdös-szék & 1 & Nagy T. \\
\hline 2007.01.05. & Szeged, Fehér-tó & 1 & Mészáros Cs., Engi L. \\
\hline 2007.01.05-06. & Fertőújlak, Borsodi-dülö & 3 & Pellinger A.; Pellinger A., Soproni J., Szász E. \\
\hline 2007.01.07. & Sumony, Sumonyi-halastó & 1 & Lengyel A. \\
\hline 2007.01.08. & Szeged, Fehér-tó & 1 tojó & Kókai K. \\
\hline 2007.01.09. & Fertőújlak, Borsodi-dülő & 3 & Pellinger A. \\
\hline 2007.01.11-12. & Fertőújlak, Borsodi-dülö & 6 & $\begin{array}{l}\text { Pellinger A., Szolnyik Cs.; Pellinger A., Ferenczi } \\
\text { M. }\end{array}$ \\
\hline 2007.01 .13 . & Szeged, Fehér-tó & 1 & Ampovics Zs., Domján A. \\
\hline 2007.01 .14 & Fertőújlak, Borsodi-dülő & 6 & Pellinger A. \\
\hline 2007.01 .14 & Tömörkény, Csaj-tó & 3 & Tóth S., Hajas G.; Domján A. \\
\hline 2007.01 .20 & $\begin{array}{l}\text { Királyszentistván, Füzföi Szennyvíz Kft. } \\
\text { utótisztító tava }\end{array}$ & 3 & Szelle E. \\
\hline 2007.01 .24 & Apaj, Ürbői-halastavak & 1 juv. & Németh F. \\
\hline 2007.01 .31 & Fertőújlak, Borsodi-dülő & 6 & Pellinger A. \\
\hline 2007.02 .02 & Fertőújlak, Borsodi-dülő & 5 & R. Kvetko \\
\hline 2007.02 .04 & Szeged, Fehér-tó & 4 & Ampovics Zs.; Kókai K. \\
\hline 2007.02 .06 & Fertőújlak, Borsodi-dülö & 1 & Hadarics T. \\
\hline 2007.02.09. & Fertőújlak, Borsodi-dülő & 5 ad. & Pellinger A., Tamás Á. \\
\hline 2007.02 .10 & Szeged, Fehér-tó & 3 & Torday L., Tóth Bálint, Göblyös D., Bánfi A. \\
\hline 2007.02.11. & Dunatetétlen, Böddi-szék & $1 \mathrm{ad}$ & Berényi Zs., Pintér K., Pintér B., Verseczki N. \\
\hline 2007.02 .11 & Fertőújlak, Borsodi-dülö & 5 ad. hím +1 ad. tojó & László Cs., Tamás Á. \\
\hline 2007.02 .18 & Szeged, Fehér-tó & 8 & Kiss O., Tokody B. \\
\hline 2007.02 .18 & Tömörkény, Csaj-tó & 3 & Domján A. \\
\hline 2007.02 .19 & Fertőújlak, Borsodi-dülő & 8 ad. & Pellinger A., Tamás Á. \\
\hline 2007.02.20 & Tömörkény, Csaj-tó & 3 & Nagy T. \\
\hline 2007.02 .23 & $\begin{array}{l}\text { Királyszentistván, Füzföi Szennyvíz Kft. } \\
\text { utótisztító tava }\end{array}$ & 1 hím & Szelle E. \\
\hline 2007.02.23. & Nagykanizsa, Miklósfai-halastavak & 2 & Faragó Á., Gál Sz. \\
\hline $2007.02 .24-25$. & Fertőújlak, Borsodi-dülő & 5 ad. & $\begin{array}{l}\text { Kovács Gy.; Szász E., Kárász B., Benei Zs., L. } \\
\text { Cs., Tamás Á. }\end{array}$ \\
\hline 2007.02.27. & Szeged, Fehér-tó & 1 & Kókai K. \\
\hline 2007.03.01. & Fertőújlak, Nyéki-szállás & 2 & Agócs P., Tamás Á. \\
\hline 2007.03 .01 & Szeged, Fehér-tó & 10 & Tölgyesi Cs. \\
\hline 2007.03.03. & Dinnyés, halastó & 1 & Mészáros J., Takács Á. \\
\hline 2007.03 .03 & $\begin{array}{l}\text { Királyszentistván, Füzföi Szennyvíz Kft. } \\
\text { utótisztító tava }\end{array}$ & 1 ad. hím & Szelle E. \\
\hline 2007.03 .06 & Szeged, Fehér-tó & 6 & Tölgyesi Cs. \\
\hline 2007.03.08. & Apaj, Szúnyog-puszta & 4 & Pánya Cs., Kókay B. \\
\hline 2007.03 .09 & Fertőújlak, Borsodi-dülő & 3 ad. & Tamás Á. \\
\hline 2007.03 .11 & Dunatetétlen, Böddi-szék & 1 ad. & Kiss Á., Kardos É. \\
\hline 2007.03 .11 & Mikepércs, Tócó-Kösely menti víztároló & 1 pár & Pásti Cs. \\
\hline 2007.03 .13 & Apaj, Alsó-Szúnyog & 1 & Kókay B. \\
\hline 2007.03 .14 & Mikepércs, Tócó-Kösely menti víztároló & 2 pár & Balázsi P., Hoffer Á., Gilányi G. \\
\hline 2007.03 .15 & Apaj, Ürbői-halastavak & 1 ad. hím & Laposa D., Kókay B., Lendvai Cs. \\
\hline 2007.03 .15 & Dunatetétlen, Böddi-szék & 2 & Kiss Á., Kardos É. \\
\hline 2007.03 .15 & Harkakötöny, halastavak & 15 & Ternyák J. \\
\hline 2007.03 .16 & Mikepércs, Tócó-Kösely menti víztároló & 2 pár & Tar A., Papp G \\
\hline 2007.03 .17 & Soponya, Soponyai-halastavak & 1 & Mészáros J., Staudinger I. \\
\hline 2007.03 .18 & Hortobágy, Hortobágyi-halastó & 1 & Balla D. \\
\hline 2007.03 .18 & Szeged, Szegedi-Fertő & 8 & Tokody B. \\
\hline 2007.03.24. & Fertőújlak, Borsodi-dülö & 5 & Tóth V., Sporcsics D., Nagy Á., László Cs. \\
\hline 2007.03.25. & Dunatetétlen, Böddi-szék & 7 & Bodor G., Hegedüs D., Horváth G., Laposa D. \\
\hline 2007.03 .25 & Harkakötöny, halastavak & 1 ad. tojó & Kiss T. \\
\hline 2007.03 .25 & Szeged, Szegedi-Fertő & 2 & Kókai K. \\
\hline 2007.03 .29 & Szeged, Szegedi-Fertő & 3 & Tóth B., Göblyös D. \\
\hline 2007.03.30. & Fertőújlak, Borsodi-dülő & 9 ad. & Tamás Á., Hadarics T., Pellinger A. \\
\hline $2007.03 .30-31$. & $\begin{array}{l}\text { Királyszentistván, Füzföi Szennyvíz Kft. } \\
\text { utótisztító tava }\end{array}$ & 1 pár & Szelle E. \\
\hline 2007.03 .31 & Mikepércs, Tócó-Kösely menti víztároló & 1 pár & Vass B. \\
\hline 2007.04 .01 & Fertőújlak, Borsodi-dülő & 3 ad. & Hadarics T. \\
\hline 2007.04 .01 & Hortobágy, Fényesi-halastó & 3 & Pánya Cs. \\
\hline 2007.04 .01 & Királyszentistván, Füzföi Szennyvíz Kft. & 1 pár & Szelle E. \\
\hline
\end{tabular}




\begin{tabular}{|c|c|c|c|}
\hline 2007.04 .01 & Mikepércs, Tócó-Kösely menti víztároló & 1 pár & Pásti Cs. \\
\hline 2007.04 .01 & Szeged, Fehér-tó & 1 & Kókai K. \\
\hline 2007.04 .03 & $\begin{array}{l}\text { Királyszentistván, Füzföi Szennyvíz Kft. } \\
\text { utótisztító tava }\end{array}$ & 1 pár & Szelle E. \\
\hline $2007.04 .05-06$. & Dunatetétlen, Böddi-szék & 2 & Tölgyesi Cs., Tölgyesi Z. \\
\hline $2007.04 .05-06$. & $\begin{array}{l}\text { Királyszentistván, Füzföi Szennyvíz Kft. } \\
\text { utótisztító tava }\end{array}$ & 1 pár & Szelle E. \\
\hline 2007.04 .06 . & Hortobágy, Fényesi-halastó & 1 pár & Kovács G., Kovács G. K. \\
\hline 2007.04 .08 & Fertőújlak, Nyéki-szállás & 11 & Pellinger A., Ferenczi M., Kraft Gy. \\
\hline 2007.04 .08 & Rétszilas, Rétszilasi-halastavak & 1 ad. hím & Vasuta G. \\
\hline 2007.04 .09 . & Kardoskút, Fehér-tó & 3 & Kiss O., Tokody B. \\
\hline 2007.04.09. & Orosháza, Kis-Sóstó & 3 ad. & Szőke P. \\
\hline 2007.04.09-10. & $\begin{array}{l}\text { Királyszentistván, Füzföi Szennyvíz Kft. } \\
\text { utótisztító tava }\end{array}$ & 1 pár & Szelle E. \\
\hline 2007.04.12. & Fertőújlak, Nyéki-szállás & 6 ad. & Hadarics T. \\
\hline 2007.04.12-14. & $\begin{array}{l}\text { Királyszentistván, Füzföi Szennyvíz Kft. } \\
\text { utótisztító tava }\end{array}$ & 1 pár & Szelle E. \\
\hline 2007.04 .14 & Apaj, árasztások & 2 & Takács Á. \\
\hline 2007.04 .14 . & Fertőújlak, Nyéki-szállás & 17 & Mogyorósi S. \\
\hline 2007.04 .15 . & Dunatetétlen, Böddi-szék & 7 & $\begin{array}{l}\text { Fodor A., Lendvai Cs., D. Bastaja, Szücs Cs., } \\
\text { Steiner A. }\end{array}$ \\
\hline 2007.04 .15 & Mikepércs, sertéstrágya-szikkasztó & 1 pár & Pásti Cs. \\
\hline 2007.04 .15 . & Rétszilas, Rétszilasi-halastavak & 1 & Mészáros J., Staudinger I., Farkas L. \\
\hline 2007.04 .15 . & Sumony, Sumonyi-halastó & 1 & Ónodi M., Pinczehelyi J. \\
\hline 2007.04 .15 & Szeged, Szegedi-Fertő & 3 & Kókai K. \\
\hline 2007.04 .16 & Fertőújlak, Nyéki-szállás & 24 ad. & Pellinger A., Tamás Á. \\
\hline 2007.04 .16 . & Sumony, Sumonyi-halastó & 1 tojó & Krukenberger T., Gregorits J. \\
\hline $2007.04 .16-17$. & $\begin{array}{l}\text { Királyszentistván, Füzföi Szennyvíz Kft. } \\
\text { utótisztító tava }\end{array}$ & 1 pár & Szelle E. \\
\hline 2007.04 .17 & Szeged, Szegedi-Fertő & 9 & Tölgyesi Cs. \\
\hline 2007.04 .18 & Hortobágy, Hortobágyi-halastó & 1 ad. tojó & Balázsi P. \\
\hline 2007.04 .18 & $\begin{array}{l}\text { Királyszentistván, Füzföi Szennyvíz Kft. } \\
\text { utótisztító tava }\end{array}$ & 2 pár & Szelle E. \\
\hline 2007.04.19. & $\begin{array}{l}\text { Királyszentistván, Füzföi Szennyvíz Kft. } \\
\text { utótisztító tava }\end{array}$ & 1 pár + 1 hím & Szelle E. \\
\hline 2007.04 .20 & Dunatetétlen, Böddi-szék & 1 ad. hím +2 ad. tojó & Kókay B. \\
\hline 2007.04 .20 & $\begin{array}{l}\text { Királyszentistván, Füzföi Szennyvíz Kft. } \\
\text { utótisztító tava }\end{array}$ & 2 & Szelle E. \\
\hline 2007.04.21. & Naszály, Ferencmajori-halastavak & 4 & Szimuly Gy., Szimuly Sz. \\
\hline 2007.04.21-23. & $\begin{array}{l}\text { Királyszentistván, Füzföi Szennyvíz Kft. } \\
\text { utótisztító tava }\end{array}$ & 2 pár & Szelle E. \\
\hline 2007.04 .22 & Apaj, Ürbői-halastavak & 2 & Fodor A. \\
\hline 2007.04 .22 & Naszály, Ferencmajori-halastavak & 1 & Szimuly Gy., Szimuly Sz. \\
\hline 2007.04 .23 & Apaj, árasztások & 3 & Novák G. \\
\hline 2007.04 .24 & Fertőújlak, Nyéki-szállás & 2 ad. & Hadarics T. \\
\hline 2007.04 .24 & Naszály, Ferencmajori-halastavak & $1 \mathrm{imm}$. & Szimuly Gy., Csonka P. \\
\hline 2007.04 .24 & Sárkeresztúr, Sárkány-tó & 4 & Kiss Á. \\
\hline 2007.04 .25 & $\begin{array}{l}\text { Királyszentistván, Füzfői Szennyvíz Kft. } \\
\text { utótisztító tava }\end{array}$ & 2 pár & Szelle E. \\
\hline 2007.04 .25 & Naszály, Ferencmajori-halastavak & 2 & Riezing N.; Szimuly Gy., Szimuly Sz. \\
\hline 2007.04 .26 . & Fertőújlak, Nyéki-szállás & $4 \mathrm{ad}$ & Hadarics T. \\
\hline 2007.04 .27 & Sárkeresztúr, Sárkány-tó & 2 ad. hím +4 ad. tojó & Oláh S., Szalai K. \\
\hline 2007.04 .28 & Dinnyés, Dinnyési-Fertő & 4 & Árvai G., Bruckner A. és társaik \\
\hline 2007.04 .28 & $\begin{array}{l}\text { Királyszentistván, Fűzföi Szennyvíz Kft. } \\
\text { utótisztító tava }\end{array}$ & 1 pár + 1 hím & Szelle E. \\
\hline 2007.04 .28 & Szeged, Szegedi-Fertő & 3 & Domján A. \\
\hline 2007.04 .29 & Sárkeresztúr, Sárkány-tó & 3 ad. & Oláh S., Szalai K. \\
\hline 2007.04 .30 & Apaj, Szúnyog-puszta & 2 & Pintér B., Verseczki N. \\
\hline 2007.04 .30 & Geszt, Begécsi-víztároló & 5 & Viczián K., Klenk V., Mazula A. \\
\hline 2007.04 .30 & $\begin{array}{l}\text { Királyszentistván, Füzföi Szennyvíz Kft. } \\
\text { utótisztító tava }\end{array}$ & 1 pár + 1 hím & Szelle E. \\
\hline 2007.05 .01 & Hortobágy, Hortobágyi-halastó & $5+2$ & Nagy M. \\
\hline 2007.05 .01 & Rétszilas, Rétszilasi-halastavak & 1 & Kiss Á., Kardos É., Kiss J. \\
\hline 2007.05 .02 & $\begin{array}{l}\text { Királyszentistván, Füzföi Szennyvíz Kft. } \\
\text { utótisztító tava }\end{array}$ & 3 & Szelle E. \\
\hline 2007.05 .03 & Fertőújlak, Borsodi-dűlő & 2 ad. & Hadarics T. \\
\hline 2007.05 .03 . & Fertőújlak, Nyéki-szállás & 2 ad. & Hadarics T. \\
\hline 2007.05.04. & $\begin{array}{l}\text { Királyszentistván, Füzfői Szennyvíz Kft. } \\
\text { utótisztító tava }\end{array}$ & 2 pár & Szelle E. \\
\hline 2007.05.04. & Nyíregyháza, Nagy-Vadas-tó & 1 & Gilányi G., Török H. A. \\
\hline $2007.05 .04-05$. & Apaj, árasztások & 2 & Szél L., Kiss Á.; Bodor G., Katona I., Vámosi K. \\
\hline 2007.05 .05 & $\begin{array}{l}\text { Királyszentistván, Füzfooi Szennyvíz Kft. } \\
\text { utótisztító tava }\end{array}$ & 2 pár & Szelle E. \\
\hline 2007.05 .06 . & Apaj, árasztások & 1 & Mészáros J., Barna M., Takács Á. \\
\hline 2007.05.06. & Fertőújlak, Nyéki-szállás & 5 & Németh M., Redella B. \\
\hline 2007.05 .06 & Szeged, Szegedi-Fertő & 3 & Mészáros Cs., Engi L. \\
\hline
\end{tabular}




\begin{tabular}{|c|c|c|c|}
\hline 2007.05.07. & Fertőújlak, Borsodi-dülö & 6 ad. & Hadarics T. \\
\hline 2007.05.07. & Hortobágy, Hortobágyi-halastó & 3 & Kóta A. és társai \\
\hline 2007.05.10. & Apaj, árasztások & 3 & Vasuta G., Kocsis K. \\
\hline $2007.05 .10-11$. & $\begin{array}{l}\text { Királyszentistván, Füzfői Szennyvíz Kft. } \\
\text { utótisztító tava }\end{array}$ & 1 ad. hím & Szelle E. \\
\hline 2007.05.11. & Fertőújlak, Borsodi-dűlő & 11 & Pellinger A. \\
\hline 2007.05.12. & Apaj, árasztások & 5 ad. & $\begin{array}{l}\text { Verseczki N., Pintér B., Szabó Z., Ungi B., } \\
\text { Horváth G., Kóta A., Selmeczi Kovács Á., Bajor } \\
\text { Z., Bodor G., Hegedüs D., Steiner A. }\end{array}$ \\
\hline 2007.05.12. & Geszt, Begécsi-víztároló & 6 & Molnár Sz., Vasas A., Mazula A. \\
\hline 2007.05.12. & $\begin{array}{l}\text { Királyszentistván, Füzföi Szennyvíz Kft. } \\
\text { utótisztító tava }\end{array}$ & 1 pár + 1 hím & Szelle E. \\
\hline 2007.05.12-13. & Ajka, zagytározó & 2 ad. & Bruckner A.; Busa Á. \\
\hline 2007.05.13. & Szeged, Fehér-tó & 2 & Domján A. \\
\hline 2007.05.14. & Fertőújlak, Nyéki-szállás & 8 & Vasuta G., Kocsis K. \\
\hline 2007.05.14. & Kaba, cukorgyári ülepítők & 2 ad. & Nagy G. G., Simay A. \\
\hline 2007.05.14. & Naszály, Ferencmajori-halastavak & 1 ad. & Szimuly Gy. \\
\hline 2007.05.14. & Szeged, Fehér-tó & 1 & Kiss O., Tokody B. \\
\hline $2007.05 .14-17$ & $\begin{array}{l}\text { Királyszentistván, Füzföi Szennyvíz Kft. } \\
\text { utótisztító tava }\end{array}$ & $3 \mathrm{ad}$. & Szelle E. \\
\hline 2007.05 .15 . & Fertőújlak, Borsodi-dülő & 8 ad. & Hadarics T. \\
\hline 2007.05.15. & Fertőújlak, Nyéki-szállás & $3 \mathrm{ad}$. & Hadarics $\mathrm{T}$. \\
\hline 2007.05.16. & Fertőújlak, Borsodi-dủlő & 18 & Pellinger A. \\
\hline 2007.05.16. & Naszály, Ferencmajori-halastavak & 1 ad. hím & Szimuly Sz., Szimuly D., Szimuly Gy. \\
\hline 2007.05.17. & Pusztaszer, Büdös-szék & 10 & Tölgyesi Cs. \\
\hline 2007.05.18. & Apaj, árasztások & 2 ad. & Budavári L., Losonci E. \\
\hline 2007.05.18. & Dinnyés, Dinnyési-Fertő & 1 & Kicsid A., Hegedüs D. \\
\hline 2007.05.18. & Geszt, Begécsi-víztároló & 2 & Gál Z., Durkó L., Boldog G., Balázs P. \\
\hline 2007.05.19. & Dunatetétlen, Böddi-szék & 10 & Kiss Á., Kardos É. \\
\hline 2007.05.19. & Fertőújlak, Borsodi-dűlő & $14 \mathrm{ad}$. & Hadarics T. \\
\hline 2007.05.19. & $\begin{array}{l}\text { Királyszentistván, Füzföi Szennyvíz Kft. } \\
\text { utótisztító tava }\end{array}$ & 2 pár & Szelle E. \\
\hline 2007.05.20. & Apaj, Alsó-Szúnyog & 2 ad. & Hegedüs D., Lendvai Cs. \\
\hline 2007.05.20 & Debrecen, Lovász-zugi-tavak & 1 & Pásti Cs. \\
\hline 2007.05.21. & Fertő́úlak, Borsodi-dủlő & $13 \mathrm{ad}$. & Hadarics T. \\
\hline 2007.05.22. & $\begin{array}{l}\text { Királyszentistván, Füzföi Szennyvíz Kft. } \\
\text { utótisztító tava }\end{array}$ & $3 \mathrm{ad}$. & Szelle E. \\
\hline 2007.05.24. & Fertőújlak, Borsodi-dűlő & 11 & Mogyorósi S. \\
\hline 2007.05.24. & $\begin{array}{l}\text { Királyszentistván, Füzföi Szennyvíz Kft. } \\
\text { utótisztító tava }\end{array}$ & $\begin{array}{l}1 \text { pár }+12 \text { pull. + } 1 \\
\text { pár }\end{array}$ & Szelle E. \\
\hline 2007.05.25. & Ajka, zagytározó & $2 \mathrm{ad}$ & Busa Á. \\
\hline 2007.05.26. & Fertőújlak, Borsodi-dűlő & 6 & Kiss Á., Kardos É., Kiss J. \\
\hline 2007.05.26. & $\begin{array}{l}\text { Királyszentistván, Füzföi Szennyvíz Kft. } \\
\text { utótisztító tava }\end{array}$ & 3 pár +11 pull. & Szelle E. \\
\hline 2007.05.26. & Szeged, Fehér-tó & 1 & Domján A. \\
\hline 2007.05.27. & Apaj, Alsó-Szúnyog & 2 & Fodor A., Lendvai Cs. \\
\hline 2007.05.28. & Fertő́ulak, Borsodi-dűlő & 11 & Németh M., Redella B. \\
\hline 2007.05.28. & $\begin{array}{l}\text { Királyszentistván, Füzfői Szennyvíz Kft. } \\
\text { utótisztító tava }\end{array}$ & 3 pár + 11 pull. & Szelle E. \\
\hline 2007.05.28. & Szeged, Fehér-tó & 9 & Domján A. \\
\hline 2007.05.29. & Fertőújlak, Borsodi-dűlő & 3 ad. & Hadarics $\mathrm{T}$. \\
\hline 2007.05.30. & $\begin{array}{l}\text { Királyszentistván, Füzföi Szennyvíz Kft. } \\
\text { utótisztító tava }\end{array}$ & 3 pár +11 pull. & Szelle E. \\
\hline 2007.05.30. & Szeged, Fehér-tó & 11 & Domján A. \\
\hline 2007.05.31. & Fertőújlak, Borsodi-dűlő és Pap-rét & $12 \mathrm{ad}$. & $\begin{array}{l}\text { Pellinger A., Pálinkás A., Illés G., László Cs., } \\
\text { Tamás Á. }\end{array}$ \\
\hline 2007.05.31. & Szeged, Fehér-tó & 5 & Mészáros Cs. \\
\hline 2007.06.01. & Sárkeresztúr, Sárkány-tó & 2 & Szél L., Kiss Á. \\
\hline 2007.06.01. & Szeged, Szegedi-Fertő & 1 & Szücs P. \\
\hline 2007.06.02. & $\begin{array}{l}\text { Királyszentistván, Füzföi Szennyvíz Kft. } \\
\text { utótisztító tava }\end{array}$ & 2 pár +11 pull. & Szelle E. \\
\hline 2007.06 .02 . & Szeged, Fehér-tó & 5 & Domján A. \\
\hline 2007.06.03. & Fertőújlak, Borsodi-dűlő & 2 & Németh M., Redella B. \\
\hline 2007.06.03. & Szabadszállás & 9 & Krukenberger $\mathrm{T}$. \\
\hline 2007.06.03. & Szeged, Szegedi-Fertő & 4 & Szücs P. \\
\hline 2007.06.05. & $\begin{array}{l}\text { Királyszentistván, Füzföi Szennyvíz Kft. } \\
\text { utótisztító tava }\end{array}$ & 2 pár +9 pull. & Szelle E. \\
\hline 2007.06.09. & Dunatetétlen, Böddi-szék & 5 & Tölgyesi Z., Tölgyesi Cs. \\
\hline 2007.06.09. & Fertőújlak, Nyéki-szállás & $3 \mathrm{ad}$ & Szász E., Kárász B., Tamás Á. \\
\hline 2007.06.09. & $\begin{array}{l}\text { Királyszentistván, Füzfői Szennyvíz Kft. } \\
\text { utótisztító tava }\end{array}$ & $\begin{array}{l}2 \text { pár }+9 \text { pull. }+12 \\
\text { pull. }\end{array}$ & Szelle E. \\
\hline 2007.06.09. & Szeged, Fehér-tó & 8 & Domján A. \\
\hline 2007.06.11. & $\begin{array}{l}\text { Királyszentistván, Füzföi Szennyvíz Kft. } \\
\text { utótisztító tava }\end{array}$ & 1 pár + 9 pull. & Szelle E. \\
\hline 2007.06.11. & Szeged, Fehér-tó & 3 & Szücs P. \\
\hline 2007.06.12-13. & Királyszentistván, Füzföi Szennyvíz Kft. & 1 pár +9 pull. + & Szelle E. \\
\hline
\end{tabular}




\begin{tabular}{|c|c|c|c|}
\hline & utótisztító tava & 11 pull. & \\
\hline 2007.06 .13 & Pusztaszer, Büdös-szék & 1 & Tölgyesi Cs. \\
\hline 2007.06 .15 . & Fertőújlak, Nyéki-szállás & 1 & Németh M. \\
\hline 2007.06 .15 . & $\begin{array}{l}\text { Királyszentistván, Füzföi Szennyvíz Kft. } \\
\text { utótisztító tava }\end{array}$ & $\begin{array}{l}1 \text { pár }+9 \text { pull. }+5 \\
\text { pull. }\end{array}$ & Szelle E. \\
\hline 2007.06 .16 & Dunatetétlen, Böddi-szék & 8 & $\begin{array}{l}\text { Eőry M., Felföldi T., Hertelendy L., Sztakó A., } \\
\text { Nyúl M., }\end{array}$ \\
\hline 2007.06 .16 & $\begin{array}{l}\text { Királyszentistván, Füzfôii Szennyvíz Kft. } \\
\text { utótisztító tava }\end{array}$ & $\begin{array}{l}1 \text { pár }+9 \text { pull. }+10 \\
\text { pull. }\end{array}$ & Szelle E. \\
\hline 2007.06 .16 . & Szeged, Fehér-tó & 5 & Szücs P., Godács K. \\
\hline 2007.06 .17$. & Szeged, Fehér-tó & 6 & Kókai K. \\
\hline 2007.06 .18 & $\begin{array}{l}\text { Királyszentistván, Füzfői Szennyvíz Kft. } \\
\text { utótisztító tava }\end{array}$ & $\begin{array}{l}1 \text { pár }+9 \text { pull. }+10 \\
\text { pull. }\end{array}$ & Szelle E. \\
\hline 2007.06.19. & Szeged, Fehér-tó & 6 & Gyarmati G. \\
\hline 2007.06.19-20. & $\begin{array}{l}\text { Királyszentistván, Füzfői Szennyvíz Kft. } \\
\text { utótisztító tava }\end{array}$ & $\begin{array}{l}1 \text { pár }+9 \text { pull. }+9 \\
\text { pull. }\end{array}$ & Szelle E. \\
\hline 2007.06 .21 & Fertőújlak, Pap-rét & 1 ad. tojó + 1 pull. & Pellinger A., Tamás Á. \\
\hline 2007.06.21. & $\begin{array}{l}\text { Királyszentistván, Füzfői Szennyvíz Kft. } \\
\text { utótisztító tava }\end{array}$ & 2 ad. & Szelle E. \\
\hline 2007.06 .22 & Szeged, Fehér-tó & 1 & Engi L., Mészáros Cs. \\
\hline 2007.06 .23 & Kaba, cukorgyári ülepítők & $1 \mathrm{imm}$. & Emri T. \\
\hline 2007.06 .23 . & $\begin{array}{l}\text { Királyszentistván, Füzfői Szennyvíz Kft. } \\
\text { utótisztító tava }\end{array}$ & $\begin{array}{l}1 \text { pár }+9 \text { pull. }+9 \\
\text { pull. }\end{array}$ & Szelle E. \\
\hline 2007.06.24. & Szeged, Szegedi-Fertő & 2 & Domján A. \\
\hline $2007.06 .25-26$. & $\begin{array}{l}\text { Királyszentistván, Füzfooi Szennyvíz Kft. } \\
\text { utótisztító tava }\end{array}$ & $\begin{array}{l}1 \text { pár }+9 \text { pull. }+9 \\
\text { pull. }\end{array}$ & Szelle E. \\
\hline 2007.06 .26 & Fertőújlak, Nyéki-szállás és Pap-rét & $2 \mathrm{ad}$ & Szász E., Tamás Á. \\
\hline 2007.06 .26 & Szeged, Fehér-tó & 3 & Mészáros Cs. \\
\hline 2007.06 .28 & $\begin{array}{l}\text { Királyszentistván, Füzföi Szennyvíz Kft. } \\
\text { utótisztító tava }\end{array}$ & $\begin{array}{l}1 \text { pár }+9 \text { pull. }+9 \\
\text { pull. }\end{array}$ & Szelle E. \\
\hline 2007.06 .29 & $\begin{array}{l}\text { Királyszentistván, Füzföi Szennyvíz Kft. } \\
\text { utótisztító tava }\end{array}$ & $\begin{array}{l}1 \text { pár }+9 \text { pull. }+8 \\
\text { pull. }\end{array}$ & Szelle E. \\
\hline 2007.06 .30 & Fertőújlak, Pap-rét & $2 \mathrm{ad}$ & Tamás Á. \\
\hline 2007.06 .30 & $\begin{array}{l}\text { Királyszentistván, Füzfooi Szennyvíz Kft. } \\
\text { utótisztító tava }\end{array}$ & $\begin{array}{l}1 \text { pár }+9 \text { pull. }+7 \\
\text { pull. }\end{array}$ & Szelle E. \\
\hline
\end{tabular}

\subsection{Mandarinréce (Aix galericulata)}

A faj valamennyi adata minden valószínűség szerint fogságból szökött madarakra vonatkozik (E kategória). Megjegyzendő, hogy a valószínüsíthetően fogsági eredet miatt az adatok jelentős része nem is kerül rögzítésre a birding.hu oldalon. Érdekesség, hogy március közepétől júniusig a Soproni-hegységben lévő Fehér úti tavon tartózkodott egy pár, párzásukat is megfigyelték, de fiókákat, illetve biztos költést végül nem sikerült regisztrálni (később kiderült, hogy a madarak valószínüleg egy ágfalvi tartótól szöktek meg).

\begin{tabular}{|c|c|c|}
\hline 2006.11 .11 & Geszt, Begécsi-víztároló & 1 ad. hím (E) \\
\hline $\begin{array}{l}2006.12 .02- \\
2007.02 .09\end{array}$ & Pilisvörösvár, Nagy-tó & 1 ad. hím (E) \\
\hline 2007.01 .27 & Budapest, Duna & 1 pár $(\mathrm{E})$ \\
\hline $2007.02 .10 .^{*}$ & Budapest, Duna (Margit-sziget) & 1 pár $(\mathrm{E})$ \\
\hline 2007.03.18-25. & Sopron, Soproni-hegység (Fehér úti tó) & 1 ad. hím (E) \\
\hline $2007.04 .05-24 . *$ & Budapest, Naplás-tó & 1 tojó $(\mathrm{E})$ \\
\hline 2007.04.08.* & Kunmadaras, Pincés & 1 ad. hím (E) \\
\hline 2007.05.13-14. & Sopron, Soproni-hegység (Fehér úti tó) & 1 pár $(\mathrm{E})$ \\
\hline 2007.05.18. & Sopron, Soproni-hegység (Fehér úti tó) & 1 pár $(\mathrm{E})$ \\
\hline 2007.05 .19 & Sopron, Soproni-hegység (Fehér úti tó) & 1 tojó $(\mathrm{E})$ \\
\hline 2007.05.27. & Sopron, Soproni-hegység (Fehér úti tó) & 1 pár $(\mathrm{E})$ \\
\hline 2007.05.30-06.01. & Sopron, Soproni-hegység (Fehér úti tó) & 1 pár $(\mathrm{E})$ \\
\hline 2007.06.23. & Sopron, Soproni-hegység (Fehér úti tó) & 1 ad. tojó $(\mathrm{E})$ \\
\hline 2007.06 .25 . & Sopron, Soproni-hegység (Fehér úti tó) & 1 ad. tojó (E) \\
\hline
\end{tabular}

Molnár Sz., Simay G., Vasas A.

Pándi G., Pándi T.

Turny Z.

Szász E., Szász A.; Tamás Á.; Horváth B., Szolnyik Cs.

Hadarics T.; Redella B., Hadarics Sz.

Németh M., Redella B.

Németh M., Redella B.

Balázs M., Mészáros J., Kárász B., Tamás

Á., Szász E.

Németh M., Redella B.; Illés G., Pálinkás

A., Tamás Á.

Árvai G., Bruckner A., Bruckner M., P. I.,

P. A., Galambos M.

Németh M.

\subsection{Kisasszonyréce (Aix sponsa)}

A szezon néhány adata a tavaszi időszakból származik. Minden bizonnyal fogságból szökött példányokról lehet szó (E kategória), ezért az adatok jelentős része nem is kerül 
rögzítésre a birding.hu oldalon, illetve a Nomenclator Bizottsághoz sem nyújtják be azokat hitelesítésre. A Dinnyési-halastavakon költött egy pár, május végén és június elején figyelték meg a fiókákat vezető tojót.

\begin{tabular}{|c|c|}
\hline 2007.04.18.* & Kapuvár, Csíkos-égeres \\
\hline 2007.04.30.* & Hövej, bányató \\
\hline 2007.05 .27 & Dinnyés, Dinnyési-halastavak \\
\hline 2007.06 .02 . & Dinnyés, Dinnyési-halastavak \\
\hline 007.06.09. & Dinnyés, Dinnyési-halastavak \\
\hline
\end{tabular}

\author{
3 ad. hím (E) \\ 2 hím +1 tojó $(\mathrm{E})$ \\ 1 ad. tojó +10 pull. Szegedy I \\ (E) \\ 1 ad. tojó +10 pull. Szegedy I. \\ (E) \\ 1 ad. tojó +8 pull. Abonyi O., Szegedy I.
}

(E)

\subsection{2. Üstökösréce (Netta rufina)}

A faj rendszeresen költ a Dunántúl egyes vizein, így a Fertőn, a Velencei-tavon és a KisBalatonon, de fészkelése egyes kisebb tavakon is valószínü, pl. 2007-ben költött a NyirkaiHanyban. Az Alföldön még mindig viszonylag ritkának számít, de 2007-ben költött a Péteri-tavon. Dunántúli fészkelése és gyakorisága miatt adatait csak ritkán töltik fel a www.birding.hu oldalra, így az itt közölt adatsor meglehetősen hiányos, ennél jóval gyakoribb madárnak számít a Dunántúlon (májusban és június elején például több száz példány tartózkodott a fertőújlaki élöhely-rekonstrukciós területen, illetve Dinnyésen).

\begin{tabular}{|c|c|c|c|}
\hline 2006.07 .08 & Dinnyés, Dinnyési-halastavak & 6 & Raksányi Zs., Nagy Cs., Hortó E. \\
\hline 2006.07 .08 & Nagykanizsa, Miklósfai-halastavak & 5 hím + 1 tojó/juv. & Cser Sz., Talabér G., Faragó Á. \\
\hline 2006.07.10. & Fertőújlak, Borsodi-dülő & 3 & Árvai G., Árvainé Tóth I. \\
\hline 2006.07.11. & Szakmár, Dzsidva-halastó & $\begin{array}{l}4 \text { hím }+1 \text { tojó }+2 \\
\text { juv. }\end{array}$ & Tamás Á. \\
\hline 2006.07 .12 & Fertőújlak, Borsodi-dülő & $\begin{array}{l}5 \text { család ( } 1 \text { pull. }+2 \\
\text { pull. }+3 \text { pull. }+5 \\
\text { pull. }+6 \text { pull. })\end{array}$ & Hadarics T. \\
\hline 2006.07.12. & Tata, Réti-halastavak & 18 & Bátky G., Szeimann P. \\
\hline 2006.07 .14 & Nagykanizsa, Miklósfai-halastavak & 1 & Cser Sz., Gál Sz., Faragó Á. \\
\hline 2006.07 .16 & Tömörkény, Csaj-tó & 1 ad. tojó & Gyarmati G. \\
\hline 2006.07 .19 & Hortobágy, Hortobágyi-halastó & 3 & Dobi A., Harangi S., Nagy L., Borza S. \\
\hline 2006.07.22. & Harkakötöny, Harkai-tó & 2 juv. & Kiss $\mathrm{T}$. \\
\hline 2006.07 .25 & Seregélyes, Elza-major & 2 & Szalai K. \\
\hline 2006.08 .09 & Szakmár, Dzsidva-halastó & 1 ad. tojó +5 pull. & Tamás Á. \\
\hline 2006.08 .12 & Biatorbágy, halastavak & 1 ad. tojó + 3 juv. & Ungi B. \\
\hline 2006.08 .13 & Tömörkény, Csaj-tó & 5 & Ampovics Zs., Domján A. \\
\hline 2006.08 .14 & Kardoskút, Fehér-tó & 3 tojó & Szücs P. \\
\hline 2006.08 .14 & Zalavár, Kis-Balaton (II. ütem) & 2 tojó & Cser Sz., Gál Sz., Faragó Á. \\
\hline 2006.08 .18 & Dinnyés, Dinnyési-halastavak & 125 & Szél L., Kiss Á. \\
\hline 2006.08 .18 & Sárkeresztúr, Sárkány-tó & 2 tojó & Szél L., Kiss Á. \\
\hline 2006.08 .22 & Zalavár, Kis-Balaton (II. ütem) & 1 tojó +1 juv. hím & Cser Sz., Gál Sz., Faragó Á. \\
\hline 2006.08 .27 & Nagykanizsa, Miklósfai-halastavak & 3 & Cser Sz., Gál Sz. \\
\hline 2006.08 .27 & Tömörkény, Csaj-tó & 2 juv. & Domján A. \\
\hline 2006.08 .28 & Rétszilas, Rétszilasi-halastavak & 1 & Vasuta G., Kocsis K. \\
\hline 2006.08 .30 & Szakmár, Dzsidva-halastó & 1 ad. tojó +6 juv. & Tamás Á. \\
\hline 2006.09.02. & Dinnyés, Dinnyési-halastavak & 20 & Raksányi Zs., Raksányi K. \\
\hline 2006.09 .06 & Nagykanizsa, Miklósfai-halastavak & 1 ad. tojó & Cser Sz., Faragó Á., Gál Sz. \\
\hline 2006.09 .08 & Poroszló, Tisza-tó & 1 ad. hím & Sali I. \\
\hline 2006.09 .08 & Zalavár, Kis-Balaton (Zimány) & 2 & Cser Sz., Gál Sz. \\
\hline 2006.09.09. & Dinnyés, Dinnyési-halastavak & 120 & Szegedy I. \\
\hline 2006.09 .09 & Rétszilas, Rétszilasi-halastavak & 1 ad. tojó & Budavári L., Losonci E. \\
\hline 2006.09 .13 & Nagykanizsa, Miklósfai-halastavak & 4 & Faragó Á., Gál Sz. \\
\hline 2006.09 .17 & Balatonföldvár, Balaton & 5 ad. & Szöllősi P. \\
\hline 2006.09.17. & Nagykanizsa, Miklósfai-halastavak & 3 & $\begin{array}{l}\text { Gál Sz., Cser Sz., Faragó Á., Talabér G., } \\
\text { Maros S. }\end{array}$ \\
\hline 2006.09 .17 & Sárkeresztúr, Sárkány-tó & 1 pár & Oláh S., Szalai K. \\
\hline 2006.09 .18 & Zalavár, Kis-Balaton (I. ütem) & 1 & Faragó Á., Gál Sz. \\
\hline 2006.09 .18 & Zalavár, Kis-Balaton (II. ütem) & 3 & Faragó Á., Gál Sz. \\
\hline 2006.09 .26 & Fertőújlak, Borsodi-dülő & 11 & Agócs P., Benei Zs., Tamás Á. \\
\hline 2006.09.30. & Nagykanizsa, Miklósfai-halastavak & 6 & Gál Sz., Talabér G. \\
\hline 2006.10 .03 . & Zalavár, Kis-Balaton (II. ütem) & 1 ad. tojó & Faragó Á., Gál Sz. \\
\hline 2006.10 .07 & Fonyódliget, Balaton & 1 pár & Cser Sz., Faragó Á., Gál Sz. \\
\hline 2006.10 .07$. & Szántód, Balaton & 2 hím +3 tojó & Cser Sz., Faragó Á., Gál Sz. \\
\hline 2006.10 .07 & Várpalota, bányatavak & 4 & Szelle E. és társai \\
\hline 2006.10 .14 & Balatonboglár, Balaton & 60 & Kovács Gy., Pálmai O., Pálmai J. \\
\hline 2006.10 .15 . & Mikepércs, Tócó-Kösely menti víztároló & 1 ad. hím & Pásti Cs. \\
\hline 2006.10 .15 . & Rétszilas, Rétszilasi-halastavak & 1 tojó & Mészáros J., Staudinger I., Cserna Z., Takács \\
\hline
\end{tabular}




\begin{tabular}{|c|c|c|c|}
\hline & & & Á. \\
\hline 2006.10 .19 & Geszt, Begécsi-víztároló & 1 ad. hím & Tóth I. \\
\hline 2006.10 .21 & Fenékpuszta, Balaton & 3 & Cser Sz., Faragó Á., Gál Sz. \\
\hline 2006.10 .21 & Fonyód, Balaton & 2 & Cser Sz., Faragó Á., Gál Sz. \\
\hline 2006.10 .23 & Nagykanizsa, Miklósfai-halastavak & 1 ad. hím & Cser Sz., Faragó Á., Gál Sz. \\
\hline 2006.10 .23 & Rétszilas, Rétszilasi-halastavak & 1 tojó & Árvai G. \\
\hline 2006.10 .29 & Nagykanizsa, Miklósfai-halastavak & 1 tojó & Faragó Á., Gál Sz. \\
\hline 2006.10 .30 & Balatonföldvár, Balaton & 2 & Bordé S.; Németh F. \\
\hline 2006.11 .01 & Szántód, Balaton & 2 & Szöllősi P. \\
\hline 2006.11 .04 & Hahót, tőzegbányatavak & 1 hím & Cser Sz., Gál Sz. \\
\hline 2006.11 .08 & Geszt, Begécsi-víztároló & 1 ad. hím & Tóth I. \\
\hline 2006.11.09. & Fonyód, Balaton & 5 hím +1 tojó & Cser Sz., Faragó Á., Gál Sz. \\
\hline 2006.11 .12 & Balatonszárszó, Balaton & 1 tojó & Berényi Zs. \\
\hline 2006.11 .18 & Soponya, Soponyai-halastavak & 1 ad. hím & $\begin{array}{l}\text { Bodor G., Horváth G., Porkoláb M.; Mészáros } \\
\text { J., Staudinger I., Cserna Z. }\end{array}$ \\
\hline 2006.11 .18 & Várpalota, horgásztó & 4 ad. hím +4 ad. tojó & Barta Z., Széplaki I. \\
\hline 2006.11 .19 & Rétszilas, Rétszilasi-halastavak & 1 & Mészáros J., Staudinger I., Nagy I. \\
\hline 2006.12 .02 & Balatonőszöd, Balaton & 1 & $\begin{array}{l}\text { Berényi Zs., Cser Sz., Gál Sz., Horváth G., } \\
\text { Mészáros J., Porkoláb M., Ungi B., M. } \\
\text { Kusterer }\end{array}$ \\
\hline 2006.12 .03 & $\begin{array}{l}\text { Királyszentistván, Füzföi Szennyvíz Kft. } \\
\text { utótisztító tava }\end{array}$ & 1 juv. & Szelle E. \\
\hline 2006.12 .09 . & Fonyód, Balaton & 1 ad. hím & Cser Sz., Faragó Á., Gál Sz. \\
\hline 2006.12 .29 . & Szeged, Fehér-tó & 1 & Lázár B., Bérdi G., Gyarmati G. \\
\hline 2006.12 .30 & Szántód, Balaton & 1 tojó & Laczik D., Sebe K. \\
\hline 2006.12 .31 & Fonyódliget, Balaton & 3 & Cser Sz., Gál Sz., Talabér G., Kancsal B. \\
\hline $2007.01 .06-07$. & Szántód, Balaton & 1 ad. tojó & $\begin{array}{l}\text { Hernádi L.; Barkóczi Cs., Fodor A., Gyarmati } \\
\text { G. }\end{array}$ \\
\hline 2007.01 .15 . & Várpalota, horgásztó & 2 ad. hím +3 ad. tojó & Barta Z. \\
\hline 2007.01 .17 & Fenékpuszta, Balaton & 2 pár & Vasuta G., Kocsis K. \\
\hline 2007.01.20. & Szántód, Balaton & 1 tojó & $\begin{array}{l}\text { Bajor Z., Bodor G., Horváth G., Kardos K., } \\
\text { Porkoláb M. }\end{array}$ \\
\hline 2007.01 .28 & Várpalota, halastavak & 1 hím +2 tojó & Henger $\mathrm{K}$. \\
\hline 2007.02 .12 & Kiskunlacháza, bányatavak & 3 & Ampovics Zs. \\
\hline 2007.02 .15 & Dinnyés, Dinnyési-halastavak & 9 & Kiss Á. \\
\hline 2007.02 .17 & Balatonboglár, Balaton & 5 hím +2 tojó & Kovács Gy., Kapitány M. \\
\hline 2007.02 .17 & Nagykanizsa, Miklósfai-halastavak & 2 hím +1 tojó & Faragó Á., Gál Sz. \\
\hline 2007.02 .18 & Fonyód, Balaton & 18 & Cser Sz., Faragó Á., Gál Sz. \\
\hline 2007.02.18. & Rétszilas, Rétszilasi-halastavak & 10 & $\begin{array}{l}\text { Mészáros J., Staudinger I., Cserna Z., Farkas } \\
\text { L. }\end{array}$ \\
\hline 2007.02.23. & Nagykanizsa, Miklósfai-halastavak & 1 hím +1 tojó & Faragó Á., Gál Sz. \\
\hline 2007.02 .25 & Dinnyés, Dinnyési-halastavak & 3 pár & Szegedy I. \\
\hline 2007.03 .03 & Balatonföldvár, Balaton & 1 pár & Kovács Gy. \\
\hline 2007.03 .03 & Balatonszárszó, berek & 3 hím +1 tojó & Kovács Gy. \\
\hline 2007.03.03. & Kiskunlacháza, bányatavak & $2 \mathrm{ad}$ & $\begin{array}{l}\text { Bodor G., Horváth G., Porkoláb M., Selmeczi } \\
\text { Kovács Á., Steiner A. }\end{array}$ \\
\hline 2007.03 .08 & Apaj, Szúnyog-puszta & 1 tojó & Kókay B. \\
\hline 2007.03 .10 & Nagykanizsa, Miklósfai-halastavak & 5 & Cser Sz., Faragó Á., Gál Sz., Talabér G. \\
\hline 2007.03 .10 . & Zalavár, Kis-Balaton (II. ütem) & 1 ad. hím & Cser Sz., Faragó Á., Gál Sz., Talabér G. \\
\hline 2007.03 .11 & Pákozd, Velencei-tó & 1 hím +1 tojó & Király E., Bodrogi Zs. \\
\hline 2007.03 .12 & Apaj, árasztások & 1 pár & Kiss Á. \\
\hline 2007.03 .12 & Hahót, tőzegbányatavak & 6 & Gál Sz. \\
\hline 2007.03 .13 . & Apaj, Apaj-puszta & $4 \mathrm{ad}$. & Kókay B. \\
\hline 2007.03 .15 . & Nagykanizsa, Miklósfai-halastavak & 5 pár & Faragó Á., Gál Sz., Talabér G. \\
\hline 2007.03 .17 . & Balatonmagyaród, Kis-Balaton (II. ütem) & 2 & Cser Sz., Faragó Á., Gál Sz., Talabér G. \\
\hline 2007.03 .17$. & Soponya, Soponyai-halastavak & 13 & Mészáros J., Staudinger I. \\
\hline 2007.03 .17 . & Sumony, Sumonyi-halastó & 4 hím & Madas K., Oltai L., Onodi M., \\
\hline 2007.03 .17 & Szakmár, Dzsidva-halastó & 6 ad. hím +3 ad. tojó & Tamás Á. \\
\hline 2007.03 .17 & Várpalota, bányatavak & 1 pár & Barta Z. \\
\hline 2007.03 .22 & Dunaszeg, horgásztó & 1 tojó & Hernádi L. \\
\hline 2007.03.25. & Apaj, árasztások & 6 & Kiss Á., Takács Á. \\
\hline $2007.03 .25-26$. & Szeged, Szegedi-Fertő & 1 hím +1 tojó & Domján A.; Kiss O., Tokody B.; Engi L. \\
\hline 2007.03 .27 & Fertőújlak, Borsodi-dülő & 8 & Hadarics T. \\
\hline 2007.03.28. & Várpalota, bányatavak & 6 pár & Barta Z., Béres L. \\
\hline 2007.03.29. & Apaj, árasztások & 4 hím +3 tojó & $\begin{array}{l}\text { Balogh F., Kovács I., Szeghalmi J., Szegedy } \\
\text { I. }\end{array}$ \\
\hline 2007.03.29. & Hortobágy, Hortobágyi-halastó & 5 & Nagy G. G. \\
\hline 2007.03.31. & Fertőrákos, Rákos-csatorna & 1 ad. hím & Hadarics T. \\
\hline 2007.03 .31 & Osli, Hansági-föcsatorna & 1 pár & Kása R. \\
\hline 2007.04 .01 & Bősárkány, Nyirkai-Hany & 7 & Hunyadi L. \\
\hline 2007.04 .01 & Dinnyés, Dinnyési-halastavak & 54 hím + 11 tojó & Szegedy I. \\
\hline 2007.04.01. & Tata, Réti-halastavak & 2 & Szeimann P. \\
\hline 2007.04 .02 . & Balatonlelle, Irmapusztai-halastavak & 33 & Kovács Gy. \\
\hline 2007.04 .02 . & Hortobágy, Hortobágyi-halastó & 1 pár & Balázsi P., Gilányi G. \\
\hline 2007.04 .05 & Balatonmagyaród, Kis-Balaton (II. ütem) & 4 & Faragó Á., Gál Sz. \\
\hline 2007.04 .05 & Harkakötöny, Harkai-tó & 1 pár & Kiss P., Kiss T. \\
\hline
\end{tabular}




\begin{tabular}{|c|c|c|c|}
\hline 2007.04.06. & Balatonmagyaród, Zala & 1 ad. hím & Árvai G., Bruckner A. és társaik \\
\hline 2007.04.06. & Hortobágy, Csécsi-halastó & 1 ad. hím & Kovács G. K. \\
\hline 2007.04.06. & Nagykanizsa, Miklósfai-halastavak & 14 & Gál Sz. \\
\hline 2007.04.06. & Naszály, Ferencmajori-halastavak & 13 hím + 7 tojó & Riezing N. \\
\hline 2007.04.06. & Szakmár, Dzsidva-halastó & 4 ad. hím +2 ad. tojó & Csontos D., Tamás Á. \\
\hline 2007.04.07. & Hortobágy, Hortobágyi-halastó (Kondás) & 1 hím & Nagy M. \\
\hline 2007.04.07. & Zalavár, Balatonhídvég & 2 ad. & Bruckner A. \\
\hline 2007.04.08. & Rétszilas, Rétszilasi-halastavak & 2 hím + 1 tojó & Vasuta G. \\
\hline 2007.04.10. & Apaj, Apaj-puszta & 5 & Bordé S.; Németh F. \\
\hline 2007.04.11. & Szakmár, Dzsidva-halastó & 5 hím +3 tojó & Agócs P., Tamás Á. \\
\hline 2007.04.11. & Várpalota, horgásztó & 2 hím & Vasuta G., Kocsis K. \\
\hline 2007.04.12. & Balatonlelle, Irmapusztai-halastavak & 43 & Kovács Gy. \\
\hline 2007.04.14. & Apaj, árasztások & 2 & Takács Á. \\
\hline 2007.04.14. & Balatonőszöd, Balaton & 9 & $\begin{array}{l}\text { Laposa D., Hegedüs D., Bodor G., Horváth } \\
\text { G., Kókay B. }\end{array}$ \\
\hline 2007.04.14. & Soponya, Soponyai-halastavak & 22 & Mészáros J., Staudinger I. \\
\hline 2007.04.14. & Szántód, Balaton & 1 & $\begin{array}{l}\text { Laposa D., Hegedüs D., Bodor G., Horváth } \\
\text { G., Kókay B. }\end{array}$ \\
\hline 2007.04.14. & Tihany, Külső-tó & 2 & Korponai G. \\
\hline 2007.04.15. & Biatorbágy, halastavak & 2 & Ungi B. \\
\hline 2007.04.15. & Harkakötöny, Harkai-tó & 1 ad. hím & Baranyai J., Kiss T. \\
\hline 2007.04.15. & Rétszilas, Hérics & 3 & Mészáros J., Staudinger I., Farkas L. \\
\hline 2007.04.15. & Rétszilas, Rétszilasi-halastavak & 24 & Mészáros J., Staudinger I., Farkas L. \\
\hline 2007.04.15. & Sumony, Sumonyi-halastó & 5 & Ónodi M., Pinczehelyi J. \\
\hline 2007.04.15. & $\begin{array}{l}\text { Szombathely, gyöngyöshermáni } \\
\text { kavicsbányató }\end{array}$ & 1 pár & Kis P. \\
\hline 2007.04.16. & Apaj, árasztások & 3 & Szél L., Kiss Á. \\
\hline 2007.04.19. & Balatonlelle, Irmapusztai-halastavak & 56 & Kovács Gy. \\
\hline 2007.04.19. & Naszály, Ferencmajori-halastavak & 12 & Riezing N. \\
\hline 2007.04.22. & Apaj, Ürbői-halastavak & 3 & Ungi B., Fodor A. \\
\hline 2007.04.22. & Tata, Réti-halastavak & 6 hím & Szeimann P. \\
\hline 2007.04.23. & $\begin{array}{l}\text { Királyszentistván, Füzfői Szennyvíz Kft. } \\
\text { utótisztító tava }\end{array}$ & 1 pár & Szelle E. \\
\hline 2007.04.23. & Zamárdi, Balaton & 1 tojó & Jakus L. \\
\hline 2007.04.25. & $\begin{array}{l}\text { Királyszentistván, Fúzfői Szennyvíz Kft. } \\
\text { utótisztító tava }\end{array}$ & 1 pár & Szelle E. \\
\hline 2007.04.25. & Naszály, Ferencmajori-halastavak & 2 & Riezing N. \\
\hline 2007.04.28. & Balatonhídvég, Kis-Balaton & $3 \mathrm{ad}$. & $\begin{array}{l}\text { Szeghalmi J., Kovács I., Juhász I., Deák- } \\
\text { Bárdos I., Balogh F. }\end{array}$ \\
\hline 2007.04.28. & $\begin{array}{l}\text { Királyszentistván, Fúzfőii Szennyvíz Kft. } \\
\text { utótisztító tava }\end{array}$ & 1 pár & Szelle E. \\
\hline 2007.04.28. & Rétszilas, Rétszilasi-halastavak & 25 & Árvai G., Bruckner A. és társaik \\
\hline 2007.04.28. & Szakmár, Dzsidva-halastó & 4 ad. hím +2 ad. tojó & Tamás Á. \\
\hline 2007.04.29-30. & Zalavár, Kis-Balaton (II. ütem) & 2 & Kiss Á., Kardos É., Kiss J. \\
\hline 2007.04.30. & Apaj, Szúnyog-puszta & 2 & Pintér B., Verseczki N. \\
\hline 2007.04.30. & Szakmár, Dzsidva-halastó & 6 ad. hím +5 ad. tojó & Tamás Z.-né, Tamás Á. \\
\hline 2007.04.30. & Zalaszabar, Kis-Balaton (I. ütem) & 2 & Kiss Á., Kardos É., Kiss J. \\
\hline 2007.05 .01 & Balatonlelle, Irmapusztai-halastavak & 63 & Kovács Gy. \\
\hline 2007.05.01. & Dinnyés, Dinnyési-halastavak & 183 hím + 71 tojó & Szegedy I. \\
\hline 2007.05 .01 & Hortobágy, Hortobágyi-halastó (Kondás) & 1 ad. hím & Nagy M. \\
\hline 2007.05.03. & Naszály, Ferencmajori-halastavak & 5 & Riezing N. \\
\hline 2007.05 .04 . & Apaj, Apaj-puszta & 3 & Szél L., Kiss Á. \\
\hline 2007.05.05. & $\begin{array}{l}\text { Királyszentistván, Füzfői Szennyvíz Kft. } \\
\text { utótisztító tava }\end{array}$ & 1 pár & Szelle E. \\
\hline 2007.05.06. & Apaj, árasztások & 2 & Mészáros J., Barna M., Takács Á. \\
\hline 2007.05.06. & Fertőújlak, Nyéki-szállás & 18 & Németh M., Redella B. \\
\hline 2007.05.07. & Apaj, árasztások & $4 \mathrm{ad}$. & Bordé S.; Németh F. \\
\hline 2007.05.10. & $\begin{array}{l}\text { Királyszentistván, Füzfői Szennyvíz Kft. } \\
\text { utótisztító tava }\end{array}$ & 1 pár & Szelle E. \\
\hline 2007.05.11. & Kis-Balaton & 1 pár + 3 hím & A. L., Nagy G. G. \\
\hline 2007.05.13. & Biatorbágy, halastavak & 2 pár + 3 hím & Ungi B. \\
\hline 2007.05.14. & Fertőújlak, Nyéki-szállás & 115 & Vasuta G., Kocsis K. \\
\hline 2007.05.14. & Sumony, Sumonyi-halastó & 1 hím & Ónodi M. \\
\hline 2007.05.21. & Bősárkány, Nyirkai-Hany & 1 tojó +8 pull. & Mogyorósi S., Molnár Sz. \\
\hline 2007.05.22. & Balatonlelle, Irmapusztai-halastavak & 37 & Kovács Gy. \\
\hline 2007.05.23. & Zalavár, Kis-Balaton & 1 ad. hím & Nagy G. G. \\
\hline 2007.05.26. & Fertőújlak, Körgát & $\begin{array}{l}3 \text { ad. tojó }+10 \text { pull. }+1 \\
13 \text { pull. }+4 \text { pull. }\end{array}$ & Mogyorósi S. \\
\hline 2007.05.27. & Dinnyés, Dinnyési-halastavak & 79 & Szegedy I. \\
\hline 2007.05.27. & Fertőújlak, Nyéki-szállás & 250 & $\begin{array}{l}\text { Mészáros J., Barna M., Kárász B., Szász E., } \\
\text { Tamás Á. }\end{array}$ \\
\hline 2007.05.28. & Bősárkány, Nyirkai-Hany & 8 & Kiss Á., Kardos É., Kiss J. \\
\hline 2007.05.28. & Fertőújlak, Nyéki-szállás & 210 & Németh M., Redella B. \\
\hline 2007.05.29. & Fertőújlak, Pap-rét és Nyéki-szállás & 490 & Pellinger A., Tamás Á. \\
\hline 2007.05.31. & Rétszilas, Rétszilasi-halastavak & 1 & Árvai G., Árvainé Tóth I. \\
\hline 2007.06.02. & Dinnyés, Dinnyési-halastavak & 63 hím +12 tojó & Szegedy I. \\
\hline
\end{tabular}




\begin{tabular}{|c|c|c|c|}
\hline 2007.06 .02$. & Petőfiszállás, Péteri-tó & 1 ad. tojó +4 pull. & Tölgyesi Cs. \\
\hline 2007.06 .03 . & Fertőújlak, Nyéki-szállás & 300 & Németh M., Redella B. \\
\hline 2007.06.09. & Apaj, árasztások & 1 tojó & Gránicz L., Forintos N. \\
\hline 2007.06.09. & Balatonlelle, Irmapusztai-halastavak & 63 & Kovács Gy. \\
\hline 2007.06.09. & Dinnyés, Dinnyési-halastavak & 147 & Abonyi O., Szegedy I. \\
\hline 2007.06.09. & Hortobágy, Hortobágyi-halastó & 3 hím +3 tojó & Emri T., Zöld B. \\
\hline 2007.06.11. & Fertőrákos, Fertő & 3 & Kárász B. \\
\hline 2007.06.15. & Balatonlelle, Irmapusztai-halastavak & 41 & Kovács Gy. \\
\hline 2007.06 .15 . & Fertőújlak, Nyéki-szállás & 18 & Németh M. \\
\hline 2007.06.16. & Biatorbágy, halastavak & 1 pár & Ungi B. \\
\hline 2007.06 .16 . & Szakmár, Dzsidva-halastó & 4 ad. +4 pull. & Tamás Á. \\
\hline 2007.06 .18 . & Sumony, Sumonyi-halastó & 5 & Ónodi M. \\
\hline 2007.06.23. & Dinnyés, Dinnyési-halastavak & 3 hím $+34+29$ pull. & Szegedy I. \\
\hline 2007.06 .23 . & Fertőújlak, Nyéki-szállás & 1 tojó & Árvai G., Bruckner A. \\
\hline
\end{tabular}

\subsection{3. Örvös réce (Aythya collaris)}

2003-as első hazai előfordulása után 2006 szeptemberében ismét feltünt egy hím példány Magyarországon, ezúttal a nagykanizsai Miklósfai-halastavakon. Az adatot a Nomenclator Bizottság a faj második hazai adataként $\mathrm{D}_{\mathrm{A}}$ kategóriában hitelesítette, azaz a madár vad eredetével kapcsolatban ugyan merültek fel kételyek (mint ahogy ez minden északamerikai eredetü récefajnál így van), de - bár nem zárható ki teljes bizonyossággal a fogságból való szökés sem - a példány nagyobb valószínűséggel inkább vad eredetű lehet.

$\begin{array}{lll}\text { 2006.09.17. } & \text { Nagykanizsa, Miklósfai-halastavak } & 1 \text { ad. hím }\left(D_{\mathrm{A}}\right) \\ \text { 2006.09.19. } & \text { Nagykanizsa, Miklósfai-halastavak } & 1 \text { ad. hím }\left(D_{\mathrm{A}}\right)\end{array}$

Gál Sz., Cser Sz., Faragó Á., Talabér G., Maros S.; Fehér F.

Faragó Á., Gál Sz., Berényi Zs., Horváth G., Koczka A., Nagy G., Selmeczi Kovács Á., Simay G., Steiner A., Weszelinov O.

\subsection{Hegyi réce (Aythya marila)}

Az előző szezonhoz képest némileg kevesebb megfigyelése gyült össze 2006/2007-ben, és a legnagyobb csapatnagyság tekintetében is elmondható, hogy az nem érte el az elöző évieket (de laglábbis kevesebb alkalommal láttak nagyobb csapatokat). Összel az első példányokat már október elején látták, de csak a hónap közepén és végén érkezett több kisebb csapat a vizes élőhelyekre. Az adatok zöme novemberből és decemberből való. Legtöbb adata most is a Balatonról származik, és a legnagyobb csapatokat is itt látták: Szántódon 2006. november 26 -án 60 példányt, 2006. december 2-án 75 példány, Tihanynál 2006. december 10-én 140 példányt, 2006. december 11-12-én 158 példányt, Balatonberénynél 2007. január 4-én 63 példányt, 2007. január 17-én 60 példányt, Fenékpusztánál 2007. január 20-án 75 példányt számoltak. Tavasszal márciusban csak a Hortobágyi-halastavon, április elején pedig egy alkalommal a siófoki Töreki-halastavon észlelték.

$\begin{array}{llll}2006.10 .07 . & \text { Fonyód, Balaton } & 1 \text { hím }+2 \text { tojó } & \text { Cser Sz., Faragó Á., Gál Sz. } \\ 2006.10 .08 . & \text { Fenékpuszta, Balaton } & 2 \text { hím }+1 \text { tojó } & \text { Cser Sz., Faragó Á, Gál Sz. } \\ 2006.10 .13 . & \text { Hatvan, cukorgyári ülepítők } & 1 \text { ad. tojó } & \text { Pintér B., Verseczki N. } \\ 2006.10 .14 . & \text { Fenékpuszta, Balaton } & 10 & \text { Cser Sz., Faragó Á, Gál Sz., Talabér G. } \\ 2006.10 .16 . & \text { Fenékpuszta, Balaton } & 2 & \text { Vasuta G., Kocsis K. } \\ 2006.10 .21 . & \text { Balatonöszöd, Balaton } & 1 & \text { Cser Sz., Faragó Á., Gál Sz. } \\ 2006.10 .21 . & \text { Szántód, Balaton } & 2 \text { ad. hím } & \text { Cser Sz., Faragó Á, Gál Sz. } \\ 2006.10 .21 . & \text { Szeged, Szegedi-Fertő } & 1 \text { ad. hím } & \text { Barócsi A. és társai } \\ 2006.10 .27 . & \text { Fenékpuszta, Balaton } & 10 & \text { Szeimann P. } \\ 2006.10 .27 . & \text { Szabadszállás, Zab-szék } & 1 \text { imm. hím + 2 tojó } & \text { Pigniczki Cs. } \\ 2006.10 .28 . & \text { Fenékpuszta, Balaton } & 4 & \text { Faragó Á., Gál Sz., Talabér G. } \\ 2006.10 .28 . & \text { Zalavár, Kis-Balaton } & 1 & \text { Faragó Á., Gál Sz., Talabér G. } \\ 2006.10 .31 . & \text { Fenékpuszta, Balaton } & 20 & \text { Cser Sz., Faragó Á., Gál Sz. } \\ 2006.11 .03 . & \text { Fertőújlak, Borsodi-dűlő } & 1 \text { imm. tojó } & \text { Hadarics T. } \\ 2006.11 .04 . & \text { Nagykanizsa, Miklósfai-halastavak } & 2 \text { juv. } & \text { Cser Sz., Gál Sz. } \\ 2006.11 .04 . & \text { Pilismarót, Duna (Pilismaróti-öböl) } & 1 \text { tojó } & \text { Takács Á. } \\ 2006.11 .05 . & \text { Geszt, Begécsi-víztároló } & 1 & \text { Molnár Sz., Vasas A. } \\ 2006.11 .05 . & \text { Szántód, Balaton } & 6 & \text { Szücs Cs., Fodor A., Lendvai Cs., Hegedüs D. } \\ 2006.11 .06 . & \text { Fenékpuszta, Balaton } & 5 & \text { Paprika A., Benke Sz., Szeimann P. } \\ 2006.11 .06 . & \text { Keszthely, Balaton (Keszthelyi-öböl) } & 5 & \text { Szeimann P. } \\ 2006.11 .07 . & \text { Fenékpuszta, Balaton } & 30 & \text { Faragó Á., Gál Sz. }\end{array}$




\author{
2006.11.08. \\ 2006.11.09. \\ 2006.11 .10 \\ 2006.11.10. \\ 2006.11.10. \\ 2006.11.12. \\ 2006.11.12. \\ 2006.11.13. \\ 2006.11.16. \\ 2006.11.17. \\ 2006.11.18. \\ 2006.11 .18 \\ 2006.11.18.
}

2006.11.18-19.

2006.11.19.

2006.11.19.

2006.11.20.

2006.11.21.

2006.11.25.

2006.11.25.

2006.11.25.

2006.11.25.

2006.11.26.

2006.11.27.

2006.11.27.

2006.11.28.

2006.11.29.

2006.12.01.

2006.12.02.

2006.12.04.

2006.12.05.

2006.12.06.

2006.12.09.

2006.12.10.

2006.12.10.

2006.12.10.

2006.12.10.

2006.12.11.

2006.12.11.

2006.12.11-12.

2006.12.14.

2006.12.15.

2006.12.15.

2006.12.16.

2006.12.20.

2006.12.22.

2006.12.23.

2006.12.23.

2006.12.23.

2006.12.24.

2006.12.24.

2006.12.27.

2006.12.27.

2006.12.27.

2006.12.28.

2006.12.29.

2006.12.30-31.

2006.12.31.

2007.01.02.

2007.01.03.

2007.01 .04 .

2007.01.05.

2007.01.05-06.

2007.01.06.

2007.01.06.

2007.01.06.

2007.01.08.
Fenékpuszta, Balaton

Balatonalmádi, Balaton

1 juv.

1 tojó

Keszthely, Balaton (Keszthelyi-öböl)

16

2 tojó

1 tojó

Balatonszárszó, Balaton

Tömörkény, Csaj-tó

Neszmély, Duna

Szántód, Balaton

Pilismarót, Duna (Pilismaróti-öböl)

Balmazújváros, Virágoskúti-halastó

Hortobágy, Hortobágyi-halastó

Keszthely, Balaton (Keszthelyi-öböl)

Sarud, Tisza-tó (Sarudi-medence)

Balatonberény, Balaton

Tihany, Balaton

Szeged, Szegedi-Fertő

Visegrád, Duna (Visegrádi-öböl)

Fonyód, Balaton

Siófok-Szabadisóstó, Balaton

Szántód, Balaton

Visegrád, Duna (Visegrádi-öböl)

Szántód, Balaton

Keszthely, Balaton (Keszthelyi-öböl)

Visegrád, Duna (Visegrádi-öböl)

Balatonfüred, Balaton

Balatonberény, Balaton

Devecser, Széki-tó

Szántód, Balaton

Nagykanizsa, Miklósfai-halastavak

Abádszalók, Tisza-tó (Abádszalóki-öböl)

Nyergesújfalu, Duna (Nyerges-sziget)

Hortobágy, Hortobágyi-halastó

Csopak, Balaton

Fenékpuszta, Balaton

Keszthely, Balaton (Keszthelyi-öböl)

Tihany, Balaton

Balatonföldvár, Balaton

Fenékpuszta, Balaton

Tihany, Balaton

Visegrád, Duna (Visegrádi-öböl)

Szántód, Balaton

Zamárdi, Balaton

Visegrád, Duna (Visegrádi-öböl)

Szántód, Balaton

Pilismarót, Duna (Pilismaróti-öböl)

Fenékpuszta, Balaton

Keszthely, Balaton (Keszthelyi-öböl)

Szántód, Balaton

Pilismarót, Duna (Pilismaróti-öböl)

Szeged, Szegedi-Fertő

Budakalász, bányatavak

Budapest, Duna

Tihany, Balaton (Fehér-part)

Tihany, Balaton (Gödrös)

Abádszalók, Tisza-tó (Abádszalóki-öböl) 1 hím +4 tojo

Pilismarót, Duna (Pilismaróti-öböl)

Balatonberény, Zala-torkolat

Pilismarót, Duna (Pilismaróti-öböl)

Pilismarót, Duna (Pilismaróti-öböl)

Balatonberény, Balaton

Pilismarót, Duna (Pilismaróti-öböl)

Budapest, Duna (Óbudai-sziget)

Balatonberény, Balaton

Hahót, tőzegbányatavak

Pilismarót, Duna (Pilismaróti-öböl)

Pilismarót, Duna (Pilismaróti-öböl)

63

2 hím +2 tojó

1 tojó

min. 60

3 hím +3 tojó
Vasuta G., Paprika A.

Cser Sz., Faragó Á., Gál Sz.

Cser Sz., Faragó Á., Gál Sz.

Cser Sz., Faragó A., Gál Sz.

Cser Sz., Faragó Á., Gál Sz.

Berényi Zs.

Barkóczi Cs

Csonka P.

Illés G., Pálinkás A.

Hegedüs D.

Simay A., Zalai T.

Balla D

Ampovics Zs., Cser Sz., Domján A., Faragó Á. Futó R., Gál Sz., Lisztes A., Németh T., Pánya

Cs., Pigniczki Cs., Valkó O.

Zalai T.; Rimóczi A.

Ampovics Zs., Domján A., Pigniczki Cs., Valkó

O.

Nagy L.

Kókai K.

Magyar G.

Kovács Gy.

Kókay B., Laposa D.

Kókay B., Laposa D.

Kiss Á.

Koczka A., Pánya Cs., Weszelinov O., Hegedüs

D.,

Szeimann P.

Selmeczi Kovács Á.; Hunyadi L.

Vasuta G., Kocsis K.

Vasuta G., Kocsis K

Vasuta G., Kocsis K.

Berényi Zs., Cser Sz., Gál Sz., Horváth G.

Mészáros J., Porkoláb M., Ungi B., M. Kusterer

Faragó Á., Gál Sz.

Rimóczi Á.

Csonka P.

Gyüre P.

Cser Sz., Faragó Á., Gál Sz.

Cser Sz., Faragó Á., Gál Sz.

Cser Sz., Faragó Á., Gál Sz.

Cser Sz., Faragó Á., Gál Sz.

Vasuta G., Kocsis K.

Vasuta G., Kocsis K.; Faragó Á., Gál Sz.

Vasuta G., Kocsis K

Kiss A., Szél L.

Forintos N.

Forintos N.

MME Budapesti HCs

Gyüre P., Török H. A., Weszelinov O.

Gránicz L., Forintos N.

Gál Sz., Talabér G., Cser Sz.

Gál Sz., Talabér G., Cser Sz.

Mészáros J., Barna M.

Bodor G., Horváth G., Lendvai Cs.

Kókai K.

Fehérvári P., Barcánfalvi P.

Pintér B., Selmeczi Kovács Á.

Korponai G.

Oláh S., Szalai K.

Bodzás J. S.

Fodor A., Riezing N.; Nagy G., Rottenhoffer I., Kókay B.

Cser Sz., Gál Sz., Talabér G., Kancsal B.

Takács Á.

2 hím +2 tojó

1 ad. hím +2 imm.

hím +4 tojó/juv.

1 hím +1 tojó

2 hím +1 tojó
Hadarics T., Udvardy F., Balaskó Zs.

Cser Sz., Faragó Á., Gál Sz.

Selmeczi Kovács Á.

Laposa D. és mások

Oláh J., Selmeczi Kovács Á., Tar J., Végvári

Zs., Zalai T.

Gál Sz.

Bodor G., Horváth G., Porkoláb M.

Balogh F., Szőke M., Nagy G. G., Rottenhoffer 


\begin{tabular}{|c|c|c|c|}
\hline 2007.01 .08 & Szob, Duna & 2 tojó & Nagy G. G., Rottenhoffer I. \\
\hline 2007.01.11. & Balatonszentgyörgy, Balaton & 45 & Mészáros Cs. és társai \\
\hline 2007.01.20. & Balatonberény, Balaton & 22 & Cser Sz., Gál Sz., Talabér G. \\
\hline 2007.01 .20 . & Fenékpuszta, Balaton & 75 & Cser Sz., Gál Sz., Talabér G., Paprika A. \\
\hline 2007.01 .21 & Balatonberény, Balaton & 15 & Kókay B. \\
\hline 2007.01 .31 & Abádszalók, Tisza-tó (Abádszalóki-öböl) & 1 hím +3 tojó & Rimóczi Á., Gődér R. \\
\hline 2007.02 .03 . & Abádszalók, Tisza-tó (Abádszalóki-öböl) & 2 hím +4 tojó & Bodzás J. S. \\
\hline 2007.02 .05 & Abádszalók, Tisza-tó (Abádszalóki-öböl) & 2 hím +3 tojó & Gődér R., Rimóczi Á. \\
\hline 2007.02 .05 & Balatonberény, Zala-torkolat & 5 hím +15 tojó & Vasuta G., Kocsis K. \\
\hline 2007.02 .06 . & Balatonberény, Balaton & 35 & Faragó Á., Gál Sz. \\
\hline 2007.02.18. & Abádszalók, Tisza-tó (Abádszalóki-öböl) & 5 tojó & Bodzás J. S. \\
\hline 2007.02 .18 & Balatonberény, Balaton & 10 & Cser Sz., Faragó Á., Gál Sz. \\
\hline 2007.02 .18 & Fonyód, Balaton & 2 & Cser Sz., Faragó Á., Gál Sz. \\
\hline 2007.02.19. & Pilismarót, Duna (Pilismaróti-öböl) & 6 hím +1 tojó & Selmeczi Kovács Á., Pintér B. \\
\hline 2007.02.23. & Abádszalók, Tisza-tó (Abádszalóki-öböl) & 4 & Bodzás J., Kiss Á. \\
\hline 2007.02.24-25. & Pilismarót, Duna (Pilismaróti-öböl) & $\begin{array}{l}5 \text { ad. hím }+1 \text { imm. } \\
\text { hím }+1 \text { tojó }\end{array}$ & $\begin{array}{l}\text { Bajor Z., Berényi Zs., Gergely C., Juhász I.; } \\
\text { Kolozsvári K., Benyó G. }\end{array}$ \\
\hline 2007.03 .13 . & Hortobágy, Hortobágyi-halastó (Kondás) & 2 hím +2 tojó & Papp G. \\
\hline 2007.03 .16 . & Hortobágy, Hortobágyi-halastó (Kondás) & 4 & Ecsedi Z., Simay A. \\
\hline 2007.03.31. & Hortobágy, Hortobágyi-halastó (Kondás) & 1 tojó & $\begin{array}{l}\text { Bodor G., Horváth G., Kóta A., Selmeczi } \\
\text { Kovács A.. }\end{array}$ \\
\hline 2007.04 .06 & Siófok, Töreki-halastavak & 2 hím & Visnyei M., Illés G., Pálinkás A. \\
\hline
\end{tabular}

\subsection{Pehelyréce (Somateria mollissima)}

Csak néhány előfordulása vált ismertté. Szeptember közepén a Velencei-tavon, majd a Sumonyi-halastavon láttak egy-egy fiatal madarat. Októberi és novemberi adatai a Baaltonról származnak, nem kizárt, hogy ugyanazt a fiatal példányt látták Szántódnál és Fenékpusztánál is.

\begin{tabular}{|c|c|c|c|}
\hline 2006.09 .14 & Gárdony, Velencei-tó & 1 juv. & Albert L. \\
\hline 2006.09 .20 & Sumony, Sumonyi-halastó & 1 juv. hím & Ónodi M. \\
\hline $2006.10 .07-08$. & Szántód, Balaton & 1 juv. hím & $\begin{array}{l}\text { Illés G., Pálinkás A., Kónya A., Jambrich R., } \\
\text { Svéda G., Mészáros A., }\end{array}$ \\
\hline 2006.10 .31 & Fenékpuszta, Balaton & 1 juv. & Cser Sz., Faragó Á., Gál Sz. \\
\hline $2006.11 .06{ }^{*}$ & Fenékpuszta, Balaton & 1 & \\
\hline
\end{tabular}

\subsection{Jegesréce (Clangula hyemalis)}

Csak néhány helyen fordultak elő magányos példányok vagy 2-4 példányos kisebb csapatok. 2006. december 10-én Tihanynál (Gödrös) 8 példányt láttak. A megfigyelések október legvége, november eleje és március közepe között történtek. A látott madarak egyes helyeken (pl. Tihany, Keszthely) hosszabban idöztek, így ott több alkalommal is észlelték őket. Az adatok legnagyobb része a Balatonról származik, de néhány helyen a Dunán (Kisoroszi, Visegrád, Pilismarót, Esztergom, Neszmély), illetve egy-egy esetben a Hortobágyi-halastavon (2006. december 23.), illetve a kiskunlacházi bányatavakon (2007. január 10.) is előkerült.

$\begin{array}{lll}2006.10 .31 . & \text { Fenékpuszta, Balaton } & 1 \text { ad. tojó } \\ 2006.11 .05 . & \text { Siófok, Balaton } & 1 \\ 2006.11 .09 . & \text { Balatonmáriafürdö, Balaton } & 1 \text { ad. tojó } \\ 2006.11 .10 . & \text { Fenékpuszta, Balaton } & 1 \\ 2006.11 .11 . & \text { Keszthely, Balaton (Keszthelyi-öböl) } & 1 \\ 2006.11 .13 . & \text { Keszthely, Balaton (Keszthelyi-öböl) } & 1 \\ 2006.11 .16 . & \text { Siófok, Balaton } & 1 \\ 2006.11 .17 . & \text { Keszthely, Balaton (Keszthelyi-öböl) } & 1 \\ & & \\ 2006.11 .18 . & \text { Tihany, Balaton (Gödrös) } & 4 \\ 2006.11 .19 . & \text { Tihany, Balaton } & 1 \\ 2006.11 .19 . & \text { Tihany, Balaton (Gödrös) } & 1 \\ 2006.11 .19-20 . & \text { Keszthely, Balaton (Keszthelyi-öböl) } & 1 \text { juv. tojó }\end{array}$

Cser Sz., Faragó Á., Gál Sz.

Szücs Cs., Fodor A., Lendvai Cs., Hegedüs D.

Cser Sz., Faragó Á., Gál Sz.

Vasuta G.

Szilágyi A., Tar J., Zalai T.

Szeimann P.

Fodor A., Szücs Cs.

Cser Sz., Faragó Á., Gál Sz.; Fodor A., Szücs

Cs.

Korponai G.

Fodor A., Szücs Cs.

Korponai G.

Ampovics Zs., Cser Sz., Domján A., Faragó Á., 


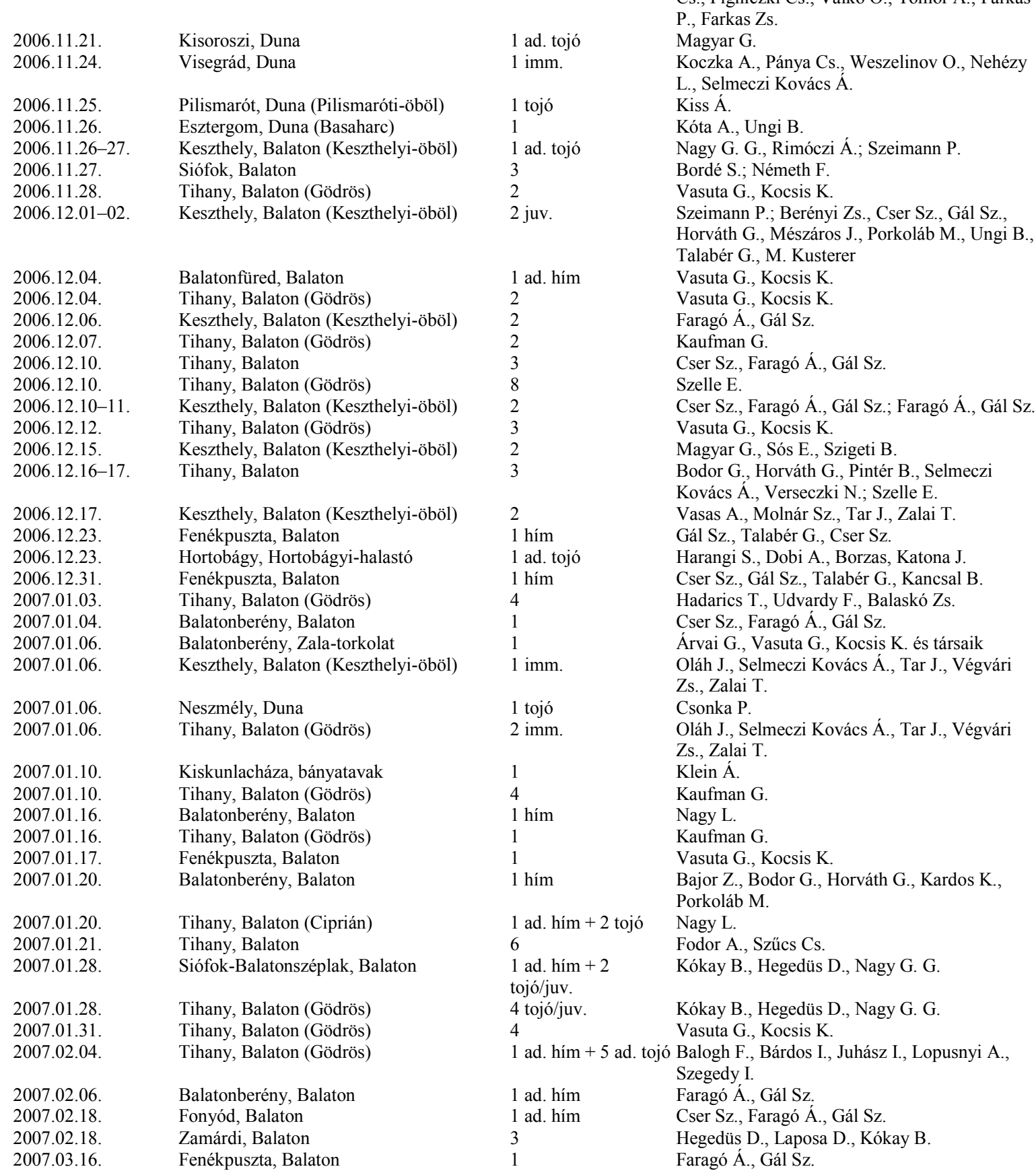

\subsection{Fekete réce (Melanitta nigra)}

November elejétöl december közepétől rendszeresen meg lehetett figyelni 1-3 példányt a Keszthelyi-öbölben (Balaton). December végén a Dunán (Leányfalu) bukkant fel két példány. Összességében a megfigyelések száma és a csapatok nagysága is jóval elmaradt az előző évihez képest.

\begin{tabular}{|c|c|}
\hline 2006.11.06. & Fenékpuszta, Balaton \\
\hline 2006.11.07-08. & Fenékpuszta, Balaton \\
\hline 2006.11.10. & Fenékpuszta, Balaton \\
\hline 2006.11 .19 & Keszthely, Balaton (Keszthelyi-öböl) \\
\hline 2006.11 .21 & Keszthely, Balaton (Keszthelyi-öböl) \\
\hline 2006.11.23. & Keszthely, Balaton (Keszthelyi-öböl) \\
\hline 2006.12 .02 & Keszthely, Balaton (Keszthelyi-öböl) \\
\hline
\end{tabular}

Futó R., Gál Sz., Lisztes A., Németh T., Pánya Cs., Pigniczki Cs., Valkó O.; Tomor Á.; Farkas

Koczka A., Pánya Cs., Weszelinov O., Nehézy meczi Kovacs $A$.

Kóta A., Ungi B.

Sz., Gál Sz., Talabér G., M. Kusterer

Cser Sz, Faragó Á., Gál Sz.; Faragó Á., Gál Sz.

Bodor G., Horváth G., Pintér B., Selmeczi

Cser Sz, Faragó A., Gál Sz.

Oláh J., Selmeczi Kovács Á., Tar J., Végvári

Zs., Zalai T.

Oláh J., Selmeczi Kovács Á., Tar J., Végvári

Zs., Zalai T.

Bajor Z., Bodor G., Horváth G., Kardos K.

Kókay B., Hegedüs D., Nagy G. G.

Faragó Á., Gál Sz.

Hegedüs D., Laposa D., Kókay B.

Faragó A., Gál Sz.

(1) 
2006.12.06. 2006.12.10-11 2006.12.17. 2006.12.29.
Keszthely, Balaton (Keszthelyi-öböl) Keszthely, Balaton (Keszthelyi-öböl) Keszthely, Balaton (Keszthelyi-öböl) Leányfalu, Duna
M. Kusterer

Faragó Á., Gál Sz.

Cser Sz., Faragó Á., Gál Sz.

Vasas A., Molnár Sz., Tar J., Zalai T.

Unicsovics $\mathrm{M}$.

\subsection{Füstös réce (Melanitta fusca)}

Legtöbb adata a Balatonról és a Dunáról származott, de a Tisza-tavon és egyes bányatavakon is megfigyelték. Az első példány október végén jelent meg Fenékpusztánál, és inentől fogva kis számban rendszeresen megfigyelhető volt. Legtöbb adata novemberből és decemberből származott. Általában kisebb, néhány madárból álló csapatokat láttak, tíz vagy annál több példányból álló csapatai a következő alkalmakkor kerültek szem elé: 2006. december 8. Rakaca-víztároló 10 példány, 2006. december 9-10. Balatonaliga és Balatonvilágos 12-13 példány, 2006. december 23. és 2007. január 6. között Fenékpuszta és Balatonberény térsége 27 példány, 2006. december 31. és 2007. február 25. között Balatonvilágos és Balatonaliga térsége 11-33 példány.

2006.10 .31$.
2006.11 .01$.
2006.11 .05
2006.11 .05
2006.11 .05
2006.11 .06$.
2006.11 .07$.
2006.11 .08
2006.11 .09$.
2006.11 .09
2006.11 .10
2006.11 .10$.
2006.11 .10$.
2006.11 .11$.
2006.11 .11$.
2006.11 .11$.
2006.11 .11$.
2006.11 .11$.
2006.11 .13
2006.11 .13
2006.11 .13$.
2006.11 .17
2006.11 .17
2006.11 .18
2006.11 .18

2006.11.19. 2006.11.19. 2006.11.21. 2006.11.21. 2006.11.21.

2006.11.23.

2006.11.24.

2006.11 .25 .

2006.11.25.

2006.11.26.

2006.11.26.

2006.11.27.

2006.11 .27$.

2006.11.27-28.

2006.11.29.

2006.11.30.

2006.12.01.

2006.12 .01 .

2006.12.02.

2006.12.02.

2006.12.02.

2006.12 .03 .

2006.12 .03 .

Fenékpuszta, Balaton
Abádszalók, Tisza-tó (Abádszalóki-öböl)
Siófok, Balaton
Szántód, Balaton
Zamárdi, Balaton
Fenékpuszta, Balaton
Fenékpuszta, Balaton
Fenékpuszta, Balaton
Balatonmáriafürdő, Balaton
Balatonszemes, Balaton
Balatonkenese, Balaton
Fenékpuszta, Balaton
Keszthely, Balaton (Keszthelyi-öböl)
Balatonfenyves, Balaton
Balatonkenese, Balaton
Balatonlelle, Balaton
Fenékpuszta, Balaton
Keszthely, Balaton (Keszthelyi-öböl)
Abádszalók, Tisza-tó (Abádszalóki-öböl)
Neszmély, Duna
Sarud, Tisza-tó (Sarudi-medence)
Keszthely, Balaton (Keszthelyi-öböl)
Pilismarót, Duna (Pilismaróti-öböl)
Abádszalók, Tisza-tó (Abádszalóki-öböl)
Keszthely, Balaton (Keszthelyi-öböl)

Abádszalók, Tisza-tó (Abádszalóki-öböl)

Dunakeszi, Duna

Keszthely, Balaton (Keszthelyi-öböl)

Nyékládháza, bányatavak

Pilismarót, Duna (Pilismaróti-öböl)

Keszthely, Balaton (Keszthelyi-öböl)

Abádszalók, Tisza-tó (Abádszalóki-öböl)

Balatonlelle, Balaton

Nyékládháza, bányatavak

Pilismarót, Duna (Pilismaróti-öböl)

Szántód, Balaton

Badacsonytomaj, Balaton

Pilismarót, Duna (Pilismaróti-öböl)

Dunakeszi, Duna

Fenékpuszta, Balaton

Siófok, Balaton (Ezüstpart)

Abádszalók, Tisza-tó (Abádszalóki-öböl)

Sarud, Tisza-tó (Sarudi-medence)

Balatonaliga, Balaton

Fenékpuszta, Balaton

Pilismarót, Duna (Pilismaróti-öböl)

Abádszalók, Tisza-tó (Abádszalóki-öböl)

Dunakeszi, Duna
Cser Sz., Faragó Á., Gál Sz.

Zalai T.

Szücs Cs., Fodor A., Lendvai Cs., Hegedüs D.

Szücs Cs., Fodor A., Lendvai Cs., Hegedüs D.

Illés G., Pálinkás A., Fáklya B.

Paprika A., Benke Sz., Szeimann P.

Faragó Á., Gál Sz.

Vasuta G., Paprika A.

Cser Sz., Faragó Á., Gál Sz.

Cser Sz., Faragó Á., Gál Sz.

Cser Sz., Faragó Á., Gál Sz.

Vasuta G.

Cser Sz., Faragó Á., Gál Sz.

Németh F.

Szilágyi A., Tar J., Zalai T.

Tar J., Zalai T.

Szilágyi A., Tar J., Zalai T.

Szilágyi A., Tar J., Zalai T.

Zalai T.

Csonka P

Zalai T.

Cser Sz., Faragó Á., Gál Sz.

Hunyadi L.

Kiss Á., Szepesváry Cs., Bodzás J. S

Ampovics Zs., Cser Sz., Domján A., Faragó Á. Futó R., Gál Sz., Lisztes A., Németh T., Pánya Cs., Pigniczki Cs., Valkó O.

Rimóczi Á.

Forintos N.

Szeimann P.

Simay G.

Magyar G.

Ampovics Zs.

Simay A., Simay G., Tihanyi G.

Kovács Gy.

Kovács I., Selmeczi Kovács Á.

Kóta A., Ungi B.

Mészáros J., Barna M., Takács Á.

Árvai G.

Selmeczi Kovács Á.

Selmeczi Kovács Á., Potyó I.; Forintos N.

Vasuta G., Kocsis K.

Illés G., Pálinkás A.

Oláh J., Zalai T.

Zalai T.

Berényi Zs., Horváth G., Porkoláb M., Ungi B., M. Kusterer

Berényi Zs., Cser Sz., Gál Sz., Horváth G.

Mészáros J., Porkoláb M., Ungi B., Talabér G.,

M. Kusterer

Szolnyik R., Szolnyik Cs.

Bodzás J., Rimóczi Á.

Fodor A., D. Bastaja 


\begin{tabular}{|c|c|c|c|}
\hline 2006.12 .05 & Abádszalók, Tisza-tó (Abádszalóki-öböl) & 6 & Rimóczi Á., Nagy G. G. \\
\hline 2006.12 .06 & Nyergesújfalu, Duna (Nyerges-sziget) & 1 & Csonka P. \\
\hline 2006.12 .08 & Abádszalók, Tisza-tó (Abádszalóki-öböl) & 6 & Borbáth P. \\
\hline 2006.12 .08 & Szalonna, Rakaca-víztároló & 10 & Huber A., Farkas R. \\
\hline 2006.12 .09 & Balatonaliga, Balaton & 13 & $\begin{array}{l}\text { Hegedüs D., Kókay B., Laposa D., Gulyás K. } \\
\text { Cs. }\end{array}$ \\
\hline 2006.12 .09 . & Balatonmáriafürdő, Balaton & 3 & Cser Sz., Faragó Á., Gál Sz. \\
\hline 2006.12.09. & Siófok, Balaton & 2 & $\begin{array}{l}\text { Cser Sz., Faragó Á., Gál Sz., Illés G., Pálinkás } \\
\text { A. }\end{array}$ \\
\hline 2006.12 .09 & Zamárdi, Balaton & 4 & Cser Sz., Faragó Á., Gál Sz. \\
\hline 2006.12 .10 & Abádszalók, Tisza-tó (Abádszalóki-öböl) & 6 & $\begin{array}{l}\text { Bodor G., Horváth G., Kóta A., Porkoláb M., } \\
\text { Ungi B. }\end{array}$ \\
\hline 2006.12 .10 & Balatonvilágos, Balaton & 12 & Cser Sz., Faragó Á., Gál Sz. \\
\hline 2006.12 .10 & Csopak, Balaton & 1 & Cser Sz., Faragó Á., Gál Sz. \\
\hline 2006.12 .10 . & Fenékpuszta, Balaton & 5 & Cser Sz., Faragó Á., Gál Sz. \\
\hline 2006.12 .10 . & Tihany, Balaton & 4 & Cser Sz., Faragó Á., Gál Sz. \\
\hline 2006.12 .11 & Fenékpuszta, Balaton & 6 & Faragó Á., Gál Sz.; Vasuta G., Kocsis K. \\
\hline 2006.12 .11 & Nyékládháza, bányatavak & 2 & Simay G. \\
\hline 2006.12 .11 & Siófok, Balaton & 1 & Vasuta G., Kocsis K. \\
\hline 2006.12 .12 . & Balatonvilágos, Balaton & 2 & Vasuta G., Kocsis K. \\
\hline 2006.12 .14 . & Pilismarót, Duna (Pilismaróti-öböl) & 3 & Kiss Á., Szél L. \\
\hline 2006.12.20. & Balatonaliga, Balaton & 6 & Gyüre P., Török H. A., Weszelinov O. \\
\hline 2006.12.22-24. & Pilismarót, Duna (Pilismaróti-öböl) & 3 juv. & $\begin{array}{l}\text { Gránicz L., Forintos N.; Selmeczi Kovács Á.; } \\
\text { Bodor G., Horváth G., Lendvai Cs. }\end{array}$ \\
\hline 2006.12 .23 & Balatonaliga, Balaton & 7 & Mészáros J., Barna M. \\
\hline 2006.12 .23 & Fenékpuszta, Balaton & 27 & Gál Sz., Talabér G., Cser Sz. \\
\hline 2006.12 .25 & Keszthely, Balaton (Keszthelyi-öböl) & 6 tojó/juv. & Sós E. \\
\hline 2006.12 .27 & Pilismarót, Duna (Pilismaróti-öböl) & 3 juv. & Pintér B., Selmeczi Kovács Á. \\
\hline 2006.12 .28 & Pilismarót, Duna & 3 & Kiss B., Vízkert A., Vízkert P., Kiss B. \\
\hline 2006.12 .30 & Pilismarót, Duna (Pilismaróti-öböl) & 3 juv. & Szolnyik Cs. \\
\hline 2006.12 .31 & Balatonberény, Zala-torkolat & 27 & Cser Sz., Gál Sz., Talabér G., Kancsal B. \\
\hline 2006.12 .31 & Balatonvilágos, Balaton & 15 tojó/juv. & Magyar G., Schmidt A., Sós E. \\
\hline 2006.12 .31 & Szob, Duna & 3 & Fodor A., Riezing N., Szeimann P. \\
\hline 2007.01.01. & Baja, Duna & 1 & Kempl Zs. \\
\hline $2007.01 .02-03$. & Pilismarót, Duna (Pilismaróti-öböl) & $3 \mathrm{imm}$. & $\begin{array}{l}\text { Takács Á.; Hadarics T., Udvardy F., Balaskó } \\
\text { Zs. }\end{array}$ \\
\hline 2007.01.04. & Balatonberény, Balaton & 5 & Cser Sz., Faragó Á., Gál Sz. \\
\hline $2007.01 .05-08$. & Pilismarót, Duna (Pilismaróti-öböl) & $3 \mathrm{imm}$. & $\begin{array}{l}\text { Selmeczi Kovács Á.; Bodor G., Horváth G., } \\
\text { Porkoláb M.; Verseczki N., Pintér B., Ungi B. }\end{array}$ \\
\hline 2007.01 .06 & Balatonaliga, Balaton & 6 & $\begin{array}{l}\text { Oláh J., Selmeczi Kovács Á., Tar J., Végvári } \\
\text { Zs., Zalai T. }\end{array}$ \\
\hline 2007.01 .06 & Balatonberény, Balaton & 27 & $\begin{array}{l}\text { Oláh J., Selmeczi Kovács Á., Tar J., Végvári } \\
\text { Zs., Zalai T. }\end{array}$ \\
\hline 2007.01 .06 & Balatonberény, Zala-torkolat & 20 & Árvai G., Vasuta G., Kocsis K. és társaik \\
\hline 2007.01 .06 . & Fenékpuszta, Balaton & 4 & Árvai G., Vasuta G., Kocsis K. és társaik \\
\hline 2007.01 .07 & Balatonvilágos, Balaton & 9 & Fodor A., Barkóczi Cs., Gyarmati G. \\
\hline 2007.01 .09 & Nyergesújfalu, Duna (Nyerges-sziget) & 2 & Csonka P. \\
\hline 2007.01 .11 & Balatonszentgyörgy, Balaton & 1 & Mészáros Cs. és társai. \\
\hline 2007.01 .11 & Szántód, Balaton & 6 & Mészáros Cs. és társai. \\
\hline 2007.01 .13 & Balatonlelle, Balaton & 2 & Kovács Gy. \\
\hline 2007.01 .13 & Pilismarót, Duna (Pilismaróti-öböl) & $3 \mathrm{imm}$. & MME Budapesti HCs \\
\hline 2007.01 .15 & Abádszalók, Tisza-tó (Abádszalóki-öböl) & 2 & Zalai T. \\
\hline 2007.01 .15 & Pilismarót, Duna (Pilismaróti-öböl) & $3 \mathrm{imm}$. & Pintér B., Selmeczi Kovács Á. \\
\hline 2007.01 .16 & Balatonaliga, Balaton & 3 & Pánya Cs. \\
\hline 2007.01.20. & Abádszalók, Tisza-tó (Abádszalóki-öböl) & 2 & Zalai T. \\
\hline 2007.01.20. & Balatonaliga, Balaton & 11 & $\begin{array}{l}\text { Bajor Z., Bodor G., Horváth G., Kardos K., } \\
\text { Porkoláb M. }\end{array}$ \\
\hline 2007.01.20. & Balatonberény, Balaton & 2 & Cser Sz., Gál Sz., Talabér G. \\
\hline 2007.01.20. & Keszthely, Balaton (Keszthelyi-öböl) & 4 & Cser Sz., Gál Sz., Talabér G. \\
\hline 2007.01 .21 & Balatonvilágos, Balaton & 15 & Kókay B., Szücs Cs., Fodor A. \\
\hline 2007.01 .28 & Balatonaliga, Balaton & 8 & Kókay B., Hegedüs D., Nagy G. G. \\
\hline 2007.01.28. & Pilismarót, Duna (Pilismaróti-öböl) & 4 & Kiss Á. \\
\hline 2007.01 .28 & Siófok-Balatonszéplak, Balaton & 1 & Kókay B., Hegedüs D., Nagy G. G. \\
\hline 2007.01 .28 & Siófok-Szabadisóstó, Balaton & 6 & Kókay B., Hegedüs D., Nagy G. G. \\
\hline 2007.01 .30 & Balatonaliga, Balaton & 15 & Illés G., Pálinkás A. \\
\hline 2007.01.31. & Abádszalók, Tisza-tó (Abádszalóki-öböl) & 1 & Gődér R., Rimóczi Á. \\
\hline 2007.01 .31 & Balatonaliga, Balaton & 25 & Vasuta G., Kocsis K. \\
\hline 2007.01 .31 & Pilismarót, Duna (Pilismaróti-öböl) & 4 & Szolnyik Cs. \\
\hline 2007.02 .03 & Balatonaliga, Balaton & 1 & Mészáros J. \\
\hline 2007.02 .04 & Balatonvilágos, Balaton & 21 & $\begin{array}{l}\text { Fodor A., D. Bastaja, Szücs Cs., Bárdos I., } \\
\text { Juhász I., Szegedy I. és mások }\end{array}$ \\
\hline 2007.02 .04 & Nyékládháza, bányatavak & 2 & Simay A., Simay G. \\
\hline 2007.02 .05 & Abádszalók, Tisza-tó (Abádszalóki-öböl) & 4 & Zalai T. \\
\hline 2007.02 .06 & Pilismarót, Duna (Pilismaróti-öböl) & 4 & Laposa D. \\
\hline 2007.02 .06 & Szigliget, Balaton & 1 & Árvai G. \\
\hline 2007.02.10. & Pilismarót, Duna (Pilismaróti-öböl) & 4 & Bak O., Nagy V., Kolozsvári K. \\
\hline
\end{tabular}




\begin{tabular}{|c|c|c|c|}
\hline 2007.02 .16 & Baja, Duna & 1 juv. & Agócs P., Tamás Á. \\
\hline 2007.02 .17 & Balatonaliga, Balaton & 33 & $\begin{array}{l}\text { Svéda G., Jakus L., Szatori J., Konkoly A., Illés } \\
\text { G. }\end{array}$ \\
\hline 2007.02 .18 & Balatonvilágos, Balaton & 28 & Hegedüs D., Laposa D., Kókay B. \\
\hline 2007.02 .18 & Pilismarót, Duna (Pilismaróti-öböl) & 4 & Fodor A. \\
\hline 2007.02 .18 & Zamárdi, Balaton & 1 & Hegedüs D., Laposa D., Kókay B. \\
\hline 2007.02 .20 & Pilismarót, Duna (Pilismaróti-öböl) & 2 & Hunyadi L. \\
\hline 2007.02 .25 & Balatonaliga, Balaton & 32 & Urbán G., Katona I., Kóta A., Kókay B. \\
\hline 2007.03 .09 . & Pilismarót, Duna (Pilismaróti-öböl) & 4 & Balogh F., Szegedy I. \\
\hline 2007.03 .15 . & Nyékládháza, bányatavak & 1 & Szabó A. \\
\hline 2007.03 .16 . & Balatonberény, Balaton & 4 & Faragó Á., Gál Sz. \\
\hline 2007.03 .16 . & Dusnok, Duna & 1 ad. tojó & Agócs P., Kiss T., Baranyai B., Tamás Á. \\
\hline 2007.03 .25 . & Pilismarót, Duna (Pilismaróti-öböl) & 4 hím & Magyar G. \\
\hline
\end{tabular}

\subsection{Csuklyás bukó (Mergus cucullatus)}

A 2005 decemberében és 2006 januárjában a Bősárkány melletti élőhely-rekonstrukciós területen (Nyirkai-Hany) látott nászruhás csuklyás bukó ismét megjelent ugyanazon a területen 2007 februárjában. Az adatot a Nomenclator Bizottság $\mathrm{D}_{\mathrm{E}}$ kategóriásnak fogadta el, azaz a bizottság a madár eredetét bizonytalannak ítélte, mégpedig úgy, hogy a fogságból való szökés valószínübb a vad eredetnél.

$\begin{array}{llll}2007.02 .02 . & \text { Bősárkány, Nyirkai-Hany } & 1 \text { hím }\left(\mathrm{D}_{\mathrm{E}}\right) & \text { R. Kvetko } \\ \text { 2007.02.14. } & \text { Bősárkány, Nyirkai-Hany } & 1 \text { ad. hím }\left(\mathrm{D}_{\mathrm{E}}\right) & \text { Mogyorósi S. } \\ 2007.02 .17 & \text { Bősárkány, Nyirkai-Hany } & 1 \text { ad. hím }\left(\mathrm{D}_{\mathrm{E}}\right) & \text { Ferenczi M., Kozma L., Tomor Á., Király L. }\end{array}$

\subsection{0. Örvös bukó (Mergus serrator)}

Összel az első példányok október végén jelentek meg. Legtöbb adata novemberből és decemberből származott. Az adatok nagy része a Balatonról és a Dunáról származott. Általában fiatal vagy tojó színezetü példányokat láttak, többnyire egy vagy két példányt egyszerre, de három vagy négy madár is több alkalommal szem elé került. 2006. decmber 23-án Zamárdinál 6 példányt figyeltek meg. A tavaszi vonulás során áprilisban Paksnál a Dunán és a Tisza-tavon, májusban pedig a királyszentistváni szennyvíztavakon, illetve az apaji halastavakon látták.

\begin{tabular}{|c|c|c|c|}
\hline 2006.10 .26 & Balmazújváros, Virágoskúti-halastó & 2 & Simay A., Simay G. \\
\hline 2006.10.31-11.01. & Pilismarót, Duna (Pilismaróti-öböl) & 1 tojó & $\begin{array}{l}\text { Laposa D.; Bajor Z., Bodor G., Horváth G., } \\
\text { Porkoláb M. }\end{array}$ \\
\hline 2006.11 .02 . & Pilismarót, Duna (Pilismaróti-öböl) & 2 ad. tojó & Szegedy I. \\
\hline 2006.11 .04$. & Pilismarót, Duna (Pilismaróti-öböl) & 3 & Magyar G. \\
\hline 2006.11 .04$. & Szeged, Fehér-tó & 5 & Nagy T. és társai \\
\hline 2006.11 .08 . & Pilismarót, Duna (Pilismaróti-öböl) & 1 & Magyar G. \\
\hline 2006.11 .10 . & Fenékpuszta, Balaton & 5 & Cser Sz., Faragó Á., Gál Sz. \\
\hline 2006.11 .10 . & Sarud, Tisza-tó (Sarudi-medence) & 4 & Tar J., Zalai T. \\
\hline 2006.11 .11$. & Pilismarót, Duna (Pilismaróti-öböl) & 3 juv. & Selmeczi Kovács Á.; Mészáros J., Barna M. \\
\hline 2006.11 .11 . & Tihany, Balaton (Gödrös) & 3 & Szilágyi A., Tar J., Zalai T. \\
\hline 2006.11.13. & Keszthely, Balaton (Keszthelyi-öböl) & 1 & Szeimann P. \\
\hline 2006.11 .17$. & Pilismarót, Duna (Pilismaróti-öböl) & 3 & Hegedüs D. \\
\hline 2006.11 .18 & Balatonederics, Balaton & 1 & $\begin{array}{l}\text { Ampovics Zs., Cser Sz., Domján A., Faragó Á., } \\
\text { Futó R., Gál Sz., Lisztes A., Németh T., Pánya } \\
\text { Cs., Pigniczki Cs., Valkó O. }\end{array}$ \\
\hline 2006.11 .18$. & Keszthely, Balaton (Keszthelyi-öböl) & 1 & Árvai G. és társai \\
\hline 2006.11 .19 . & Tihany, Balaton & 2 & Fodor A., Szücs Cs. \\
\hline 2006.11 .19 . & Tömörkény, Csaj-tó & 1 tojó/juv. & Bede Á., Öze P. \\
\hline 2006.11 .21 & Keszthely, Balaton (Keszthelyi-öböl) & 3 & Szeimann $\mathrm{P}$. \\
\hline
\end{tabular}




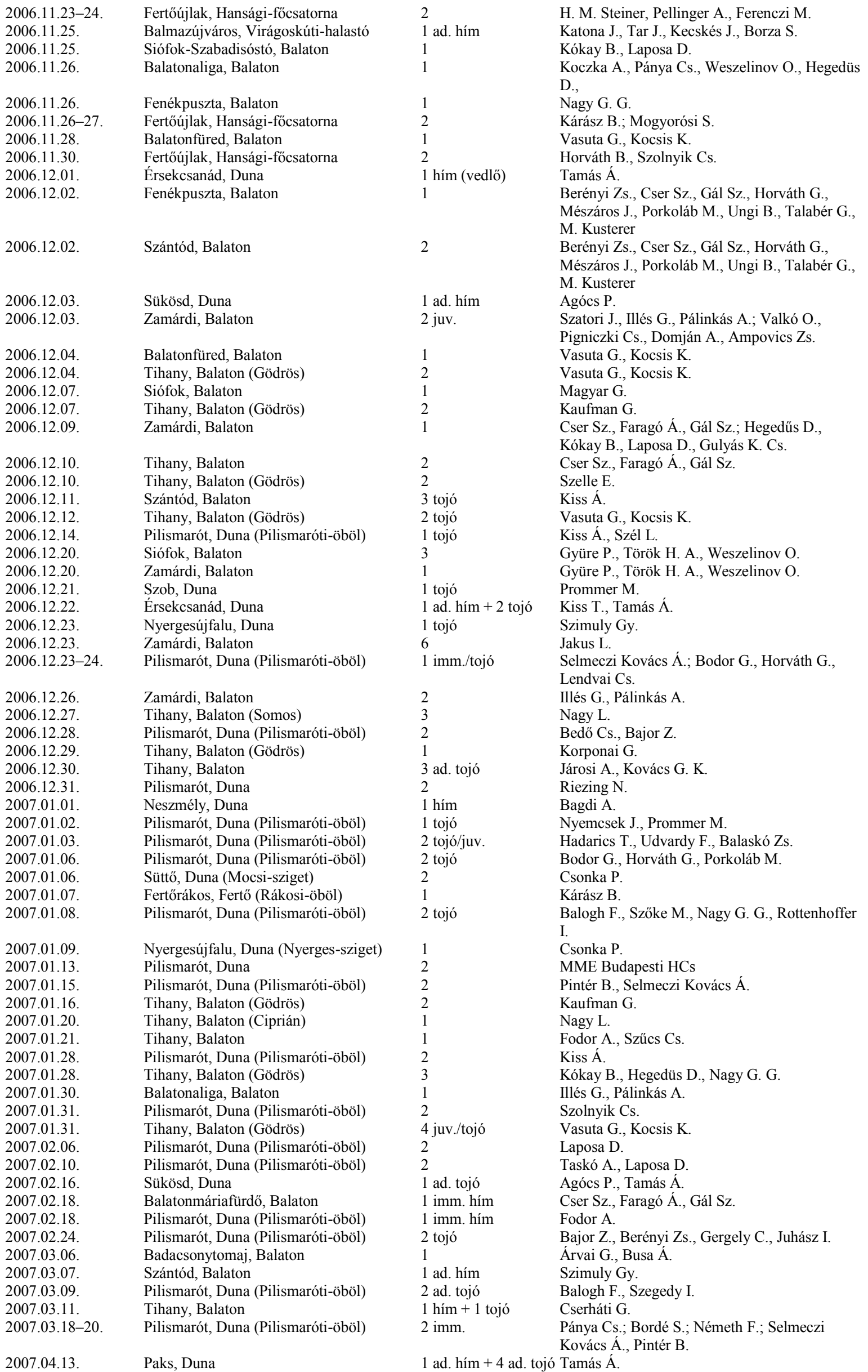




$\begin{array}{llll}2007.04 .23 . & \text { Poroszló, Tisza-tó } & 2 \text { ad. hím }+3 \text { ad. tojó Kovács G., Kovács G. K. } \\ \text { 2007.05.05. } & \begin{array}{l}\text { Királyszentistván, Füzföi Szennyvíz Kft. } \\ \text { utótisztító tava }\end{array} & 1 \text { pár } & \text { Szelle E. } \\ \text { 2007.05.06. } & \text { Apaj, halastavak } & 1 \text { tojó } & \text { Mészáros J., Barna M., Takács Á. } \\ 2007.05 .08 . & \text { Apaj, árasztások } & 1 & \text { Fodor A. }\end{array}$

\section{4. ÖSSZEFOGLALÁS}

A gyakori, és hazánkon nagy tömegben átvonuló fajok vonulásdinamikájának a megismerése szempontjából a havonta egyszer, minden hónap közepén végzett szinkronfelmérések elégnek látszanak, bár nyilván gyakoribb adatgyüjtéssel pontosabb képet kaphatnánk, hiszen elképzelhető, hogy egy-egy faj vonulásának csúcspontja éppen a két felmérés közötti időszakra esik (sokszor napok alatt is jelentös mennyiségi változások lehetnek a madarak számában).

A hazánkban ritkábban megjelenő madárfajok vonulásdinamikája a havi egy felméréssel már nem rajzolódik ki teljesen, hiszen minél ritkább egy faj, annál kisebb a valószínüsége, hogy éppen a szinkronnapokon kerül szem elé. E közlemény tartalmazza a vízivad-monitoring körébe bevont, de Magyarországon ritka, vagy közepesen ritka fajok valamennyi ismertté vált - a www.birding.hu honlapra feltöltött - adatát, mintegy kiegészítve ezen fajok vonatkozásában a már megjelent szinkroneredményeket. Természetesen ezek az adatsorok a gyakori fajok szinkronadataival nem vethetők össze, de az adott madárfaj vonulásáról hűbb képet rajzolnak.

\section{IRODALOM}

EÖRI D. (2010): A kis kárókatona (Phalacrocorax pygmeus) státusza, védelmi lehetöségei Magyarországon. Szakdolgozat. Nyugat-magyarországi Egyetem, Erdőmérnöki Kar, Vadgazdálkodási és Gerinces Állattani Intézet, Sopron. $60 \mathrm{p}$.

FARAGÓ S. (1995): Geese in Hungary. Numbers, migration and hunting bags. IWRB, Slimbridge, 97 p.

FARAGÓ S. (1996): A Magyar Vadlúd Adatbázis 1984-1995: egy tartamos monitoring. Magyar Vízivad Közlemények 2., p. 3-168.

FARAGÓ S. (1998a): A magyar vízivad monitoring eredményei az 1996/1997-es idényben. Magyar Vizivad Közlemények 4., p. 61-262.

FARAGÓ S. (1998b): A vadlúd monitoring eredményei az 1996/1997-es idényben Magyarországon. Magyar Vízivad Közlemények 4., p. 17-60.

FARAGÓ S. (1999a): A magyar vízivad monitoring eredményei az 1997/1998-as idényben. Magyar Vizivad Közlemények 5., p. 63-327.

FARAGÓ S. (1999b): A vadlúd monitoring eredményei az 1996/1997-es idényben Magyarországon. Magyar Vízivad Közlemények 5., p. 3-62.

FARAGÓ S. (2001a): A magyar vízivad monitoring eredményei az 1998/1999-es idényben. Magyar Vízivad Közlemények 7., p. 41-212.

FARAGÓ S. (2001b): A vadlúd monitoring eredményei az 1998/1999-es idényben Magyarországon. Magyar Vízivad Közlemények 7., p. 3-40.

FARAGÓ S. (2002a): A magyar vízivad monitoring eredményei az 2000/2001-es idényben. Magyar Vízivad Közlemények 9., p. 47-249.

FARAGÓ S. (2002b): A vadlúd monitoring eredményei az 1999/2000-es idényben Magyarországon. Magyar Vizivad Közlemények 8., p. 3-43.

FARAGÓ S. (2002c): A vadlúd monitoring eredményei a 2000/2001-es idényben Magyarországon. Magyar Vizivad Közlemények 9., p. 3-45.

FARAGÓ S. (2005a): A magyar vízivad monitoring eredményei a 2002/2003-as idényben. Magyar Vízivad Közlemények 12., p. 43-224.

FARAGÓ S. (2005b): A vadlúd monitoring eredményei a 2002/2003-as idényben Magyarországon. Magyar Vizivad Közlemények 12., p. 3-42.

FARAGÓ S. (2006a): A magyar vízivad monitoring eredményei a 2003/2004-es idényben. Magyar Vízivad Közlemények 13., p. 41-214.

FARAGÓ S. (2006b): A vadlúd monitoring eredményei a 2003/2004-es idényben Magyarországon. Magyar Vizivad Közlemények 13., p. 3-39.

FARAGÓ S. (2007a): A magyar vízivad monitoring eredményei a 2004/2005-ös idényben. Magyar Vízivad Közlemények 14., p. 41-209.

FARAGÓ S. (2007b): A magyar vízivad monitoring eredményei a 2005/2006-os idényben. Magyar Vízivad Közlemények 15., p. 47-220. 
FARAGÓ S. (2007c): A vadlúd monitoring eredményei a 2004/2005-ös idényben Magyarországon. Magyar Vizivad Közlemények 14., p. 3-40.

FARAGÓ S. (2007d): A vadlúd monitoring eredményei a 2005/2006-os idényben Magyarországon. Magyar Vizivad Közlemények 15., p. 3-45.

FARAGÓ S. (2008a): A magyar vízivad monitoring eredményei a 2006/2007-es idényben. Magyar Vízivad Közlemények 17., p. 44-214.

FARAGÓ S. (2008b): A vadlúd monitoring eredményei a 2006/2007-es idényben Magyarországon. Magyar Vizivad Közlemények 17., p. 3-42.

FARAGÓ S. \& GOSZTONYI L. (2002): A magyar vízivad monitoring eredményei az 1999/2000-es idényben. Magyar Vizivad Közlemények 8., p. 45-256.

FARAGÓ S. \& GoszTONYI L. (2003a): A magyar vízivad monitoring eredményei az 2001/2002-es idényben. Magyar Vizivad Közlemények 11., p. 51-252.

FARAGÓ S. \& GOSZTONYI L. (2003b): A vadlúd monitoring eredményei a 2001/2002-es idényben Magyarországon. Magyar Vízivad Közlemények 11., p. 3-50.

FARAGÓ S. \& JÁNOSKA F. (1996): A vadlúd monitoring eredményei az 1995/1996-os idényben Magyarországon. Magyar Vizivad Közlemények 2., p. 169-212.

HADARICS T. (2000): Ritkább vízivadfajok előfordulása Magyarországon az 1997/1998-as vonulási idényben. Magyar Vizivad Közlemények 6., p. 207-258.

HADARICS T. (2003a): Ritkább vízivadfajok előfordulása Magyarországon az 1998/1999-es vonulási idényben. Magyar Vizivad Közlemények 10., p. 141-195.

HADARICS T. (2003b): Ritkább vízivadfajok előfordulása Magyarországon az 1999/2000-es vonulási idényben. Magyar Vizivad Közlemények 10., p. 197-263.

HADARICS T. (2008): Új fajok a Fertő madárfaunájában 1996 és 2003 között. Szélkiáltó 12., p. $23-27$.

HADARICS T. (2013): Ritkább vízivadfajok előfordulása Magyarországon a 2001/2002-es, a 2002/2003-as és a 2003/2004-es idényben. Magyar Vízivad Közlemények 23., p. 121-143.

HADARICS T. (2016): Ritkább vízivadfajok előfordulása Magyarországon a 2004/2005-ös vonulási idényben.

Magyar Vizivad Közlemények 28., in press http://dx.doi.org/10.17242/MVvK 28.05

HADARICS T. (2016): Ritkább vízivadfajok előfordulása Magyarországon a 2005/2006-os vonulási idényben.

Magyar Vizivad Közlemények 28., in press http://dx.doi.org/10.17242/MVvK 28.06

Selmeczi KovÁcs Á. (2014): Az énekes hattyú (Cygnus cygnus) fészkelése Magyarországon 2005-2011. Szélkiáltó 16., p. 3-4.

VASUTA G. (2006): Jeges búvár Tihanynál. Napló 62. (295.), p. 12. 


\title{
THE OCCURRENCE OF RARE WATERFOWL SPECIES IN HUNGARY DURING THE 2006/2007 MIGRATION
}

\author{
Hadarics, T.
}

\section{SUMMARY}

The synchronous surveys conducted once in the middle of every month seem to be sufficient to describe the dynamics of migration of the species that frequently and in large numbers migrate trough Hungary. It is clear, though that we could get a more precise picture by the use of more frequent data collection since it is possible that the peak of a given species occurs in the period between two subsequent surveys (there often may be significant changes in the number of birds in a couple of days).

The dynamics of migration of rare species cannot be precisely given with the monthly survey because the rarer the species, the less likely it can be seen during synchronous days. This report contains all the data of the rare and moderately rare species in Hungary covered by waterbird monitoring that can be found in the data base of the web page www.birding.hu, there by supplementing the already published synchronous results of these species. Naturally these data cannot be compared with the synchronous data of frequent species, but they still give a somewhat better view of the migration of the given species.

During the 2006/2007 synchronous survey season the following rare species were observed. At the not genuine wild origin species the category $\left(C, D_{A}, D_{E}\right.$ or $\left.E\right)$ is given in brackets.

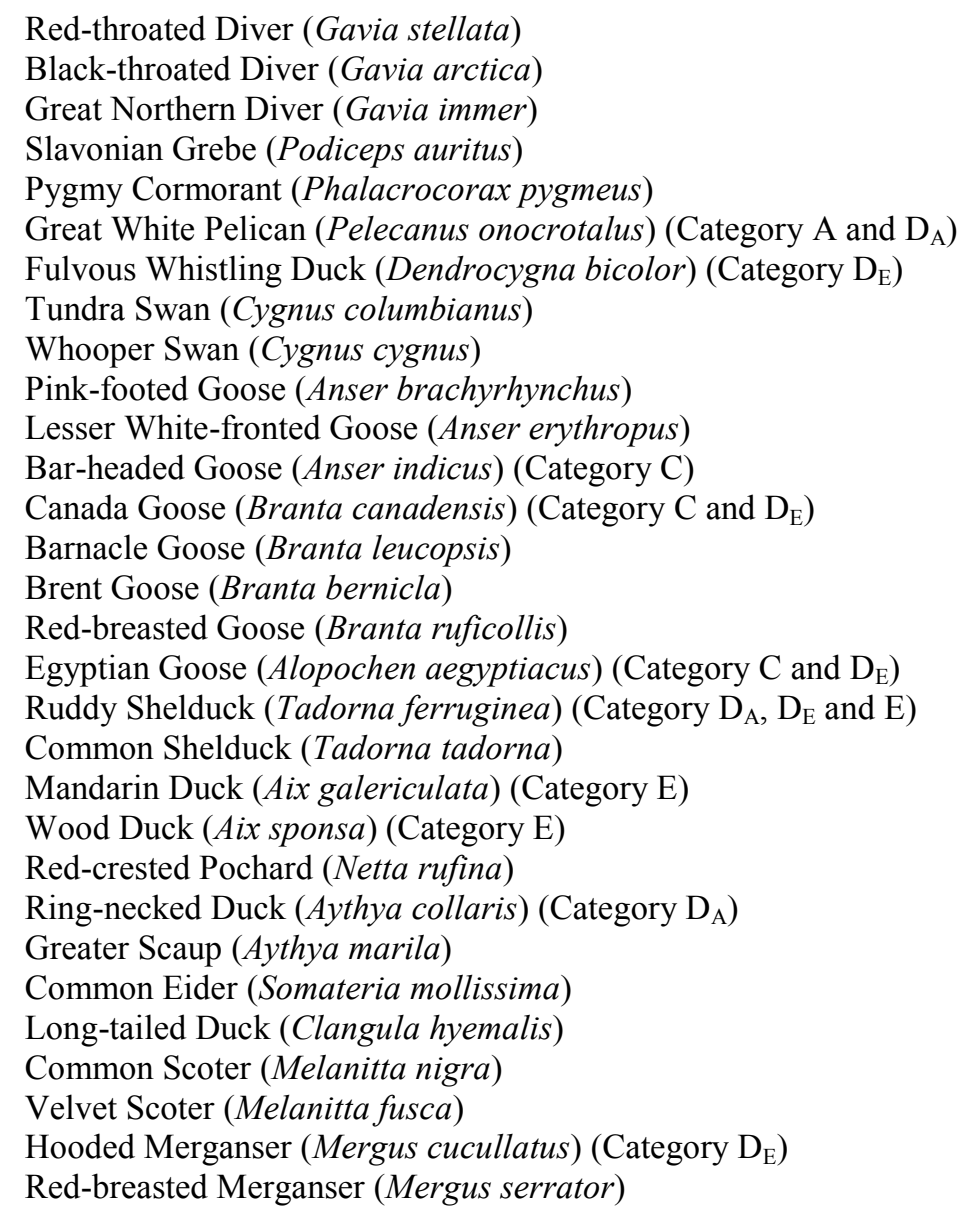

During the study period 30 rare or moderately rare waterbird species were observed. Unlike the previous season the Snow Goose and the Blue-winged Teal did not occur. By contrast six species were not noticed in previous season, the Great Northern Diver, the Great White Pelican, the Fulvous Whistling Duck, the Pink-footed Goose, the Canada Goose, and the Ring-necked Duck. The Fulvous Whistling Duck occured in Hungary for the first time (Category $\mathrm{D}_{\mathrm{E}}$ ). Among the scarce and rare species the Pygmy Cormorant, the Redbreasted Goose, the Common Shelduck, the Red-crested Pochard were the most frequent. The Great Northern Diver (Category A), the Great White Pelican (Category A and $\mathrm{D}_{\mathrm{A}}$ ), the Tundra Swan (Category A), the Pinkfooted Goose (Category A), the Bar-headed Goose (Category C), the Canada Goose (category C and $\mathrm{D}_{\mathrm{E}}$ ), the 
Brent Goose (Category A), the Egyptian Goose (Category C and $\mathrm{D}_{\mathrm{E}}$ ), the Mandarin Duck (Category E), the Wood Duck (Category E), the Ring-necked Duck (Category $\mathrm{D}_{\mathrm{A}}$ ), the Common Eider (Category A) and the Hooded Merganser (Category $\mathrm{D}_{\mathrm{E}}$ ) were represented with minimal numbers. The details of records can be seen in the Hungarian text. 
